\title{
Interests, Norms, and Support for the Provision of Global Public Goods: The Case of Climate Cooperation*
}

\author{
Michael M. Bechtel ${ }^{\dagger} \quad$ Federica Genovese ${ }^{\ddagger} \quad$ Kenneth F. Scheve ${ }^{\S}$
}

February 9, 2017

Mitigating climate change requires countries to provide a global public good. This means that the domestic cleavages underlying mass attitudes toward international climate policy are a central determinant of its provision. We argue that the industry-specific costs of emission abatement and internalized social norms help explain support for climate policy. To evaluate our predictions we develop novel measures of industry-specific interests by cross-referencing individuals' sectors of employment and objective industry-level pollution data and employing quasi-behavioral measures of social norms in combination with both correlational and conjoint-experimental data. We find that individuals working in pollutive industries are 7 percentage points less likely to support climate cooperation than individuals employed in cleaner sectors. Our results also suggest that reciprocal and altruistic individuals are about 10 percentage points more supportive of global climate policy. These findings indicate that both interests and norms function as complementary explanations that improve our understanding of individual policy preferences.

*We thank Lisa Martin, Emilie Hafner-Burton, and seminar participants at the American Political Science Association Meetings 2014, International Political Economy Society Conference 2014, the University of Konstanz, and UCSD for helpful comments. We gratefully acknowledge financial support from the Swiss Network for International Studies, Yale University's MacMillan Center for International \& Area Studies, Yale University's Institution for Social and Policy Studies, and Stanford University's Department of Political Science. Michael M. Bechtel gratefully acknowledges support from the Swiss National Science Foundation (grant \# PP00P1-139035).

${ }^{\dagger}$ Department of Political Science, Washington University in St.Louis and Swiss Institute for International Economics and Applied Economic Research, St.Gallen, Switzerland, mbechtel.mail@gmail.com.

$\ddagger$ Department of Government, University of Essex, United Kingdom, genovese.federica@gmail.com.

$\S$ Department of Political Science and Freeman Spogli Institute for International Studies, Stanford University, United States, scheve@stanford.edu. 
Addressing the causes and consequences of climate change presents one of the major policy challenges to humankind. Climate change cooperation poses a particular problem because states need to agree on a set of policies internationally that have to be enforced domestically. Yet there exists a strong incentive to free ride on the climate policy efforts of other countries. A potential solution to this problem may stem from the domestic politics of climate policy. If there exists strong enough public support for global climate cooperation in several countries, electoral accountability may motivate policymakers to agree on and domestically enforce mitigation policy objectives. However, while some individuals support climate policy, others remain opposed. What explains domestic disagreement on international climate cooperation? Answering this question can shed light on the path to an effective climate deal that stands a chance of being domestically enforceable (Böhmelt 2013; Cao, Milner, Prakash and Ward 2014; Victor 2006). To the extent that conflict mirrors asymmetries in the expected economic costs of climate mitigation, there may be opportunities to adopt policies that guarantee that the costs and benefits of reducing greenhouse gases are widely shared. To the extent that conflict mirrors differences in social norms, countries may realize effective international climate cooperation by designing policies and institutions in ways consistent with these other-regarding concerns.

Examining the importance of costs and norms in explaining public support for climate policy relates to a classic debate in the social sciences that asks whether actors are motivated primarily by their economic well-being (Becker 1983; Meltzer and Richard 1981; Becker 1975; Olson 1965) or their social values and beliefs (Ostrom 2000; Weber 1968). The debate about whether self-interest or norms explain behavior also characterizes large literatures in political science. For example, international relations theories often emphasize either the role of national interests or the importance of norms (Finnemore and Sikkink 2001; Hopf 1998; Waltz 1979) for explaining international cooperation and conflict. The interests-norms dichotomy also underlies March and Olsen's (1998) distinction between the logic of consequences, according to which actors' choose the policies that they expect to 
maximize their personal well-being, and the logic of appropriateness, which holds that individuals choose actions consistent with their normative beliefs about what constitutes virtuous behavior. The debate about the role of interests and values for our understanding of policy choice continues to structure a diverse set of literatures on the sources of support for free trade (Lü, Scheve and Slaughter 2012; Naoi and Kume 2011; Mansfield and Mutz 2009; Hainmueller and Hiscox 2006; Scheve and Slaughter 2001b), immigration (Malhotra, Margalit and Mo 2013; Hainmueller and Hiscox 2010; Hanson, Scheve and Slaughter 2007; Mayda 2006), and redistributive policy (Gilens 2012; Rehm, Hacker and Schlesinger 2012; Lupa and Pontusson 2011; Alesina and Giuliano 2011; Shayo 2009). These debates share a common feature in that they typically pose the question in either or terms: in one view actors are primarily motivated by their interests while in the other their behavior should be understood as a product of values and deeply held social norms.

Yet in most areas of social and economic life, individuals appear to be motivated by both interests and values. For example, people prefer to make more money than less and to pay less for goods than more, but they also choose careers that they find meaningful at substantial financial sacrifice and shy away from buying goods produced by mistreated workers even though they cost less. Building on this idea, our theory holds that individuals' willingness to back international climate policy efforts depends on both the expected costs resulting from climate mitigation and the social norms individuals hold. We offer a direct empirical evaluation of these arguments using individual-level data and novel measures of key theoretical concepts. We employ correlational and experimental data from original largescale surveys fielded in France, Germany, the United Kingdom and the United States, four developed democracies with a long history of greenhouse gas emissions whose willingness to support mitigation efforts will be crucial for progress in global climate policy.

To study the importance of economic interests and social norms, we develop novel measures of individuals' expected costs of mitigation and quasi-behavioral measures of intrinsic social values. We capture the expected, sector-specific costs of climate cooperation by mea- 
suring the emission levels and the energy intensity of individuals' sectors of employment. To account for social norms we employ behavioral information from payoff-relevant, gametheoretic experiments embedded in our survey. We focus on altruism and reciprocity since the literature on public good provision (Fehr and Fischbacher 2004) and climate policy (Allo and Loureiro 2014; Milinski, Semmann, Krambeck and Marotzke 2006) has repeatedly emphasized their importance in understanding when societies overcome the cooperation problem inherent in climate policy. We use these explanatory variables along with a large set of control variables to examine mass support for international climate policy and related environmental policy outcomes. The results indicate a strong negative partial correlation between the pollutiveness of an individual's industry of employment and support for climate cooperation. Specifically, our estimates imply that belonging to a high environmental impact sector decreases the probability of supporting climate change agreements by 7 percentage points. We also find evidence of a strong positive relationship between being an altruistic or high reciprocity type and support for climate cooperation. Individuals with above the median scores on our quasi-behavioral reciprocity and altruism measures are on average 10 percentage points more likely to support climate cooperation.

We complement these main results with a second set of analyses that rely on data from an experimental climate treaty conjoint study (Bechtel and Scheve 2013). The conjoint design randomly assigned individuals to hypothetical climate agreements with different attributes. We focus on two sets of attributes, one relating to the role of economic interests (monetary costs of the treaty), the other relating to norms of conditional cooperation (international participation in the treaty). We examine how variation on each of these dimensions affects mass support for global climate agreements, and how the findings on the two dimensions are mediated by the sector-based expectations, which is the measure that is fully generated outside of the survey framework. We find that public support is highly sensitive to the costs of alternative climate agreements, but also depends on the extent of conditional cooperation by other countries. To explore whether these sensitivities mirror differences in the expected, 
sector-specific costs caused by stricter climate policy, we examine the treatment effects by our pollution measures. First, we find that respondents working in high-emission industries are significantly more sensitive to the inclusion of sanctions for countries that fail to meet their emission targets. This is consistent with the idea that individuals working in more pollutive industries expect larger sanctions to raise the pressure to meet abatement obligations which, in turn, increases their expected, industry-based costs of joining a climate agreement. Second, we find that the policy opinions of respondents employed in high-emission industries depend less strongly on the extent of participation by other countries. This suggests that interest-based concerns can mitigate the importance of conditional cooperation in climate change opinion.

Overall, our study suggests that economic interests and social norms are both important domestic foundations of support for global governance in wealthy democracies. Although many societies value the potential benefit of participating in international emission abatement, our findings suggest that distributional concerns can limit enthusiasm for mitigation efforts while the presence of social norms can increase support for climate cooperation. Thereby, our study not only extends work on public opinion about climate change (Tvinnereim and Lachapelle 2014; Gampfer, Bernauer and Kachi 2014; Tingley and Tomz 2014; Bechtel and Scheve 2013; Egan and Mullin 2012; Carlsson, Kataria, Krupnick, Lampi, Löfgren, Qin, Chung and Sterner 2012), but more generally indicates the usefulness of paying attention to social norms and interest-based factors as complementary explanations for domestic conflict over the provision of global public goods and mass support for international cooperation. 


\section{The Foundations of Support for Global Climate Pol- icy: Interests and Norms}

Our investigation of the role of interests and norms in guiding individual preferences on climate policy directly relates to a large body of scholarly work on the domestic determinants of international agreements. This research has studied the politics of domestic commitments to international integration (Ward, Grundig and Zorick 2001; von Stein 2008; Hovi, Sprinz and Underdal 2009) as well as the trade-offs between international participation and compliance (Barrett and Stavins 2003; Pittel and Rübbelke 2008) highlighting that the supply of manageable greenhouse gases constitutes a model of environmental public good for which cross-national domestic support is essential (Keohane and Victor 2011).

In a simplified model of climate change policy, societies can decide to either mitigate emissions or continue polluting. Addressing climate change requires costly cooperation since countries have to reduce energy consumption and adopt new technologies to reduce greenhouse gas emissions (Babiker 2005; Urpelainen 2010). While the costs remain ultimately private, the gains from cooperation are public and arise from the collective benefits due to reduced emissions in the form of preserved natural resources and, in the long-run, a stable climate with less frequent and less severe natural disasters. ${ }^{1}$ This creates a freerider problem that countries may potentially overcome if there exists enough domestic support for global climate policy. But which cleavages underlie public opinion on climate cooperation?

\section{Interests: Sector of Employment and Support for Climate Cooper- ation}

We theorize that the domestic distribution of costs and benefits of emission abatement help explain individual support for global climate policy. Clearly, some individuals may remain

\footnotetext{
${ }^{1}$ Certainly, individuals in some places and countries may have more to benefit from reduced emissions than others, but generally most of the world population would benefit from less variability in temperatures and weather patterns (UNEP 2012).
} 
unwilling to contribute to this global public good under any circumstances. For many other, however, losses and gains of cooperation will matter. We argue that two types of factors determine these costs and benefits: Considerations rooted individuals' own positions within the economy as well as internalized social norms they use to assess the normative desirability of policy. These two different types of motivations also tap into March and Olsen's (1998) distinction between the logic of consequences, which highlights the importance of interests in understanding political choice, and the logic of appropriateness according to which actors' make decisions that mirror their normative convictions.

The idea that actors condition their support for a policy on the financial burden this choice entails figures prominently in many theoretical accounts of preferences over public policy. It has been applied to explain attitudes toward immigration (Scheve and Slaughter 2001a), free trade (Scheve and Slaughter 2001b), foreign direct investment (Pandya 2010), financial rescues (Broz 2005), and international redistribution (Bechtel, Hainmueller and Margalit 2014). For example, Gabel (1998) argues that occupation-based interests explain the public divide between those who support European integration and those who oppose it. Similarly, Hanson, Scheve and Slaughter (2007) emphasize the expected fiscal consequences of immigration inflows as an explanation for anti-immigration sentiment.

In the climate change context approving an international agreement will have economic, redistributive consequences if the policy is supposed to be effective. After all, the key objective of global climate cooperation is to reduce greenhouse gas emissions, so the necessary regulatory policies require industries to incur non-trivial adjustment costs in the form of emission reductions or investment in technology. These adjustment costs will have repercussions on firms' profits and, in turn, on individuals' work conditions and salaries.

We start from the assumption that adjustment costs will not be uniformly distributed across sectors. Instead, climate policy entails costs that vary considerably between economic sectors as a function of their levels of emissions (Kolstad 2014; Hoel 1996). The idea of variation in the costs of climate mitigation and adaption efforts also underlies Stokes's (2015) 
argument that the geographic distribution of wind turbines affects electoral choice and thus conflict over energy policy.

We argue that industry-based differences in the costs of abatement help explain support for climate policy. Industries that emit large amounts of greenhouse gases will incur higher adjustment costs than sectors that contribute little to nothing to a country's emissions. While lobbying efforts (Fredriksson, Neumayer and Ujhelyi 2007), temporary differences in

implementation in multi-level systems (Bechtel and Urpelainen 2015), and the benefits of improving production practices may temper these costs to some extent, effective climate change policies will necessarily impose higher costs on 'dirtier' sectors. This affects the relative profitability of sectors that produce large amounts of greenhouse gas emissions compared to industries that only account for a small share of total emissions. Consequently, individuals working in more pollutive industries expect intensified climate regulation to negatively affect their employment situation either in terms of lower wages or in terms of job security. Therefore, we expect that individuals working in sectors that emit large amounts of greenhouse gases should display more opposition to international climate policy efforts than those employed in sectors that produce less greenhouse gases. Vice versa, the lower the pollution intensity of an individual's sector of employment, the lower the anticipated costs of international climate cooperation, hence the higher the support for international climate policy, ceteris paribus.

\section{Social Norms: Reciprocity and Altruism}

A second and complementary set of arguments that may help explain why some citizens support or oppose global climate cooperation originates from work on individuals' willingness to contribute to public goods (Fischbacher, Gächter and Fehr 2001; Ostrom 2000; Camerer and Fehr 2004). This research suggests that individuals often accept the costs from public goods provision because they have internalized social norms that foster cooperation. Two norms that may offer useful explanations in this context are reciprocity and altruism. For 
example, recent work suggests that in the context of climate change, individuals may be more likely to support cutting back on greenhouse gas emissions because of altruistic reasons or to reciprocate other actors' efforts (Milinski et al. 2006). Along similar lines, international relations scholars have argue that norms of other-regardingness matter when countries negotiate climate change agreements (Barrett and Stavins 2003). Therefore, we also concentrate on these two types of social norms - reciprocity and altruism - as they promise to improve our understanding of the conditions under which individuals support global climate policy.

Reciprocity refers to the general willingness to return favors and retaliate unfriendly actions (Fehr and Gächter 2000, 164). When considering a simple, two-player public goods problem, a reciprocity norm would lead an individual to contribute to the public good if she believes the other person will also contribute. ${ }^{2}$ A large lab-experimental literature has demonstrated that reciprocity strongly fosters cooperation in social dilemma situations (Fischbacher and Gächter 2010; Falk and Fischbacher 2006). To effectively combat global warming, countries have to cooperate and accept costly abatement policies in the presence of incentives to freeride on the policy efforts of others. Reciprocity reduces the risk of freeriding because it stabilizes expectations about others' cooperative behavior which fosters the evolution of cooperation. Plausibly, individuals expect at least some, albeit potentially small, nonzero efforts by other countries. While these expectations about the cooperative behavior of others should remain inconsequential in the case of non-reciprocal individuals, we would expect that those embracing a norm of conditional cooperation should be more supportive of international climate cooperation.

Since climate policy constitutes a public good, a second important norm that should increase an individual's willingness to support global climate cooperation is altruism, defined as a general concern for the well-being of other individuals (Camerer and Fehr 2004). Previous work has shown that altruism explains individuals' donations for public causes and the supply of public goods (Fehr and Fischbacher 2003). Consequently, this norm may play

\footnotetext{
${ }^{2}$ Applied to our context, this definition yields more specific predictions than ? understanding of reciprocity as "mutuality in face of disagreement" (p. 14).
} 
an important role for understanding individual preferences for climate policy, because the advantages resulting from emission reductions will benefit all societies including yet unborn generations. While we remain agnostic about the exact origin of individuals' altruistic inclinations, in particular, the extent with which these constitute pure or impure forms of altruism (Andreoni 1990), one would expect that more altruistic individuals will generally be more in favor of international climate cooperation than less altruistic persons.

We note that reciprocity and altruism constitute two distinct, theoretically independent types of social norms. While reciprocity implies that one's own willingness to contribute to a public good depends on the expected behavior of other actors, altruism does not involve such a condition (Fehr and Fischbacher 2005). In other words, both altruistic and non-altruistic individuals could be conditionally cooperative or not. Moreover, one may argue that social norms form part of an individual's general political left-right ideology. For example, as more altruistic convictions could be more widespread among leftist individuals reciprocity, understood as the willingness to contribute to a public good if others also do their share, belongs to a more conservative attitude. While we remain agnostic about whether this is the case, this possibility suggests that one should control for ideology in the part of our analysis that employs observational data.

In what follows we introduce our sector-based measures of economic interests and quasibehavioral measures of norms and evaluate our predictions with the objective of determining how these factors influence support for global climate policy. Afterwards, we present experimental evidence that allows us to further explore the effects of costs and reciprocity features of climate change agreements. 


\section{Correlates of Support for Climate Change Coopera- tion}

We first test our hypotheses using data from original surveys that we fielded in the summer of 2012 in France, Germany, the United Kingdom, and the United States. All four surveys were conducted by YouGov over the internet on representative samples of the adult population. ${ }^{3}$ The sample size was 2,000 for France, Germany, and the United Kingdom and 2,500 for the United States. We begin our analysis by examining the extent to which objective measures of economic interest and quasi-behavioral measures of norms correlate with public opinion about climate cooperation and support for climate policy. In the next section we move to exploring the effects of cost and norm attributes of a climate agreement through a conjoint experiment.

\subsection{Outcome Variables}

Our main outcome variable measures support for international climate change policy. We asked respondents the following question:

"As you probably know, many experts say that countries have to reduce their greenhouse gas emissions to address global warming. Generally speaking, how strongly do you support or oppose international cooperation to reduce greenhouse gas emissions even if this involves significant costs?"

Respondents could answer that they 'strongly oppose' (1), 'somewhat oppose' (2), 'neither oppose nor support' (3), 'somewhat support' (4), or 'strongly support' (5) cooperation. We set the variable Support: Global Climate Cooperation equal to one for those who 'support' or 'strongly support' international climate cooperation, and equal to zero otherwise.

\footnotetext{
${ }^{3}$ YouGov employs an opt-in panel together with matched sampling to approximate a random sample of the adult population (Rivers 2011). Matched sampling involves taking a stratified random sample of the target population and then matching available internet respondents to the target sample. Ansolabehere and Rivers (2013) and Ansolabehere and Schaffner (2013) show that matched sampling also produces accurate population estimates and replicates the correlational structure of random samples using telephones and residential addresses.
} 
International cooperation on environmental issues is multifaceted and respondents may think of different aspects of global climate cooperation. To strengthen the interpretation of our findings based on the Support: Global Climate Cooperation variable, we measured attitudes towards two additional aspects of climate policy: The importance of reducing greenhouse gas emissions and the willingness to incur costs to protect the environment.

The variable Importance of CO2 Reductions provides us with a measure of the priority that respondents attach to carbon abatements. It is based on the following question:

"How important do you think it is for [France, Germany, the United Kingdom, the United States] to reduce greenhouse gas emissions?"

The answers ranged from 0 for 'not at all important' to 10 for 'extremely important."'

The variable Willingness to Pay for the Environment intends to elicit the value of realizing CO2 emissions through individual action with the associated costs being conceptualized relative to a respondent's monthly income. The variable is based on responses to the question:

"If you consider your monthly income, how much of it would you be willing to invest into reducing greenhouse gas emissions (for example, buying energy efficient electric appliances, installing heat insulation in your home, buying electric power produced from renewable energy sources, buying locally produced food)?"

The answers ranged from 0 to $100 \%$, with $0 \%$ meaning 'nothing at all' and $100 \%$ meaning 'my whole income.' While we believe that the level of the Willingness to Pay for the Environment outcome will be inflated, we can still analyze the observable variation to evaluate the empirical relevance of our theoretical arguments.

\subsection{Measuring Sector-Based Interests}

The evaluation of our theoretical argument about the importance of sector-based interests requires a measure of how costly reducing greenhouse gas emissions is likely to be in the sectors in which individuals are employed. This focus necessitates to restrict our analyses to 
individuals that are employed. While this restriction reduces our sample size, it allows us to rely on objective pollution measures to proxy for the expected costs of climate regulation as opposed to subjectively stated economic interests that may be endogenous to climate policy attitudes. Moreover, focusing on employed individuals means to analyze a rather clear set of individuals who are highly politically relevant both in terms of policy preferences and interest group representation.

Our novel sector-based interest variables were measured as follows. We asked those respondents that selected 'paid work' on a simple employment status question to select their sector of employment using the 21 International Standard Industrial Classification (ISIC) categories. ${ }^{4}$ 4,009 respondents identified themselves as workers of one of the 21 sectors $(817$ in France, 929 in Germany, 1,141 in the UK, 1,122 in the US). ${ }^{5}$ We also included a 'none of these' answer for the sectors, which resulted in the respondent having the option of verbally describing her profession. In the Appendix we describe how we qualitatively assessed whether the industry of those individuals that selected this alternative category is identifiable based on their written response.

Based on this information, for each respondent we collected indicators on their industries' objective environmental impact from a number of data sources. Our main industry cost indicator is the Greenhouse Gases (GHG) Emissions variable. This variable measures gross direct emissions in million tons of produced CO2-equivalent gases for the year 2011. We collected the raw figures from the OECD Environmental Statistics database, which follows the GHG concept of the International Panel on Climate Change (IPCC), which is the scientific intergovernmental body of the United Nations Framework Convention on Climate Change. ${ }^{6}$ We prefer this measure over alternative indicators of pollution-based industrial

\footnotetext{
${ }^{4}$ These correspond to the United Nations Statistics Division's International Standard Industrial Classification (ISIC) of All Economic Activities (Revision 4).

${ }^{5}$ In the Appendix we describe how we collected information on each individual's employment and which industry sectors we listed for selection.

${ }^{6}$ According to the IPCC definition, GHG includes natural and human-caused constituents of the atmosphere that absorb and emit radiation. The gases included in the definition are carbon dioxide (CO2), nitrous oxide ( $\mathrm{N} 2 \mathrm{O})$, methane ( $\mathrm{CH} 4)$, plus sulphur hexafluoride (SF6), hydrofluorocarbons (HFCs) and perfluorocarbons (PFCs).
} 
interests because it offers a comprehensive way of capturing industry-specific climate policy costs. More specifically, this variable accounts for emissions from energy use and industrial processes, which mainly produce $\mathrm{CO} 2$, as well as emissions from solid waste, mining and agriculture, which mainly produce methane, in addition to other greenhouse gases. The OECD database aggregates greenhouse gas emissions at the sectoral level for most ISIC categories, albeit not for the service sectors. ${ }^{7}$ To generate an estimate of GHG emissions for the ISIC public service sectors (ISIC 9 to 21) we multiplied the total services emissions by each of the 13 service sectors' share of total value added. ${ }^{8}$ This allows us to generate weighted emissions for service sectors with possibly different environmental 'footprints.'

The GHG Emissions variable captures large differences in emissions across sectors which are relatively similar - in relative terms - in the four countries. For example, in the US, the Transportation sector generated about 1,700 million CO2 equivalent emissions in 2011 (roughly one third of total emissions, according to our calculations). By contrast, the Education sector emits about 8 million emissions (less than 1 percent). To account for measurement error and to relax the functional-form assumptions underlying our estimations we dichotomize the pollution measures by splitting the sectors at the median of their pollution measure distribution within each country. Thus, we convert the GHG emissions variable as well as our alternative pollution measures into binary indicators that take on the value zero for low GHG emissions and equal 1 for high GHG emissions. When matching this information with our individual-level data we find that 2,261 individuals in our sample work in sectors with relatively low greenhouse gas emission, while 1,748 work in sectors with high emissions GHG Emissions: High. ${ }^{9}$ Note that our results are not sensitive to this dichotomization, as using more continuous versions of this measure generates qualitatively similar results (see

\footnotetext{
${ }^{7}$ This is not a feature of the OECD only, but service sectors are generally reported as aggregated. See, for example, the United Nations Industrial Development Organization's Industrial Efficiency Policy Database or the World Bank Indicator Database.

${ }^{8}$ The Appendix provides a detailed description of the coding decisions for the conversion of emissions from the IPCC categories to the ISIC categories.

${ }^{9}$ The numbers by country are: 360 in low emissions and 457 in high emissions for France; 502 in low emissions and 427 in high emissions for Germany; 723 in low emissions and 418 in high emissions for the United Kingdom; and 676 in low emissions and 446 in high emissions for the United States.
} 
Table A-17).

\subsection{Quasi-behavioral Measures of Social Norms}

To explore the role of norms in explaining support for international climate cooperation, we use quasi-behavioral measures of reciprocity and altruism.

\section{Reciprocity}

We measure reciprocity using the strategy method within the context of a two-player linear public good game (Fischbacher, Gächter and Fehr 2001; Selten 1967). Specifically, respondents were told that all individuals completing the survey had a chance to win one of two Amazon gift cards and that the amount of the gift card would depend on their decision about whether to give some amount of the gift card to another winner and the analogous decision made by that winning respondent. Any amount given to another respondent would be subtracted from the individual's winnings and doubled before it was distributed to the other winner. ${ }^{10}$ The strategy method asks individuals how much they would like to give the other winner if they knew that respondent's gift to them. Individuals are considered to be high reciprocity types if their gift amount is relatively sensitive to the gift of the other winner. Specifically, we estimated an auxiliary regression for each respondent in which we regressed her contribution on a variable that indicated the amount given by the other person $(0,25,50$, 75, and 100). We use the coefficients from these regressions as a measure of reciprocity. To account for potential measurement error and to stay consistent with the operationalization of our sector-based interests variable, we converted the reciprocity measure into a binary indicator, Reciprocity: High, that scores one for respondents that exhibited more reciprocal behavior than the median respondent and is zero otherwise.

\footnotetext{
${ }^{10}$ After completion of the field work two winners were drawn per country and the payoffs realized.
} 


\section{Altruism}

We also use a quasi-behavioral measure of individual's level of concern for the well-being of others. This measure of unconditional altruism is based on the following survey instrument: We informed respondents that we would raffle another $100 € / £ / \$$ among all respondents that completed the survey and that the winner could decide to donate parts of the voucher to a charity. We then asked respondents whether they would like to donate in case they won a voucher. If respondents indicated that they wanted to donate, we offered a long list of charities from which individuals could choose and we asked them the amount they would like to give. We coded the binary variable Altruism: High equal to one if respondents donated a nonzero amount (which also was the median donation) and zero otherwise. It is worth noting some minor distributional differences between, on the one hand, Germany and France and, on the other hand, the US and the UK, on the altruism variable. However, generally, both norm measures are similarly distributed across the four countries. Moreover, and in line with the conceptual difference between reciprocity and altruism, we find that the two measures are at most very weakly correlated (the correlation is 0.05 ).

\subsection{Predictors of Support for Climate Cooperation}

We first explore the socio-demographic dividing lines in support for global climate policy by regressing the variable Support: Global Climate Cooperation on measures of sociodemographic characteristics. Model 1 in Table 1 shows the baseline results, where we include fixed effects for the four countries and calculate robust standard errors. ${ }^{11}$ We find that individuals with higher levels of education are significantly more in favor of international climate cooperation as are individuals in the highest income quartile. We do not find significant differences by gender or age.

We address each part of our theoretical argument by separately focusing on the effect of

\footnotetext{
${ }^{11}$ The regressions employ sampling weights although there is no significant difference between the weighted and unweighted estimates.
} 
norms and interests on support for climate cooperation. Model 2 in Table 1 adds our binary measures of reciprocity and altruism. We find that both variables enter highly significant and have positive signs. On average, more reciprocal respondents are significantly more in favor of global climate policies as are individuals who are more altruistic. The coefficients are also sizable. Substantively, the effect of both variables is roughly a 10 percentage points increase in public support. Arguably, this evidence constitutes only an indirect test of the reciprocity argument, as we have no measure of beliefs about expected cooperation from others. However, the experimental results presented further below explicitly and exogenously vary the contribution other actors make (the participation dimension), which will allow for a more rigorous test of the theory.

Moving to test the second half of our argument, in Model 3 we evaluate the importance of sectoral-based interests by including the GHG Emissions: High variable. We find that respondents working in a more pollutive sector are significantly less supportive of global climate cooperation. The magnitude of this effect is closely comparable to the effects of social norms, in that working in an industry with a high environmental impact increases the support for climate cooperation by 8 percentage points.

To test whether social norms and industry-specific cost considerations independently explain support for climate cooperation, we estimate a fully specified model (Model 4) that includes all socio-demographic predictors as well as our measures of norms and interests. We find that the coefficients on our variables of interest remain significant and similar in terms of magnitudes. This suggests that norms and interests both add to our understanding of which individuals support climate cooperation and which oppose it.

To what extent do these results generalize to other facets of climate policy? We answer this question by re-estimating the fully specified model using our two additional measures of support for environmental policy. We first turn to the Importance of CO2 Reductions variable which captures the priority respondents attach to carbon abatements (Model 5 in Table 1). We again find that industry-based interests and social norms significantly correlate 
with the importance of $\mathrm{CO} 2$ reductions in ways consistent with our results on support for global climate cooperation. This suggests that sectoral interests and general beliefs about what constitutes socially appropriate behavior in the context of public goods problems helps explain why some individuals attach higher salience to addressing the sources of global warming than others.

Finally, we enrich these findings by exploring whether norms and industry-based interests also help explain variation in individuals' willingness to pay for environmental protection. The results from Model 6 in Table 1 suggest that again altruists are significantly more willing to pay for the environment while individuals employed in high-emission sectors are significantly less willing. Interestingly, the results change for the reciprocity measure. For the willingness to pay variable, we estimate that conditional cooperators, i.e., those with higher levels of reciprocity, are less willing to contribute than those with low levels of reciprocity. This switch of sign appears consistent with the theory because the willingness to pay emphasizes costs without a reference to the efforts of other countries and therefore, conditional cooperators should actually be less willing to back costly mitigation efforts under those circumstances.

While the evidence so far supports the view that both, interests and norms add to our understanding of the domestic political divisions between supporters of and opponents to climate policy, one may also argue that reciprocial considerations and altruistic concerns may be more powerful when the costs of climate policy are low, i.e., when it is relatively less costly to pursue ambitious, international climate policies. This reasoning predicts interaction effects between social norms and the costs of climate cooperation. For example, we would expect that the positive association between altruism and climate policy support is more pronounced among those working in low-emitter sectors than among individuals employed in sectors that produce large amounts of greenhouse gas emissions. To evaluate this argument we reestimated the main models and added multiplicative terms between the norms and interest variables. However, the empirical evidence lends weak to no support to this prediction. The 
coefficents on the interaction terms are mostly statistically indistinguishable from zero (see Table A-15 in the Appendix).

\section{Interests, Norms and Support for Climate Coopera- tion: Experimental Conjoint Evidence}

We have presented evidence suggesting that both norms and interests matter when trying to explain support for international climate policy. In the following, we complement our main findings with evidence from a randomized choice-based experiment in which individuals could choose their most preferred climate treaty. This analysis not only extends findings reported in Bechtel and Scheve (2013), but also validates our theoretical argument and largely confirms the results in the previous section using a different design setting.

\subsection{Conjoint Design}

Conjoint analysis has been developed in psychology and marketing and involves having respondents rank or rate two or more hypothetical choices that have multiple attributes with the objective of estimating the influence of each attribute on respondent choices or ratings (Hansen, Olsen and Bech 2015; Hainmueller, Hopkins and Yamamoto 2014; Bechtel and Scheve 2013; Gustafsson, Herrmann and Huber 2007; Green, Krieger and Wind 2001; Luce and Tukey 1964). We devise a fully-randomized (unrestricted) conjoint since none of the potential climate agreements described by the features (see below) seem internally inconsistent and feasible politically, although, in principle, even atypical combinations of features would not pose a threat to the internal validity of our causal estimates (Hainmueller, Hopkins and Yamamoto 2014). We show each respondent two international agreements in comparison and then ask to choose between them. This forced-choice design allows us to assess the influence of different features of climate change agreements on how individuals evaluate a given agreement relative to another. Each respondent was shown four such binary 
comparisons. For each agreement that a given respondent considered, we constructed the variable Agreement Support and coded it 1 if an individual chose that agreement and 0 if not.

Table 2 shows the dimensions and values used in the conjoint experiment. We focus on cost and participation features since these directly relate to our theoretical interest in the monetary costs of intensified climate policy and norms of conditional cooperation. Moreover, these features remain particularly contentious in the domestic politics of international environmental decision-making (Barrett and Stavins 2003) with important implications for the public debate on international climate policy in developed democracies (Nisbet and Myers 2007). The cost dimension distinguishes between the costs from policy implementation and potential sanctions imposed in case a country fails to meet its emission reduction obligations. We have chosen the values of the different features such that they correspond to the most plausible and widely discussed cost scenarios (Stern 2007; Cline 1992; Cline 2004). ${ }^{12}$ To make these cost quantities as informative as possible to our respondents, we computed prices in monthly costs to the average household in the country's currency. We computed monthly abatement costs to the average household for five different cost scenarios, ranging from $0.5 \%$ to $2.5 \%$ of a country's GDP in steps of 0.5 percentage points (OECD 2010; Ackerman and Bueno 2011). For sanctions, we distinguished between no sanction and a low, medium, and high sanction. For each country, the low, medium, and high sanction values correspond to $5 \%, 15 \%$, and $20 \%$ of the monthly household costs for the $2 \%$ of GDP scenario.

The participation dimension captures aspects that relate to issues of reciprocal or conditional cooperation. Specifically, we consider the number of countries that participate in a climate agreement and, as an alternative conceptualization of this dimension, the share of global emissions represented by these countries. The number of participating countries can vary from 20 to 80 to 160 out of 192 , and the percent of emissions accounted for by participating countries from $40 \%$ to $60 \%$ to $80 \%$ of current emissions. All these values were

\footnotetext{
${ }^{12}$ A modal estimate by climate scientists is that it will cost about 2 percent of industrialized countries' GDP to achieve a constant level of CO2 concentration at 550 particles per million (ppm).
} 
randomly assigned in the agreements that respondents had to consider. The order of the dimensions was randomly assigned for each respondent but remained consistent across the four binary comparisons (see Appendix for further information). We conducted a pilot study in which we tested the feasibility and relative strength of the attributes before fielding the main survey.

The experimental setup allows us to non-parametrically estimate the effects of costs and participation aspects on support for international climate cooperation by comparing levels of support across different values of the agreement dimensions (Hainmueller, Hopkins and Yamamoto 2014; Bechtel, Hainmueller and Margalit 2012). Our substantive focus is on estimating the average marginal component-specific effect, which corresponds to the average effect of a change in an agreement feature on the probability that a respondent chooses this agreement. Our analysis also explores how these treatment effects vary across different types of respondents in our sample - specifically respondents who face different costs or hold different norms. These conditional treatment effects are also non-parametrically identified in our fully randomized conjoint experiment as long as the respondent characteristics are not affected by the treatments, an assumption that appears plausible in our application.

Thanks to the randomization, we can estimate the effects of a climate agreement's costs and participation features on support for climate cooperation by computing differences in means. We obtain the difference-in-means estimators by regressing the variable Support Agreement on a set of dummy variables for each value of each dimension (with the exclusion of one value in each dimension as the baseline). ${ }^{13}$ The regression coefficient for each dummy variable indicates the average marginal component-specific effect of that value of the dimension relative to the omitted value of that dimension.

In contrast to Bechtel and Scheve (2013), we are not only interested in exploring how cost and participation attributes of climate treaties affect support for international climate cooperation but also in the extent to which sector-based interests as captured by our novel

\footnotetext{
${ }^{13}$ The regressions are weighted by sampling weights. We find no significant differences between the weighted and unweighted estimates.
} 
pollution measures moderate these effects. To this end we explore whether objective measures of the emission level of an individual's sector of employment conditions the sensitivites to agreement features in ways predicted by the theory.

\subsection{Climate Agreement Conjoint Results}

Figure 1 shows the estimated effects along with $95 \%$ confidence intervals based on three linear probability models in which we regress support for a climate on agreement features. The first model (diamonds) reports the average treatment effects estimated on the full sample. We find that individuals care about both the costs of implementing a climate change agreement and the inclusiveness of the treaty. Climate treaty support decreases significantly as the household costs arising from implementation increase: As the costs increase from $0.5 \%$ to $1 \%$ of GDP public support for a global climate agreement decreases by 10 percentage points. We also find that publics are sensitive to sanctions: On average, individuals prefer a small sanction over no sanction. However, agreements receive significantly less support when they include medium or high sanctions. For example, an agreement that imposes a high sanction on countries that failed to meet their obligations decreases public support by about 5 percentage points on average.

To what extent do these sensitivities mirror concerns about the sector-specific costs of intensified climate cooperation? To explore this question we first partition the data using our novel pollution measure and contrast respondents working in sectors with relatively low greenhouse gas emissions with those working in sectors with high emissions. Figure 1 reports the results.

We find that a medium sanction decreases support among respondents working in more pollutive industries significantly by about 5 percentage points. This is not the case for individuals employed in low-emission sectors who remain indifferent between a climate agreement that does not sanction excessive emissions and one that imposes a medium sanction. We also find a pronounced difference between the effects of a high sanction depending on the pollu- 
tiveness of respondents' sectors of employment. Among individuals working in low-emission industries a high sanction decreases support for a climate agreement by 3.7 percentage points on average. This effect doubles, however, when we consider those working in sectors with high levels of emissions. When estimating the heterogeneity of these treatment effects using interaction terms in a regression model, we find that the differences are statistically significant at the 5 percent level. This pattern suggests that sector-based variation in expectations about the costliness of intensified climate policy helps explain why some individuals are less supportive of climate agreements than others.

While we find a pronounced heterogeneity in the effects of sanctions, we do not find significant differences in the effects of household costs depending on the emissions produced by respondents' sectors of employment. One potential interpretation of this result is that the cost dimension assumes that mitigation takes place, i.e., these costs are certain. In contrast, sanctions will only apply in case of incomplete mitigation. Presumably, individuals form beliefs about the difficulty of climate mitigation and the probability of failing to meet emission targets based on their daily work experience. As a consequence, respondents in highemission industries may expect the risk of having to pay fines to be higher than individuals employed in sectors that produce only low amounts of greenhouse gases. Thus, individuals in high-pollution sectors will exhibit a greater degree of sensitivity to the inclusion of sanctions in a climate agreement because they factor in the probability of having to pay a fine which results in higher expected costs of joining a climate treaty. Since the household costs do not depend on this probability, the effects should be constant across individuals' sectors of employment, which is what we observe.

How do conditional cooperation features affect support for climate policy? Generally, we find that individuals prefer more encompassing agreements. An increase in the number of participating countries from 20 to 160 (out of 192) causes an increase in support for an agreement of 15 percentage points according to the full sample model. Similarly, although with smaller magnitudes, the proportion of current global emissions increases support for 
a climate agreement. These results suggest that both the costs and features related to conditional cooperation cause shifts in support for climate cooperation. Moreover, and consistent with the reciprocity argument, we find both that higher levels of cooperation (more participating countries/higher share of global emissions represented by participating countries) increase support for a climate treaty more strongly among individuals with high levels of reciprocity as measured by the behavior observed in our pre-treatment public goods experiment (see Figure A-6 in the Appendix).

Turning back to the role of industry-specific costs of abatement, we also find that these sectoral interests seem to matter when trying to understand the effect of conditional cooperation features: Individuals working in more pollutive sectors are significantly less sensitive to the participation dimension than respondents in less pollutive industries. For example, increasing the number of participating countries from 20 to 160 increases climate policy support by about 19 percentage points among respondents working in cleaner sectors. Among individuals employed in sectors with high greenhouse gas emissions, however, this effect is only 14 percentage points, a difference that is statistically significant and therefore evidences an interaction effect. The difference in the treatment effects of participation features is even more pronounced when we examine the effects of the share of emissions represented by participating countries: Respondents working in sectors that emit less greenhouse gases are more than twice as sensitive to conditional cooperation features than respondents in high-emission sectors.

\section{Willingness to Pay for Agreement Design Features}

We can further capitalize on the results from our randomized choice experiment to obtain estimates of individuals' willingness to pay for specific climate policy design features. To compute these quantities we have to re-estimate our main conjoint results using a continuous variable of the cost dimension. We regress the outcome variable agreement support on the 
continuous cost variable along with all agreement design indicator variables. The coefficient on this variable measures the cost elasticity of support for an agreement, i.e., the impact of a one $€, £, \$$ increase in the costs of a climate agreement on the probability of agreement support. Obviously, this parametrization relies on the assumption of a linear relationship between costs and support for a climate agreement. This assumption seems plausible given the results reported in Figure 1 which suggest that increases in the monetary costs of climate cooperation translate into lower support in a roughly linear fashion. We estimate the monetary value of each feature by multiplying its treatment effect with -1 and dividing the result by the coefficient on the cost variable. This conversion re-expresses the treatment effect such that it equals the monetary value of including a specific agreement design feature relative to the reference category. Since the cost sensitivities vary moderately by country, we compute the willingness to pay for agreement features separately for each country included in our analysis.

Table 3 reports the estimated willingness to pay for different agreement design components by country. The results suggest that individuals in France and Germany would pay $€ 17$ if a climate policy proposal included a small sanction instead of no sanction. Similarly, individuals would be willing to pay for more encompassing agreements: For example, our estimates suggest that publics in those two countries would pay $€ 31$ (France) and $€ 40$ (Germany) for increasing the number of participating countries from 20 to 80 . In the United Kingdom and the United States, the willingness to pay for including small sanctions for countries that have failed to meet their emission reduction targets is a bit lower $(\$ / £ 5)$ and publics in those countries also exhibit higher reluctance against the inclusion of medium and high sanctions as evidence by the more negative willingness-to-pay estimates. Overall, however, we find a relatively large degree of similarity in the willingness to pay for specific agreement design features. 


\section{Robustness}

Our results are robust to a large set of sensitivity tests. We first report the additional tests performed on the correlational data. We then turn to the robustness of the experimental conjoint findings.

\subsection{Robustness of Correlational Evidence}

We evaluate the robustness of the correlational results in several ways. We first explore the sensitivity of our findings to how we measure the pollutiveness of individuals' sectors of employment. We then reestimate our main model using an alternative measure of a sectors' level of greenhouse gas emissions that is based on the World Bank Development Indicators database. Model 1 in A-6 in the Appendix shows that this variable (GHG Emissions (WB): High) has a significantly negative coefficient, consistent with the prediction that those working in sectors that emit more greenhouse gases are systematically less in favor of climate cooperation. Model 2 reestimates our model using the difference between the level of greenhouse gas emissions and the level of non-CO2 gases as a sectoral-based interests indicator and also shows a significantly negative coefficient. Model 3 uses a measure of climate-relevant energy intensity in tonnes of oil equivalent (2011) weighted by the sectors' value added. Again, the coefficient is significantly negative which suggests that those working in more energy-intense sectors are more opposed to global climate policy efforts. In Model 4 we include an Employee-weighted GHG Emissions variable, which is the main GHG Emissions variable weighted by the number of employees in each of the 21 ISIC sectors. The results remain similar: Those working in more pollutive sectors are significantly less in favor of international climate cooperation.

We conducted an analogous set of robustness tests for our Importance of CO2 Reductions dependent variable, again using the same alternative measures of sector-based pollution costs. Table A-7 in the Appendix reports the estimates, which concord with our main findings. We 
repeat this exercise using our willingness to pay measure as the dependent variable. The results in Table A-8 are consistent with the finding that those working in more pollutive industries are less willing to pay for environmental protection. The strength of sectoralbased cleavages in public opinion over climate change policy stands in contrast to the public opinion literature on trade policy opinions which has largely failed to detect substantively significant cleavages by industry of employment (see e.g. Scheve and Slaughter (2001b)).

We also explore whether our estimates remain robust to including a variable that captures whether a respondent owns a car or not as an alternative measure of private interests. We report the results from these estimations in Table A-9 in the Appendix. Across all three dependent variables, our key findings are qualitatively the same with the estimate for car ownership negative and statistically significant in two out of the three specifications. Furthermore, we assess whether our results remain robust against the inclusion of individuals' ideological positions since a large literature has demonstrated that left-right ideology correlates with environmental policy preferences and ideology may also correlate with social norms. Table A-10 in the Appendix shows the results when we include a standard left-right measure that is based on individuals self-reported ideological position, and takes the value of one if the respondent identifies with the right and zero otherwise. We find that more rightist individuals are significantly more opposed to climate cooperation, less strongly believe that reducing emissions is important, and have a significantly lower willingness to pay for the environment. Most importantly, however, all our main findings remain intact even when accounting for individual differences in ideological convictions.

In our main estimations we have only considered employed individuals since the industrybased pollution measures are naturally missing for all respondents that are not in paid work. To further explore the robustness of our results we recode our main measure of industry-based pollutiveness such that it incorporates missing values as a separate category. Table A-11 in the Appendix reports the results. Although in Model 1 individuals not in paid employment are somewhat less in favor of climate cooperation than those working in cleaner sectors 
(the reference group), this correlation - which is only borderline significant - is no longer significant when we reestimate the model using the original 5-point scale. Our result that those working in sectors that emit more greenhouse gases are significantly less supportive of global climate policy remains robust to including individuals not in paid work.

A rival explanation for our findings could be that environmentalists self-select into working in sectors that emit less greenhouse gases. To address this issue we re-estimated our main model of support for climate cooperation including our "Importance of CO2 Reductions" measure of environmentalism as a control variable. This likely introduces endogeneity which would bias the results against our theoretical argument. ${ }^{14}$ It is nonetheless reassuring that, as the estimates reported in the last column in Table A-11 in the Appendix suggest, we still find that those working in high-emissions industries are less supportive of climate cooperation. We also assess the robustness of our results against adding an indicator variable that identifies individuals working in sectors with a large share of employees. As the results in Table A-14 indicate, our findings remain unchanged.

Finally, we investigate the within-country consistency of our findings by estimating our main model for each separate country. Table A-12 reports the results. These findings suggest some interesting heterogeneity across countries: Reciprocity has a strong positive effect on climate cooperation support among individuals in France, Germany and the United Kingdom, but the effect only borders significance in the United States. Contrastingly, altruists are not significantly more supportive of climate change agreements in France and Germany, while they are in the United Kingdom and the United States. With regards to our measure of economic interests, we find that the most notable differences exist in the United Kingdom and the United States. We believe these findings are consistent with a large literature on the interaction between the welfare state and support for trade openness. This literature argues that generous welfare states that redistribute the costs and benefits of integration with the world economy increase overall support for openness by mitigating domestic distributive

\footnotetext{
${ }^{14}$ Importance of CO2 Reductions is potentially a consequence of our key independent variables of interest and therefore a "bad" control that may introduce post-treatment bias.
} 
conflict and making the gains from globalization more widely shared (see e.g. Rodrik (1998) and Hays, Ehrlich and Peinhardt (2005)). We note, however, that the direction of the effects across all countries is consistent with our expectations, and overall validate our aggregate results. Table A-13 in the appendix offers further robustness tests employing ordered probit and tobit models to take into account various features of our dependent variables.

\subsection{Robustness of Conjoint-based Evidence}

We also perform sensitivity tests on experimental conjoint responses, despite the fact that the experimental research design allows us to dismiss the influence of confounders. We first explore the robustness of our findings by reestimating the results by alternative measures of industry-level pollution. Figure A-2 shows the results for the $G H G$ (WB) Emissions indicator. The findings remain very similar, and are perhaps even stronger than our main results suggest. Figure A-3 shows the results by CO2-only Emissions and Figure A-4 shows the treatment effects by Oil equivalent Energy Flows. Again, we find that economic interests have similar effects on support for climate cooperation when looking at the effects of participation features, e.g., the number of involved countries. Our results remain also unchanged when using the Employee-weighted GHG Emissions (Figure A-5) to split our sample.

One may also ask whether the conjoint instructions may have been understood better or read more carefully by respondents with higher levels of education. Alternatively, more educated individuals could generally pay more attention to the design of policy. However, as the results reported in Figure A-7 in the Appendix suggest, the evidence does not support this idea. Instead, we find that the design features have very similar effects on climate agreement support when comparing respondents with different levels of education.

Although our data does not lend itself to statistical analyses at the country level because it comprises only four countries, we did explore potential cross-country heterogeneity to check the consistency of the experimental data. Figure A-8 shows that the effects we estimate using the pooled data remain largely comparable when considering individual countries. We 
uncover some cross-country differences when looking at differences between individuals that work in more and less pollutive industries, which may reflect the different structures of the countries' economies as well as different types of welfare provision. Nonetheless, in all countries we find very similar sensitivities to cost and participation features of global climate agreements.

\section{Conclusion}

How can countries realize more effective global climate cooperation? The effectiveness of any climate agreement crucially depends on its domestic political popularity. If large parts of the national electorate remain antagonistic to a climate deal, its government will be reluctant to join it because it fears electoral backlash (Stokes 2015). Moreover, even if countries join an agreement, they are unlikely to meet the obligations necessary for mitigation efforts to be successful unless there is widespread public support for international efforts. However, governments can design climate agreements in ways such that their features generate high levels of domestic approval. Such optimal policy design necessitates scholarship that explores public support for climate agreements and domestic conflict over climate cooperation.

We argue that both individuals' sector-based interests and the presence of internalized social norms shape the popularity of international climate policy. In analyzing different types of survey data for France, Germany, the United Kingdom, and the United States we find empirical support for our argument. Both employment-related interests as well as social norms such as reciprocity and altruism significantly predict general support for climate cooperation, the importance individuals attach to realizing reductions in greenhouse gas emissions, and their willingness to pay for environmental protection more generally. Leveraging a randomized conjoint experiment we present additional evidence on the effects of cost- and participation-related features of climate agreements. More importantly, the effects of these features vary significantly between respondents working in sectors with high 
levels of greenhouse gas emissions and those whose sectors of employment are less pollutive in ways consistent with the theory.

In sum, our results not only offer a theoretically informative characterization of the dividing lines that underlie support for climate policies, but also contribute to a long-standing debate about the origins of preferences for policies that aim to provide public goods. By exploring the material and behavioral foundations of international environmental cooperation we offer useful information for policymakers interested in the conditions under which citizens are willing to approve climate cooperation. Our results suggest that both policies that compensate those who fear to lose economically from intensified climate change targets and forms of cooperation that resonate with widespread and largely time-invariant social norms (Carlsson, Johansson-Stenmann and Nam 2014) can contribute to reducing public opposition to costly global climate agreements, as exemplified by the German government's policy response to the recent protests of coal power producers against the introduction of a climate tax for highly polluting power plants. ${ }^{15}$ Rather than treating economic interests and social norms as rival explanations for differences in political views, our study suggests that combining both sets of factors may provide better insights into the sources of individual policy preferences across countries. Such a research agenda may also contribute to a better understanding of the conditions under which governments will reach cooperative solutions to global collective action problems in the face of domestic political constraints.

\footnotetext{
${ }^{15}$ See http: //www.reuters.com/article/2015/04/25/us-germany-coal-protests-idUSKBNONG0Q220150425 and http://www.euractiv.com/sections/energy/german-dirty-deal-brown-coal-criticised-318875.
} 


\section{References}

Ackerman, Frank and Ramón Bueno. 2011. Use of McKinsey Abatement Cost Curves for Climate Economics Modeling. Technical report Stockholm Environment Institute.

Alesina, Alberto and Paola Giuliano. 2011. Handbook of Social Economics. Elsevier B.V. chapter Preferences for Redistribution, pp. 93-131.

Allo and Loureiro. 2014. "The role of social norms on preferences towards climate change policies: A meta-analysis." Energy Policy 73:563-574.

Andreoni, James. 1990. "Impure Altruism and Donations To Public Goods: A Theory of Warm-Glow Giving." The Economic Journal 100(401):464-477.

Ansolabehere, Stephen and Brian F. Schaffner. 2013. "Does Survey Mode Still Matter? Findings From a 2010 Multi-Mode Comparison." Political Analysis forthcoming.

Ansolabehere, Stephen and Douglas Rivers. 2013. "Cooperative Survey Research." Annual Review of Political Science 16(1):1-23.

Babiker, Mustafa H. 2005. "Climate Change Policy, Market Structure, and Carbon Leakage." Journal of International Economics 65(2):421-445.

Barrett, Scott and Robert Stavins. 2003. "Increasing Participation and Compliance in International Climate Change Agreements." International Environmental Agreements: Politics, Law and Economics 3(4):349376 .

Bechtel, Michael M., Jens Hainmueller and Yotam Margalit. 2012. "Studying Public Opinion on Multidimensional Policies: The Case of the Eurozone Bailouts." Submitted Working Paper.

Bechtel, Michael M., Jens Hainmueller and Yotam Margalit. 2014. "Preferences for International Redistribution: The Divide Over the Eurozone Bailouts." American Journal of Political Science p. forthcoming.

Bechtel, Michael M. and Johannes Urpelainen. 2015. "All Policies Are Glocal: International Environmental Policymaking with Strategic Subnational Governments." British Journal of Political Science forthcoming.

Bechtel, Michael M. and Kenneth F. Scheve. 2013. "Mass Support for Climate Cooperation Depends on Institutional Design." Proceedings of the National Academy of Sciences 110(34):13763-13768.

Becker, Gary S. 1975. The Economic Approach to Human Behavior. Chicago: University of Chicago Press.

Becker, Gary S. 1983. "A Theory of Competition Among Pressure Groups for Political Influence." Quarterly Journal of Economics 98(3):371-400.

Böhmelt, Tobias. 2013. "Civil Society Lobbying and Countries' Climate Change Policies: A Matching Approach." Climate Policy 13(6):698-717.

Broz, J. Lawrence. 2005. "Congressional Politics of International Financial Rescues." American Journal of Political Science 49(3):479-496.

Camerer, Colin F. and Ernst Fehr. 2004. Measuring Social Norms and Preferences Using Experimental Games: A Guide for Social Scientists. In Foundations of Human Sociality: Economic Experiments and Ethnographic Evidence from Fifteen Small-scale Societies, ed. Joseph Henrich, Ernst Fehr and Herbert Gintis. Oxford University Press pp. 55-95.

Cao, Xun, Helen V. Milner, Aseem Prakash and Hugh Ward. 2014. "Research Frontiers in Comparative and International Environmental Politics: An Introduction." Comparative Political Studies 47(3):291-308.

Carlsson, Frederik, Mitesh Kataria, Alana Krupnick, Elina Lampi, Asa Löfgren, Pin Qin, Susie Chung and Thomas Sterner. 2012. "Paying for Mitigation: A Muptiple Country Study." Land Economics $88(2): 326-340$. 
Carlsson, Frerik, Olof Johansson-Stenmann and Pham Khanh Nam. 2014. "Social preferences are stable over long periods of time." 117 (Journal of Public Econmics):104-114.

Cline, William R. 1992. The Economcis of Global Warming. Washington DC: Peterson Institute for International Economics.

Cline, William R. 2004. Global Warming and Agriculture: Impact Estimates by Country. Washington, DC: Peterson Institute for International Economics.

Egan, Patrick and Megan Mullin. 2012. "Turning Personal Experience into Political Attitudes: The Effect of Local Weather on Americans' Perceptions about Global Warming." Journal of Politics 74(3):796-809.

Falk, Armin and Urs Fischbacher. 2006. "A Theory of Reciprocity." Games and Economic Behavior 54(2):293-315.

Fehr, Ernst and Simon Gächter. 2000. "Fairness and Retaliation: The Economics of Reciprocity." Journal of Economic Perspectives 14(3):159-181.

Fehr, Ernst and Urs Fischbacher. 2003. "The Nature of Human Altruism." Nature 425:785-791.

Fehr, Ernst and Urs Fischbacher. 2004. "Social Norms and Human Cooperation." TRENDS in Cognitive Sciences 8(4):185-190.

Fehr, Ernst and Urs Fischbacher. 2005. The Economics of Strong Reciprocity. In Moral Sentiments and Material Interests. The Foundations of Cooperation in Economic Life, ed. Herbert Gintis, Samuel Bowles, Robert Boyd and Ernst Fehr. MIT Press pp. 151-192.

Finnemore, Martha and Kathryn Sikkink. 2001. "Taking Stock: The Constructivist Research Programm in International Relations and Comparative Politics." Annual Review of Political Science 4:391-416.

Fischbacher, Urs and Simon Gächter. 2010. "Social Preferences, Beliefs, and the Dynamics of Free Riding in Public Goods Experiments." American Economic Review 100(1):541-556.

Fischbacher, Urs, Simon Gächter and Ernst Fehr. 2001. "Are People Conditionally Cooperative? Evidence from a Public Goods Experiment." Economics Letters 71(3):397-404.

Fredriksson, Per G., Eric Neumayer and Gergely Ujhelyi. 2007. "Kyoto Protocol Cooperation: Does Government Corruption Facilitate Environmental Lobbying?" Public Choice 133(1):231-251.

Gabel, Matthew J. 1998. "Economic Integration and Mass Politics: Market Liberalization and Public Attitudes in the European Union." American Journal of Political Science 42(3):936-953.

Gampfer, Robert, Thomas Bernauer and Aya Kachi. 2014. "Obtaining Public Support for North-South Climate Funding: Evidence from Conjoint Experiments in Donor Countries." Global Environmental Change 29:118-126.

Gilens, Martin. 2012. Why Americans Hate Welfare: Race, Media and the Politics of Anti-Poverty. University of Chicago Press.

Green, Paul E., Abba M. Krieger and Yoram Wind. 2001. "Thirty Years of Conjoint Analysis: Reflections and Prospects." Interfaces 31(3):56-73.

Gustafsson, Anders, Andreas Herrmann and Frank Huber. 2007. Conjoint Measurement. Methods and Applications. Berlin/Heidelberg/New York: Springer.

Hainmueller, Jens, Daniel Hopkins and Teppei Yamamoto. 2014. "Causal Inference in Conjoint Analysis: Understanding Multi-Dimensional Choices via Stated Preference Experiments." Political Analysis 22:130 .

Hainmueller, Jens and Michael J. Hiscox. 2006. "Learning to Love Globalization: Education and Individual Attitudes Toward International Trade." International Organization 60(2):469-498.

Hainmueller, Jens and Michael J. Hiscox. 2010. "Attitudes toward Highly Skilled and Low-skilled Immigration: Evidence from a Survey Experiment." American Political Science Review 104(1):61-84. 
Hansen, Kasper M., Asmus L. Olsen and Mickael Bech. 2015. "Cross-National Yardstick Comparisons: A Choice Experiment on a Forgotten Voter Heuristic." Political Behavior 37:767-789.

Hanson, Gordon H., Kenneth F. Scheve and Matthew J. Slaughter. 2007. "Public Finance and Individual Preferences over Globalization Strategies." Economics and Politics 19(1):1-33.

Hays, Jude C., Sean Ehrlich and Clint Peinhardt. 2005. "Government Spending and Public Support for Trade in the OECD: An Empirical Test of the Embedded Liberalism Thesis." International Organization 59(2):473-494.

Hoel, Michael. 1996. "Should a Carbon Tax be Differentiated across Sectors?" Journal of Public Economics $59(1): 17-32$.

Hopf, Ted. 1998. "The Promise of Constructivism in International Relations Theory." International Security 23(1):171-200.

Hovi, Jon, Detlef F. Sprinz and Arild Underdal. 2009. "Implementing Long-Term Climate Policy: Time Inconsistency, Domestic Politics, International Anarchy." Global Environmental Politics 9(3):20-39.

Keohane, Robert O. and David G. Victor. 2011. "The Regime Complex for Climate Change." Perspectives on Politics 9(1):7-23.

Kolstad, Charles D. 2014. Who Pays For Climate Regulation? Technical report Stanford Institute for Economic Policy Research.

Lü, Xiaobo, Kenneth F. Scheve and Matthew J. Slaughter. 2012. "Inequity Aversion and the International Distribution of Trade Protection." American Journal of Political Science 56(3):638-654.

Luce, R. Duncan and John W. Tukey. 1964. "Simultaneous Conjoint Measurement: A New Type of Fundamental Measurement." Journal of Mathematical Psychology 1:1-27.

Lupa, Noam and Jonas Pontusson. 2011. "The Structure of Inequality and the Politics of Redistribution." American Political Science Review 105(2):316-336.

Malhotra, Neil, Yotam Margalit and Cecilia Hyunjung Mo. 2013. "Economic Explanations for Opposition to Immigration: Distinguishing between Prevalence and Conditional Impact." American Journal of Political Science 57(2):391-419.

Mansfield, Edward D. and Diana C. Mutz. 2009. "Support for Free Trade: Self-Interest, Sociotropic Politics, and Out-Group Anxiety." International Organization 63(03):425-457.

March, James G. and Johan P. Olsen. 1998. "The Institutional Dynamics of International Political Orders." International Organization 52(4):943-969.

Mayda, Anna Maria. 2006. "Who Is Against Immigration? A Cross-Country Investigation of Attitudes Towards Immigrants." Review of Economics and Statistics 88(3):510-530.

Meltzer, Allan H. and Scott F. Richard. 1981. "A Rational Theory of the Size of Government." Journal of Political Economy 89(5):914-927.

Milinski, Manfred, Dirk Semmann, Hans-Juergen Krambeck and Jochem Marotzke. 2006. "Stabilizing the Earth's climate is not a losing game: Supporting evidence from public goods experiments." Proceedings of the National Academy of Sciences of the United States of America 103(11):3994-3998.

Naoi, Megumi and Ikuo Kume. 2011. "Explaining Mass Support for Agricultural Protectionism: Evidence from a Survey Experiment During the Global Recession." International Organization 65(4):771-795.

Nisbet, Matthew and Teresa Myers. 2007. "Twenty Years of Public Opinion About Global Warming." Public Opinion Quarterly 71(3):444-470.

OECD. 2010. Costs and Effectivenesss of the Copenhagen Pledges: Assessing the Global Greenhouse Gas Emissions Targets and Actions for 2020. Technical report OECD.

Olson, Mancur. 1965. The Logic of Collective Action: Public Goods and the Theory of Groups. Cambridge (Mass.): Harvard University Press. 
Ostrom, E. 2000. "Collective Action and the Evolution of Social Norms." Journal of Economic Perspectives 14:137-158.

Pandya, Sonal S. 2010. "Labor Markets and Demand for Foreign Direct Investment." International Organization 64(3):389-409.

Pittel, Karen and Dirk T. G. Rübbelke. 2008. "Climate Policy and Ancillary Benefits: A Survey and Integration into the Modelling of International Negotiations on Climate Change." Ecological Economics 68(1-2):210-220.

Rehm, Philipp, Jacob S. Hacker and Mark Schlesinger. 2012. "Insecure Alliances: Risk, Inequality, and Support for the Welfare State." American Political Science Review 106(2):386-406.

Rivers, Douglas. 2011. "Sample Matching: Representative Sampling from Internet Panels." YouGov White Paper.

Rodrik, Dani. 1998. "Why Do More Open Economies Have Bigger Governments?" Journal of Political Economy 106(5):997-1032.

Scheve, Kenneth F. and Matthew J. Slaughter. 2001a. "Labor Market Competition and Individual Preferences Over Immigration Policy." Review of Economics and Statistics 83(1):133-145.

Scheve, Kenneth F. and Matthew J. Slaughter. 2001b. "What Determines Individual Trade-Policy Preferences?" Journal of International Economics 54:267-292.

Selten, Reinhard. 1967. Die Strategiemethode zur Erforschung des eingeschränkt rationalen Verhaltens im Rahmen eines Oligopolexperiments. In Beiträge zur experimentellen Wirtschaftsforschung, ed. H. Sauermann. Tübingen: J.C.B. Mohr (Paul Siebeck) pp. 136-168.

Shayo, Moses. 2009. "A Model of Social Identity with an Application to Political Economy: Nation, Class and Redistribution." American Political Science Review 103(2):147-174.

Stern, Nicholas. 2007. The Stern Review on the Economics of Climate Change. Cambridge: Cambridge University Press.

Stokes, Leah C. 2015. "Electoral Backlash against Climate Policy: A Natural Experiment on Retrospective Voting and Local Resistance to Public Policy." American Journal of Political Science forthcoming.

Tingley, Dustin and Michael Tomz. 2014. "Conditional Cooperation and Climate Change." Comparative Political Studies 47(3):344-368.

Tvinnereim, Endre and Erick Lachapelle. 2014. "Is support for international climate action conditional on perceptions of reciprocity? Evidence from three population-based survey experiments in Canada, the US, and Norway.".

UNEP. 2012. The Emissions Gap Report 2012. A UNEP Synthesis Report. Technical report UNEP.

Urpelainen, Johannes. 2010. "Enforcing International Environmental Cooperation: Technological Standards Can Help." Review of International Organizations 5(4):475-496.

Victor, David G. 2006. "Effective International Cooperation on Climate Change: Numbers, Interests, and Institutions." Global Environmental Politics 6(3):90-103.

von Stein, Jana. 2008. "The International Law and Politics of Climate Change." Journal of Conflict Resolution 52(2):243-268.

Waltz, Kenneth N. 1979. Theory of International Politics. McGraw-Hill.

Ward, Hugh, Frank Grundig and Ethan R. Zorick. 2001. "Marching at the Pace of the Slowest: A Model of International Climate-Change Negotiations." Political Studies 49(3):438-461.

Weber, Max. 1968. Economy and Society. New York: Bedminster Press. 


\section{Tables}

\begin{tabular}{|c|c|c|c|c|c|c|}
\hline \multirow{2}{*}{$\begin{array}{r}\text { Dependent Variable } \\
\text { Model }\end{array}$} & \multicolumn{4}{|c|}{ Support for Climate Cooperation } & \multirow{2}{*}{$\begin{array}{c}\begin{array}{c}\text { Importance of CO2 } \\
\text { Reductions }\end{array} \\
(5)\end{array}$} & \multirow{2}{*}{$\begin{array}{c}\text { Environment: } \\
\text { Willingness to Pay }\end{array}$} \\
\hline & $\begin{array}{c}(1) \\
\text { Socio-demographics }\end{array}$ & $\begin{array}{c}(2) \\
\text { Norms }\end{array}$ & $\begin{array}{c}(3) \\
\text { Interest }\end{array}$ & $\begin{array}{l}\text { (4) } \\
\text { Full }\end{array}$ & & \\
\hline Female & $\begin{array}{r}-0.000 \\
(0.015)\end{array}$ & $\begin{array}{l}-0.004 \\
(0.015)\end{array}$ & $\begin{array}{l}-0.010 \\
(0.015)\end{array}$ & $\begin{array}{l}-0.013 \\
(0.015)\end{array}$ & $\begin{array}{c}0.581^{* * *} \\
(0.088)\end{array}$ & $\begin{array}{c}1.624^{* * *} \\
(0.617)\end{array}$ \\
\hline Age: $30-39$ & $\begin{array}{c}0.017 \\
(0.025)\end{array}$ & $\begin{array}{c}0.025 \\
(0.025)\end{array}$ & $\begin{array}{c}0.020 \\
(0.025)\end{array}$ & $\begin{array}{c}0.028 \\
(0.025)\end{array}$ & $\begin{array}{l}0.120 \\
(0.139)\end{array}$ & -0.160 \\
\hline Age: $40-49$ & $\begin{array}{l}-0.006 \\
(0.025)\end{array}$ & $\begin{array}{l}0.013 \\
(0.025)\end{array}$ & $\begin{array}{l}0.000 \\
(0.025)\end{array}$ & $\begin{array}{l}0.019 \\
(0.025)\end{array}$ & $\begin{array}{l}-0.135 \\
(0.145)\end{array}$ & $\begin{array}{l}-0.731 \\
(1.020)\end{array}$ \\
\hline Age: $50-59$ & $\begin{array}{l}0.016 \\
(0.025)\end{array}$ & $\begin{array}{l}0.040^{*} \\
(0.024)\end{array}$ & $\begin{array}{l}0.019 \\
(0.025)\end{array}$ & $\begin{array}{l}0.043^{*} \\
(0.024)\end{array}$ & $\begin{array}{l}0.036 \\
(0.145)\end{array}$ & $\begin{array}{l}-0.772 \\
(1.000)\end{array}$ \\
\hline Age: $60+$ & $\begin{array}{c}0.008 \\
(0.031)\end{array}$ & $\begin{array}{c}0.029 \\
(0.031)\end{array}$ & $\begin{array}{c}0.011 \\
(0.031)\end{array}$ & $\begin{array}{c}0.031 \\
(0.031)\end{array}$ & $\begin{array}{c}0.019 \\
(0.199)\end{array}$ & $\begin{array}{l}-1.438 \\
(1.264)\end{array}$ \\
\hline Income: Lower Middle & $\begin{array}{c}0.038 \\
(0.031)\end{array}$ & $\begin{array}{c}0.032 \\
(0.030)\end{array}$ & $\begin{array}{c}0.041 \\
(0.031)\end{array}$ & $\begin{array}{c}0.035 \\
(0.030)\end{array}$ & $\begin{array}{l}0.319^{*} \\
(0.174)\end{array}$ & $\begin{array}{c}0.397 \\
(1.268)\end{array}$ \\
\hline Income: Middle & $\begin{array}{l}0.050^{*} \\
(0.029)\end{array}$ & $\begin{array}{c}0.043 \\
(0.029)\end{array}$ & $\begin{array}{l}0.049^{*} \\
(0.029)\end{array}$ & $\begin{array}{c}0.042 \\
(0.029)\end{array}$ & $\begin{array}{l}0.310^{*} \\
(0.169)\end{array}$ & $\begin{array}{l}-0.302 \\
(1.191)\end{array}$ \\
\hline Income: High & $\begin{array}{c}0.066^{* *} \\
(0.028)\end{array}$ & $\begin{array}{c}0.056^{* *} \\
(0.028)\end{array}$ & $\begin{array}{c}0.066^{* *} \\
(0.028)\end{array}$ & $\begin{array}{c}0.057^{* *} \\
(0.028)\end{array}$ & $\begin{array}{c}0.033 \\
(0.166)\end{array}$ & $\begin{array}{l}-0.668 \\
(1.156)\end{array}$ \\
\hline Education: High & $\begin{array}{c}0.141^{* * *} \\
(0.016)\end{array}$ & $\begin{array}{c}0.130^{* * *} \\
(0.016)\end{array}$ & $\begin{array}{c}0.131^{* * * *} \\
(0.016)\end{array}$ & $\begin{array}{c}0.121^{* * *} \\
(0.016)\end{array}$ & $\begin{array}{c}0.319^{* * *} \\
(0.098)\end{array}$ & $\begin{array}{l}-0.111 \\
(0.684)\end{array}$ \\
\hline Reciprocity: High & & $\begin{array}{c}0.111^{* * *} \\
(0.015)\end{array}$ & & $\begin{array}{c}0.109^{* * *} \\
(0.015)\end{array}$ & $\begin{array}{c}0.543^{* * *} \\
(0.091)\end{array}$ & $\begin{array}{c}-2.445^{* * *} \\
(0.647)\end{array}$ \\
\hline Altruism: High & & $\begin{array}{c}0.095^{* * *} \\
(0.017)\end{array}$ & & $\begin{array}{c}0.094^{* * *} \\
(0.017)\end{array}$ & $\begin{array}{c}0.515^{* * *} \\
(0.102)\end{array}$ & $\begin{array}{c}3.560^{* * *} \\
(0.724)\end{array}$ \\
\hline GHG Emissions: High & & & $\begin{array}{c}-0.073^{* * *} \\
(0.015)\end{array}$ & $\begin{array}{c}-0.068^{* * *} \\
(0.015)\end{array}$ & $\begin{array}{c}-0.394^{* * *} \\
(0.092)\end{array}$ & $\begin{array}{c}-2.271^{* * *} \\
(0.641)\end{array}$ \\
\hline Germany & $\begin{array}{c}0.044^{* *} \\
(0.021)\end{array}$ & $\begin{array}{c}0.055^{* *} \\
(0.021)\end{array}$ & $\begin{array}{l}0.037^{*} \\
(0.021)\end{array}$ & $\begin{array}{c}0.048^{* *} \\
(0.021)\end{array}$ & $\begin{array}{l}-0.042 \\
(0.116)\end{array}$ & $\begin{array}{c}-0.683 \\
(0.992)\end{array}$ \\
\hline United Kingdom & $\begin{array}{c}-0.072^{* * *} \\
(0.021)\end{array}$ & $\begin{array}{c}-0.078 * * * \\
(0.021)\end{array}$ & $\begin{array}{c}-0.086 * * * \\
(0.021)\end{array}$ & $\begin{array}{c}-0.091^{* * *} \\
(0.021)\end{array}$ & $\begin{array}{c}-0.874^{* * *} \\
(0.111)\end{array}$ & $\begin{array}{c}-5.252^{* * * *} \\
(0.920)\end{array}$ \\
\hline United States & $\begin{array}{c}-0.237^{* * *} \\
(0.022)\end{array}$ & $\begin{array}{c}-0.244^{* * *} \\
(0.022)\end{array}$ & $\begin{array}{c}-0.247^{* * *} \\
(0.022)\end{array}$ & $\begin{array}{c}-0.253^{* * *} \\
(0.022)\end{array}$ & $\begin{array}{c}-1.590^{* * *} \\
(0.134)\end{array}$ & $\begin{array}{c}-3.025^{* * *} \\
(0.993)\end{array}$ \\
\hline Constant & $\begin{array}{c}0.581^{* * *} \\
(0.035)\end{array}$ & $\begin{array}{c}0.499^{* * *} \\
(0.035)\end{array}$ & $\begin{array}{c}0.628^{* * *} \\
(0.036)\end{array}$ & $\begin{array}{c}0.544^{* * *} \\
(0.037)\end{array}$ & $\begin{array}{c}6.379^{* * *} \\
(0.216)\end{array}$ & $\begin{array}{c}21.519^{* * *} \\
(1.613)\end{array}$ \\
\hline Observations & 4,008 & 4,008 & 4,008 & 4,008 & 4,009 & 4,009 \\
\hline R-squared & 0.069 & 0.090 & 0.074 & 0.095 & 0.085 & 0.023 \\
\hline
\end{tabular}

Table 1: Support for Climate Cooperation: Norms and Interests. This table reports OLS regression coefficients and robust standard errors (in parentheses). ${ }^{* * *} p<.01,{ }^{* *} p<.05$, ${ }^{*} p<.10$. Reference groups are: Sex: Male, Age: 18-29, Income: Low, Education: Low, Reciprocity: Low, Altruism: Low, GHG Emissions: Low, Country: France. The sample is employed respondents in the pooled data for France, Germany, the United Kingdom, and the United States. 


\begin{tabular}{ll} 
Dimension & Values \\
\hline \hline Costs & \\
\hline Costs to Average Household & $€ 28, € 39, £ 15, \$ 53$ per month \\
& $€ 56, € 77, £ 30, \$ 107$ per month \\
& $€ 84, € 116, £ 45, \$ 160$ per month \\
& $€ 113, € 154, £ 60, \$ 213$ per month \\
& $€ 141, € 193, £ 75, \$ 267$ per month \\
\hline Sanctions to Average Household & No sanction \\
& $€ 6, € 8, £ 3, \$ 11$ per month \\
& $€ 17, € 23, £ 9, \$ 32$ per month \\
& $€ 23, € 31, £ 12, \$ 43$ per month \\
\hline Participation & \\
\hline Number of Participating Countries & 20 out of 192 \\
& 80 out of 192 \\
& 160 out of 192 \\
\hline Emissions Represented & $40 \%$ of current emissions \\
& $60 \%$ of current emissions \\
& $80 \%$ of current emissions \\
\hline Other & \\
\hline Monitoring & Own government \\
& Independent commission \\
& United Nations \\
& Greenpeace \\
\hline Distribution of Costs & Only rich countries pay \\
& Proportional to current emissions \\
& Rich countries pay more than poor countries \\
\hline & \\
\hline & \\
& \\
& \\
& \\
& \\
& \\
&
\end{tabular}

Table 2: Policy Dimensions and Values for the Global Climate Agreement Experiment. The table shows the policy dimensions and corresponding values used in the conjoint experiment. For costs and sanctions, the values are given in order for France, Germany, the United Kingdom, and the United States. 


\begin{tabular}{|c|c|c|c|c|c|}
\hline Design Dimension & Feature & $\begin{array}{l}\text { France } \\
€\end{array}$ & $\begin{array}{l}\text { Germany } \\
€\end{array}$ & $\begin{array}{l}U K \\
£ \\
\end{array}$ & $\begin{array}{l}U S \\
\$\end{array}$ \\
\hline \multicolumn{6}{|l|}{ Costs } \\
\hline \multirow[t]{4}{*}{ Sanctions to Average Household } & No sanction & & & & \\
\hline & $€ 6, € 8, £ 3, \$ 11$ per month & 17 & 17 & 5 & 5 \\
\hline & $€ 17, € 23, £ 9, \$ 32$ per month & 3 & 4 & -18 & -12 \\
\hline & $€ 23, € 31, £ 12, \$ 43$ per month & -11 & -9 & -26 & -30 \\
\hline \multicolumn{6}{|l|}{ Participation } \\
\hline \multirow[t]{3}{*}{ Number of Participating Countries } & 20 out of 192 & & & & \\
\hline & 80 out of 192 & 31 & 40 & 39 & 28 \\
\hline & 160 out of 192 & 51 & 65 & 69 & 50 \\
\hline \multirow[t]{3}{*}{ Emissions Represented } & $40 \%$ of current emissions & & & & \\
\hline & $60 \%$ of current emissions & 10 & 9 & 11 & 5 \\
\hline & $80 \%$ of current emissions & 22 & 20 & 16 & 11 \\
\hline
\end{tabular}

Table 3: Willingness To Pay Estimates. The table shows estimates of how much individuals would be willing to pay for a specific agreement design feature based on the conjoint experiment results (see text for details). Rows without values are reference categories. 


\section{Figures}

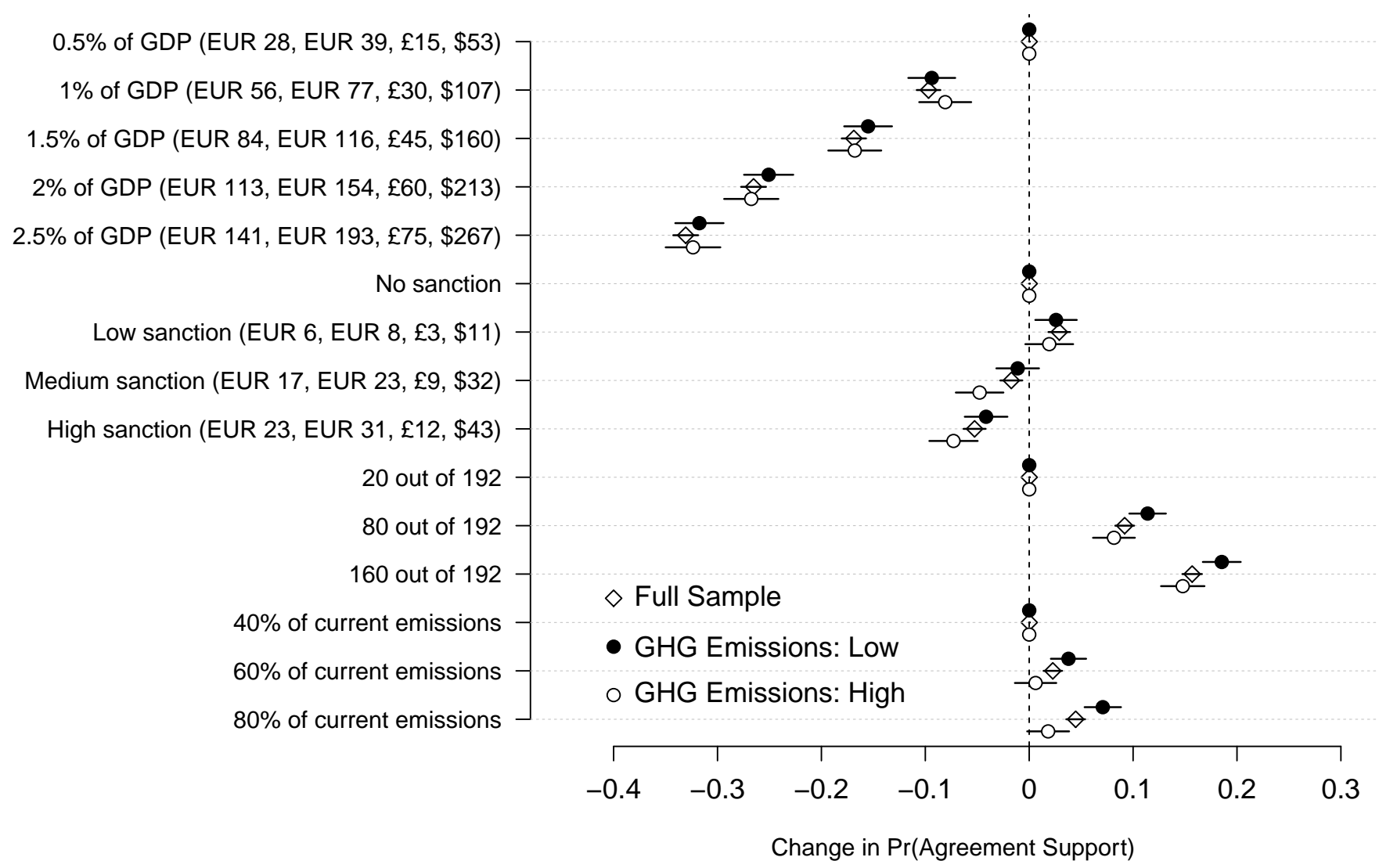

Figure 1: The Causal Effect of Costs and Participation on Support for Climate Agreements by GHG (CO2 equivalent) Emissions in France, Germany, the United Kingdom, and the United States. This plot shows the estimates of the effect of randomly assigned agreement features on the probability of supporting an agreement for the full sample (points, $N=68,000$ agreements) and by CO2-equivalent GHG emissions of respondents' sector of employment ( $N=33,408$ agreements). Estimates are based on the regression of Agreement Support on dummy variables for values of the agreement dimensions, with SEs clustered by respondent. The bars indicate $95 \%$ confidence intervals computed from robust standard errors clustered by respondent. Points without bars indicate the reference category for a given agreement dimension. 


\title{
Online Appendix
}

\section{Interests, Norms, and Attitudes toward Global Public Goods: The Case of Climate Cooperation}

\author{
Michael M. Bechtel Federica Genovese Kenneth F. Scheve
}

\section{Appendix: Sample}

Respondents were interviewed in summer 2012. In each country, respondents were subsequently matched down to a sample of 2,000 (except for the US were the sample was 2,500) based on gender, age, and education. The matched set of respondents was then weighted to the marginal distributions of sociodemographics in the country's total population. Weights were applied to remove remaining imbalances after the matching procedure. Table A-1 shows the distributions of the sociodemographics in the population, the weighted sample, and the raw sample.

\section{France}

- Interview period: August-September 2012

- Sample size: 2,000

- Source of data on population socio-demographics: Based on 2009 French population census, available from the French Statistical Institute (INSEE)

- Weights range from 0.66 to 1.39 , with a mean of one and a standard deviation of 0.28 .

\section{Germany}

- Interview period: August 2012

- Sample size: 2,000

- Source of data on population socio-demographics: September-October 2011 Eurobarometer survey

- Weights range from 0.63 to 1.60 , with a mean of one and a standard deviation of 0.32 .

\section{United Kingdom}

- Interview period: August 2012

- Sample size: 2,000

- Source of data on population socio-demographics: August-September 2010 Eurobarometer survey

- Weights range from 0.74 to 1.44 , with a mean of one and a standard deviation of 0.29.

\section{United States}

- Interview period: June 2012

- Sample size: 2,500

- Source of data on population socio-demographics: 2007 American Community Survey, the 2008 Current Population survey and the 2007 Pew Religious Landscape Survey

- Weights range from 0.56 to 1.9 , with a mean of one and a standard deviation of 0.29. 


\begin{tabular}{lccc}
\hline \hline Group & Population & Weighted Sample & Raw Sample \\
\hline France & & & \\
\hline Age: 18-39 & 31.6 & 31.6 & 34.2 \\
Age: 40-54 & 28.5 & 26.1 & 29.8 \\
Age: 55+ & 39.9 & 42.4 & 36.0 \\
Gender: Male & 47.6 & 47.6 & 47.6 \\
Gender: Female & 52.4 & 52.4 & 52.4 \\
Education: CAP/BEP or less & 59.8 & 59.8 & 46.9 \\
Education: Bac to Bac+2 & 27.5 & 27.5 & 36.1 \\
Education: Bac +3 or more & 12.7 & 12.7 & 16.9 \\
\hline Germany & & & \\
\hline Age: 18-34 & 23.1 & 23.1 & 34.2 \\
Age: 35-54 & 36.6 & 36.6 & 29.8 \\
Age: 55+ & 40.3 & 40.3 & 36.0 \\
Gender: Male & 49.0 & 49.0 & 49.0 \\
Gender: Female & 51.0 & 51.0 & 51.0 \\
Education: 16 years or fewer & 43.4 & 43.2 & 30.3 \\
Education: 17-19 years & 33.0 & 32.8 & 44 \\
Education: 20 years or more & 23.6 & 24.1 & 25.7 \\
\hline United Kingdom & & & \\
\hline Age: 18-34 & 23.4 & 23.4 & 25.4 \\
Age: 35-54 & 33.7 & 33.7 & 44.6 \\
Age: 55+ & 42.9 & 43.0 & 30.0 \\
Gender: Male & 47.3 & 47.3 & 47.3 \\
Gender: Female & 52.7 & 52.7 & 52.7 \\
Education: 16 years or fewer & 55.3 & 53.5 & 50.4 \\
Education: 17-19 years & 21.2 & 23.0 & 24.7 \\
Education: 20 years or more & 23.5 & 23.5 & 25.0 \\
\hline United States & & & \\
\hline Age: 18-34 & 29.5 & 27.1 & 19.4 \\
Age: 35-54 & 38.5 & 34.0 & 32.4 \\
Age: 55+ & 32.1 & 39.0 & 48.1 \\
Gender: Male & 48.2 & 48.2 & 47.6 \\
Gender: Female & 51.8 & 51.8 & 52.4 \\
Education: HS or less & 45.0 & 44.9 & 39.7 \\
Education: Some College & 30.0 & 22.2 & 23.4 \\
Education: College Graduate & 16.3 & 24.1 & 27.5 \\
Education: Postgraduate & 8.8 & 8.7 & 9.5 \\
\hline \hline & & & \\
\hline
\end{tabular}

Table A-1: Distribution of Socio-demographics in the Survey Sample and the Population. The table shows the distributions of socio-demographics in the population, the weighted sample, and the raw sample. See text for data sources on the population socio-demographics. $\mathrm{N}=8,500$ 


\section{Appendix: Industry Measures}

Our industry cost indicators measure the environmental impact (i.e. 'footprint') of the respondents' sectors of employment. In order to construct them, we first collected information on the respondents' employment status. In our survey we asked all 8,500 individuals to choose one of the following employment situations: paid work; in education; unemployed actively looking for a job; unemployed not actively looking for a job; permanently sick or disabled; retired; in community service; in military service; and doing housework. Those that selected paid work were asked in which type of industry they currently worked. We listed 21 options that correspond to the 21 categories of the United Nations Statistics Division's International Standard Industrial Classification (ISIC) of All Economic Activities (Revision 4) ${ }^{16}$ plus an an alternative 'none of these' category, in which case they were asked to describe in words their employment. After the survey we qualitatively evaluated the descriptions generated by this alternative category, to assess whether each of these individuals could actually be assigned to one of the 21 UNSD sectors based on the verbal description. For example, an American respondent in category 22 noted ' $I$ work in a supermarket', so we reassigned her to the Retail sector, because Group 471 under the ISIC Retail section $(\mathrm{G})$ includes "sale in non-specialized stores, such as supermarkets or department stores." Similarly, a French respondent wrote 'securité privé,' and was reassigned to the Administrative and Support Service sector, because Group 801 under the ISIC Administrative Services section (N) includes "security-related services such as investigation and detective services and guard and patrol services." The total of employed respondents is 4179 (854 in France, 978 in Germany, 1177 in the UK, 1170 in the US). Of these, 4009 respondents identified themselves as workers of one of the 21 specific sectors (817 in France, 929 in Germany, 1141 in the UK, 1122 in the US). Out of 792 'none of these' answers, we were able to reassign 625 employed respondents to one of the 21 ISIC categories. The ISIC categories upon which we constructed our pollution measures are listed in Table A-2.

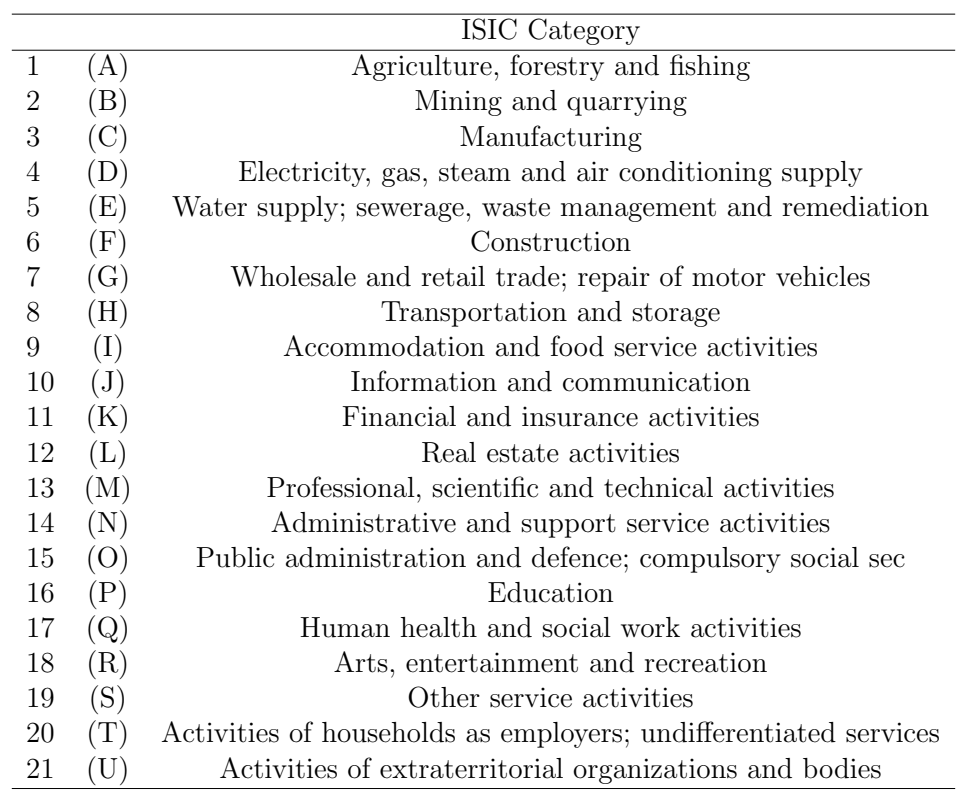

Table A-2: ISIC Categories

Our first and main industry indicator is the Greenhouse Gases (GHG) Emissions variable. This measures gross direct emissions in million tons of produced Co2 equivalent gases for the year 2011. The indicator comes from the OECD Environmental Statistics database, ${ }^{17}$ where GHG emissions follow the concept of

\footnotetext{
${ }^{16}$ Detailed structure and explanatory notes at: https://unstats.un.org/unsd/cr/registry/regcst . asp?Cl=27. Accessed on 6 August 2014.

${ }^{17}$ See database at $10.1787 /$ env-data-en.
} 
the International Panel on Climate Change (IPCC), the scientific intergovernmental body of the United Nations Framework Convention on Climate Change. According to the IPCC definition, GHG includes gaseous constituents of the atmosphere (both natural and anthropogenic) that absorb and emit radiations. The gases that are included in the definition are six: carbon dioxide $(\mathrm{CO} 2)$, nitrous oxide $(\mathrm{N} 2 \mathrm{O})$, methane (CH4), plus sulphur hexafluoride (SF6), hydrofluorocarbons (HFCs) and perfluorocarbons (PFCs). ${ }^{18}$

The IPCC (and thus the OECD) refers to emissions by six main industrial categories: Energy (1), Industrial Processes and Solvents (2), Agriculture (3), Waste, including water treatment and disposal (4), Land use Change and Forestry (5), and Others (6). The Energy sector is further broken down into the following 'subsectors': Electricity and Heat (1.A1); Manufacturing and Construction (1.A2); Transportation (1.A3); Fuel Combustion at the Source (Commercial and Residential) (1.A4) and Fugitive Emissions (1.B), including Extraction and Mining (1.A1C, 1.A5). We exclude Land-Use Change and Forestry, because this captures emission absorption and we are interested in emission production. Based on the rest of these main categories, we derived the 21 ISIC-concordant measures of GHG emissions by sector of employment according to conversion table A-3:

\begin{tabular}{|c|c|c|}
\hline IPCC (OECD) category & Transformation notes & ISIC category \\
\hline Energy (1.A1) & & ISIC 4 \\
\hline Manufacture \& Construction (1.A2) & $\begin{array}{c}\text { Manufacture \& Construction GHG } \\
\text { minus Manufacture \& Construction (GHG-CO2) }\end{array}$ & ISIC 3 \\
\hline Manufacture \& Construction (1.A2) & $\begin{array}{c}\text { Manufacture \& Construction (GHG-CO2) } \\
\text { plus Construction CO2 }\end{array}$ & ISIC 6 \\
\hline $\begin{array}{l}\text { Energy (1.A1C, 1.A5) \& } \\
\text { Fugitive Emissions (1.B) }\end{array}$ & & ISIC 2 \\
\hline Transport (1.A3) & & ISIC 8 \\
\hline Industrial Processes (2) & & ISIC 3 \\
\hline Agriculture (3) & & ISIC 1 \\
\hline Waste (4) & & ISIC 5 \\
\hline Fuel Combustion at Source (1.A4) & & ISIC 7 \\
\hline Others $(6)$ & $\begin{array}{c}\text { Assigned to 'other sectors' } \\
\text { and weighted by value added of each of these sectors }\end{array}$ & ISIC 9-21 \\
\hline
\end{tabular}

Table A-3: GHG Emissions Conversion Table: IPCC Categories and ISIC Categories.

The Manufacture \& Construction GHG emissions are disaggregated following the notion that construction is the main source of GHG beyond $\mathrm{CO} 2$ in the industry and production sector. Consequently, the emissions of Manufacture should be virtually equal to the CO2 of Manufacture. ${ }^{19}$ So we used the CO2-only emissions of manufacture and constructions from the OECD CO2 Emissions from Fuel Combustion Statistics ${ }^{20}$ and subtracted them from the Manufacture \& Construction GHG. The result is the non-CO2 emissions of the construction sector. We added this value to the construction sector CO2 and assigned the sum to ISIC 6 (Construction), while the CO2-only emissions for Manufacture were assigned to ISIC 3 (Manufacture). Both the Energy subcategories 1.A1C and 1.A5 are used to calculate the emissions in the Mining sector (ISIC 2), because together they make up the total emissions from fuel combusted in petroleum refineries, coal mining and oil and gas extraction. Fuel Combustion at Source (1.A4) instead measures combustion

\footnotetext{
${ }^{18}$ Ozone (O3) is technically a greenhouse gas, but it is not included in these calculations, since it does not directly affect the climate.

${ }^{19}$ There is general agreement on this assumption. For example, page 9 of the report 'Buildings and Climate Change,' the UNEP (2009) states that "the Construction Sector is responsible for the most significant non-CO2 GHG emissions such as halocarbons, CFCs, and HCFCs, due to their applications for cooling, refrigeration, and in the case of halocarbons, insulation material." See http://www. unep.org/sbci/pdfs/ sbci-bccsummary.pdf. Accessed on 6 August 2014.

${ }^{20}$ See database at $10.1787 /$ co2-data-en .
} 
from public and commercial services, referring to emissions from trade and retail. ${ }^{21}$ Finally, the Others (6) category includes all emissions that do not fall in the pre-set categories. Although it may overlap in some cases with residential emissions (from stationary sources), these are gases emitted mainly through 'Miscellaneous' combustion or small-scale installations from the rest of the economy. Unfortunately the 'others' value is not broken-down further, which makes it hard to match with the industries in the service sector from ISIC 9 (accommodation and food service) up to ISIC 21 (extraterritorial organizations). To calculate a proxy of the emissions for each employment sector in this range of service industries, we multiplied the total services emissions by each sector's proportion of the total service sectors value added. For example: for France 2011, the total value added of the tertiary (precisely ISIC 9 to ISIC 21) is 1136.05 billion Euros. The accommodation and food service activity sector (ISIC 9) had a value added of $44.37 \mathrm{~B}$ Euros. Also, the service sectors total GHG emissions sum up to $23.75 \mathrm{Mt}$. Then the emissions for the accommodation and food service sector of France is $(44.37 / 1136.05)^{*} 23.75=0.927$. Note that the value added data for France, Germany and the United Kingdom comes from the Eurostat, and is naturally broken down in the 21 ISIC sectors (the values are in Euros). By contrast, the value added of the US comes from the US Department of Commerce "GDP by industry" data, and it is in USD. ${ }^{22}$

Additional to the GHG Emissions indicators, we collected other measures for industry costs and pollution. The first alternative indicator is the World Bank GHG Emissions from the World Bank Development Indicators database. The World Bank compiles data of the International Energy Agency (IEA) in collaboration with the Carbon Dioxide Information Analysis Center. ${ }^{23}$ In the World Bank scheme, GHGs are measured for the following categories: (1) Agriculture; (2) Electricity and Heat; (3) Manufacture, Construction and Industrial Process; (4) Transportation; (5) Fuel Combustion at the Source (Extraction and Mining); (6) Residential; (7) Land Use Change and Forestry, (8) Other Sectors. These data is easier to use from an industrial sector point of view, but its most up to date series is from 2010, and the commercial and residential services are combined. ${ }^{24}$ We make the same transformations and weighting that we did for the IPCC GHG Emissions indicator, as per Table A- $4 .{ }^{25}$

\footnotetext{
${ }^{21}$ See discussion in Chapter 4 of the IPCC Guidelines for National Greenhouse Gas Inventories, 2006, http://www.ipcc-nggip.iges.or.jp/public/2006gl/pdf/1_Volume1/V1_4_Ch4_MethodChoice. pdf. Accessed on 6 August 2014.

${ }^{22}$ While in the paper we use the estimates based on this calculation of emissions in the service sectors, we alternatively followed a separate approach to find equal contributions in the service sectors. We divided the total emissions in 'others' by 13 and assigned this value to each of the ISIC from 9 to 21, without weighing by value added. The results are robust to both types of measures.

${ }^{23}$ See http://data.worldbank.org/about/world-development-indicators-data/environment.

${ }^{24}$ By including all activities of ISIC Divisions 41, 50-52, 55, 63-67, 70-75, 80, 85, 90-93 and 99 in the Residential (6) category, the GHG measure for trade and retail and residential emissions partially overlap.

${ }^{25}$ For a discussion of the World Bank GHG indicators data, see http://www.tsp-data-portal.org/ Breakdown-of-GHG-Emissions-by-SectortspQvAbout (Accessed on 6 August 2014) .See also full database at the Shift Project Data Portal, http://www.tsp-data-portal.org/.
} 


\begin{tabular}{lcc}
\hline World Bank categories & Transformation notes & ISIC categories \\
\hline Energy & & ISIC 4 \\
\hline $\begin{array}{l}\text { Manufacture, Construction } \\
\text { \& Indust'l Processes }\end{array}$ & $\begin{array}{c}\text { Manufacture, Construction \& Indust'l Processes GHG minus } \\
\text { Manufacture, Construction \& Indust'l Processes (GHG-CO2) }\end{array}$ & ISIC 3 \\
\hline $\begin{array}{l}\text { Manufacture, Construction } \\
\text { \& Indust'l Processes }\end{array}$ & $\begin{array}{c}\text { Manufacture, Construction \& Indust'l Processes (GHG-CO2) } \\
\text { plus Construction CO2 }\end{array}$ & ISIC 6 \\
\hline Energy \& Fugitive Emissions & & ISIC 2 \\
\hline Transport & & ISIC 8 \\
\hline Agriculture & ISIC 1 \\
\hline Waste & ASIC 5 \\
\hline Commercial services & Assigned to 'other sectors' and & ISIC 7 \\
\hline Residential and public services & ISIC 9-21 \\
\hline
\end{tabular}

Table A-4: GHG Emissions (WB) Conversion Table: IPCC Categories and ISIC Categories.

The two additional measures that we constructed for our analyses are the CO2 Emissions and the Oil equivalent Energy Flows variables. The $\mathrm{CO} 2$ Emissions are measured as gross directed emissions of million tons of produced carbon dioxide for the year 2011. This measure excludes other greenhouse gases. This means it will underestimate the climate impact of sectors that produce $\mathrm{N} 2 \mathrm{O}$ (e.g. agriculture), or CH4 (e.g. mining sectors). The Oil equivalent Energy Flows instead corresponds to the annual net flow (supply, trade and consumption) of coal, oil, energy output, gas, electricity, heat, combustible renewables and waste, expressed in tonnes of oil equivalent (toe) for the year 2011. We collect the CO2-only values from the 'Detailed CO2 Estimates' database based on the IEAs CO2 Emissions from Fuel Combustion Statistics and hosted by the OECD. ${ }^{26}$ This data follows the IPCC emission reporting guidelines and is broken down at lower sectoral levels. By contrast, the Energy Flows indicator comes from the IEA 'Extended World Energy Balances' database hosted by the OECD. ${ }^{27}$

For both types of indicators, we match the industry flows to the ISIC categories as per conversion table A-5. We rely on the 26 industries in the Detailed CO2 and Extended World Energy Balances databases, and aggregate them if necessary. For example, the volumes of 'agriculture and forestry' and 'fishing' are summed and together form the CO2 volume of the ISIC 1 category. Note however that the 'Commercial and public services' category in the IEA database is aggregated. We split into Commercial (ISIC 7) and Public Services (ISIC 9-21) following the Industrial Efficiency Policy Database (IEPD) figures, collected by the Institute for Industrial Productivity of the United Nations Industrial Development Organization (UNIDO). The IEPD figures are identical to the IEA figures for all industrial sectors, but further differentiate trade emissions/energy production and other services. ${ }^{28}$ We then subtracted from the IEA aggregate figures the two respective 'commercial' and 'other services' figures, to find the values for ISIC 7 and ISIC 9-21, respectively. We finally weighted the ISIC 9 through $21 \mathrm{CO} 2$ values like we did for GHG Emissions, using the value added of each sector.

\footnotetext{
${ }^{26}$ See the database at $10.1787 /$ co2-data-en. Note also that we prefer this data over the 'Per capita Co2 Emissions by Sector' and any other IEA dataset in the CO2 Emissions from Fuel Combustion Statistics because the latter are aggregated at the higher levels to the IPCC sectors, and these are not congruent with the 21 ISIC sectors. The Detailed CO2 estimates dataset helps us assembling CO2 of the 21 specific ISIC categories.

${ }^{27}$ See the database at 10.1787 /enestats-data-en.

${ }^{28}$ See database at http://iepd.iipnetwork.org/ and description at http://www.unido.org/en/ resources/statistics/statistical-databases.html.
} 


\begin{tabular}{lcc}
\hline IEA code & Transformation notes & ISIC code \\
\hline Agriculture and forestry & & ISIC 1 \\
Fishing & & ISIC 1 \\
Mining and quarrying & ISIC 2 \\
Chemical manufacturing & ISIC 3 \\
Food and tobacco manufacturing & ISIC 3 \\
Iron and steel manufacturing & ISIC 3 \\
Machinery manufacturing & ISIC 3 \\
Non energy use industry & ISIC 3 \\
Non ferrous metals manufacturing & & ISIC 3 \\
Non metallic minerals manufacturing & & ISIC 3 \\
Non specified industry & & ISIC 3 \\
Paper and pulp manufacturing & & ISIC 3 \\
Textile manufacturing & ISIC 3 \\
Transport equipment manufacturing & & ISIC 3 \\
Wood production & & ISIC 3 \\
Heat and electricity production & & ISIC 4 \\
Heat and electricity autoproducers & & ISIC 4 \\
Waste and water disposal & ISIC 5 \\
Construction & & ISIC 6 \\
Commercial and Public Services & Commercial and Public Services & ISIC 7 \\
& minus IEPD Other Services & \\
Domestic aviation & & ISIC 8 \\
Domestic navigation & & ISIC 8 \\
Pipeline transport & ISIC 8 \\
Rail transport & ISIC 8 \\
Road transport & ISIC 8 \\
Commercial and Public Services & Commercial and Public Services & ISIC $9-21$ \\
& minus IEPD Commercial \\
\hline
\end{tabular}

Table A-5: Conversion Table for CO2 Emissions and Oil Equivalent Energy Flows: IEA Categories and ISIC Categories.

Fourthly, we generated a further industry measure that we call the Employee-weighted GHG Emissions. Here we standardize the GHG Emissions variable by the total of employees in each sector. The employees data (in millions) for France, Germany and UK is broken down by 21 sectors and comes from the Eurostat's National Accounts. The employees data for the US comes from the US Department of Commerce 'GDP by industry' data, which breaks down employees across Bureau of Labor Statistics sub sectors that we aggregate at the 21 ISIC sectors. ${ }^{29}$ Evidently we have specific numbers of employees for the different tertiary industries (ISIC 9 to 21), however we do not know the specific figures of emissions of each service sector. Therefore, we follow the approach for the original non-standardized data, and divided the total of employees in industries ISIC 9 to 21 by 13 and assigned this value to each of the ISIC in this range.

${ }^{29}$ See US data at http://www. bea.gov/industry/gdpbyind_data.htm. 


\section{Appendix: Correlational Results}

\begin{tabular}{|c|c|c|c|c|}
\hline Dependent Variable & Supl & ort for Clin & late Cooper & ation \\
\hline Model & $(1)$ & $(2)$ & $(3)$ & $(4)$ \\
\hline Female & -0.013 & -0.007 & -0.007 & -0.013 \\
\hline & $(0.015)$ & $(0.015)$ & $(0.015)$ & $(0.015)$ \\
\hline Age: $30-39$ & 0.028 & 0.027 & 0.027 & 0.028 \\
\hline & $(0.025)$ & $(0.025)$ & $(0.025)$ & $(0.025)$ \\
\hline Age: $40-49$ & 0.018 & 0.017 & 0.016 & 0.018 \\
\hline & $(0.025)$ & $(0.025)$ & $(0.025)$ & $(0.025)$ \\
\hline Age: $50-59$ & $0.042^{*}$ & $0.042^{*}$ & $0.042^{*}$ & $0.042^{*}$ \\
\hline & $(0.024)$ & $(0.024)$ & $(0.024)$ & $(0.024)$ \\
\hline Age: $60+$ & 0.030 & 0.031 & 0.030 & 0.030 \\
\hline & $(0.031)$ & $(0.031)$ & $(0.031)$ & $(0.031)$ \\
\hline Income: Lower Middle & 0.034 & 0.030 & 0.030 & 0.034 \\
\hline & $(0.030)$ & $(0.030)$ & $(0.030)$ & $(0.030)$ \\
\hline Income: Middle & 0.042 & 0.042 & 0.042 & 0.042 \\
\hline & $(0.029)$ & $(0.029)$ & $(0.029)$ & $(0.029)$ \\
\hline Income: High & $0.056^{* *}$ & $0.057^{* *}$ & $0.057^{* *}$ & $0.056^{* *}$ \\
\hline & $(0.028)$ & $(0.028)$ & $(0.028)$ & $(0.028)$ \\
\hline Education: High & $0.120^{* * *}$ & $0.129^{* * *}$ & $0.129^{* * *}$ & $0.120^{* * *}$ \\
\hline & $(0.016)$ & $(0.016)$ & $(0.016)$ & $(0.016)$ \\
\hline Reciprocity: High & $0.109^{* * *}$ & $0.110^{* * *}$ & $0.110^{* * *}$ & $0.109^{* * *}$ \\
\hline & $(0.015)$ & $(0.015)$ & $(0.015)$ & $(0.015)$ \\
\hline Altruism: High & $0.094^{* * *}$ & $0.093^{* * *}$ & $0.094^{* * *}$ & $0.094^{* * *}$ \\
\hline & $(0.017)$ & $(0.017)$ & $(0.017)$ & $(0.017)$ \\
\hline GHG Emissions (WB): High & $\begin{array}{c}-0.071^{* * *} \\
(0.015)\end{array}$ & & & \\
\hline CO2 Emissions: High & & $\begin{array}{c}-0.045^{* * *} \\
(0.015)\end{array}$ & & \\
\hline Oil eq Energy Flow: High & & & $\begin{array}{c}-0.043^{* * *} \\
(0.015)\end{array}$ & \\
\hline Employee-weighted GHG: High & & & & $\begin{array}{c}-0.071^{* * * *} \\
(0.015)\end{array}$ \\
\hline Germany & $\begin{array}{c}0.054^{* *} \\
(0.021)\end{array}$ & $\begin{array}{c}0.056^{* * *} \\
(0.021)\end{array}$ & $\begin{array}{c}0.056^{* * *} \\
(0.021)\end{array}$ & $\begin{array}{c}0.054^{* *} \\
(0.021)\end{array}$ \\
\hline United Kingdom & $\begin{array}{c}-0.086^{* * *} \\
(0.021)\end{array}$ & $\begin{array}{c}-0.080^{* * * *} \\
(0.021)\end{array}$ & $\begin{array}{c}-0.080^{* * *} \\
(0.021)\end{array}$ & $\begin{array}{c}-0.086^{* * * *} \\
(0.021)\end{array}$ \\
\hline United States & $-0.247^{* * *}$ & $-0.247^{* * *}$ & $-0.246^{* * *}$ & $-0.247^{* * *}$ \\
\hline & $(0.022)$ & $(0.022)$ & $(0.022)$ & $(0.022)$ \\
\hline Constant & $0.542^{* * *}$ & $0.526^{* * *}$ & $0.524^{* * *}$ & $0.542^{* * *}$ \\
\hline & $(0.037)$ & $(0.037)$ & $(0.037)$ & $(0.037)$ \\
\hline Observations & 4,008 & 4,008 & 4,008 & 4,008 \\
\hline R-squared & 0.095 & 0.092 & 0.092 & 0.095 \\
\hline
\end{tabular}

Table A-6: Support for Climate Cooperation: Norms and Interests (Alternative Measures of Pollution Cost). This table reports OLS regression coefficients and robust standard errors (in parentheses). ${ }^{* * *} p<.01,{ }^{* *} p<.05,{ }^{*} p<.10$. Reference groups are: Sex: Male, Age: 18-29, Income: Low, Education: Low, Reciprocity: Low, Altruism: Low, GHG (World Bank) Emissions: Low, CO2 Emissions: Low, Oil equivalent Energy Flow: Low, Employee-weighted GHG Emissions: Low, Country: France. The sample is employed respondents in the pooled data for France, Germany, the United Kingdom, and the United States. 


\begin{tabular}{|c|c|c|c|c|}
\hline Dependent Variable & \multicolumn{4}{|c|}{ Importance of CO2 Reductions } \\
\hline Model & $(1)$ & $(2)$ & $(3)$ & $(4)$ \\
\hline Female & $\begin{array}{c}0.582^{* * *} \\
(0.088)\end{array}$ & $\begin{array}{c}0.617^{* * *} \\
(0.088)\end{array}$ & $\begin{array}{c}0.619^{* * *} \\
(0.088)\end{array}$ & $\begin{array}{c}0.582^{* * *} \\
(0.088)\end{array}$ \\
\hline Age: $30-39$ & $\begin{array}{c}0.119 \\
(0.139)\end{array}$ & $\begin{array}{c}0.115 \\
(0.139)\end{array}$ & $\begin{array}{c}0.115 \\
(0.139)\end{array}$ & $\begin{array}{c}0.119 \\
(0.139)\end{array}$ \\
\hline Age: $40-49$ & $\begin{array}{l}-0.141 \\
(0.145)\end{array}$ & $\begin{array}{l}-0.146 \\
(0.145)\end{array}$ & $\begin{array}{l}-0.147 \\
(0.145)\end{array}$ & $\begin{array}{l}-0.141 \\
(0.145)\end{array}$ \\
\hline Age: $50-59$ & $\begin{array}{c}0.032 \\
(0.145)\end{array}$ & $\begin{array}{c}0.030 \\
(0.145)\end{array}$ & $\begin{array}{c}0.031 \\
(0.145)\end{array}$ & $\begin{array}{c}0.032 \\
(0.145)\end{array}$ \\
\hline Age: $60+$ & $\begin{array}{c}0.014 \\
(0.199)\end{array}$ & $\begin{array}{c}0.016 \\
(0.199)\end{array}$ & $\begin{array}{c}0.015 \\
(0.199)\end{array}$ & $\begin{array}{c}0.014 \\
(0.199)\end{array}$ \\
\hline Income: Lower Middle & $\begin{array}{l}0.317^{*} \\
(0.174)\end{array}$ & $\begin{array}{l}0.292^{*} \\
(0.174)\end{array}$ & $\begin{array}{l}0.293^{*} \\
(0.174)\end{array}$ & $\begin{array}{l}0.317^{*} \\
(0.174)\end{array}$ \\
\hline Income: Middle & $\begin{array}{l}0.307^{*} \\
(0.169)\end{array}$ & $\begin{array}{l}0.307^{*} \\
(0.169)\end{array}$ & $\begin{array}{l}0.309^{*} \\
(0.169)\end{array}$ & $\begin{array}{l}0.307^{*} \\
(0.169)\end{array}$ \\
\hline Income: High & $\begin{array}{c}0.027 \\
(0.166)\end{array}$ & $\begin{array}{c}0.038 \\
(0.166)\end{array}$ & $\begin{array}{c}0.038 \\
(0.166)\end{array}$ & $\begin{array}{c}0.027 \\
(0.166)\end{array}$ \\
\hline Education: High & $\begin{array}{c}0.318^{* * *} \\
(0.098)\end{array}$ & $\begin{array}{c}0.367^{* * *} * \\
(0.098)\end{array}$ & $\begin{array}{c}0.370^{* * *} \\
(0.098)\end{array}$ & $\begin{array}{c}0.318^{* * *} \\
(0.098)\end{array}$ \\
\hline Reciprocity: High & $\begin{array}{c}0.543^{* * *} \\
(0.091)\end{array}$ & $\begin{array}{c}0.553^{* * *} \\
(0.091)\end{array}$ & $\begin{array}{c}0.553^{* * *} \\
(0.091)\end{array}$ & $\begin{array}{c}0.543^{* * *} \\
(0.091)\end{array}$ \\
\hline Altruism: High & $\begin{array}{c}0.515^{* * *} \\
(0.102)\end{array}$ & $\begin{array}{c}0.511^{* * *} \\
(0.102)\end{array}$ & $\begin{array}{c}0.514^{* * *} \\
(0.102)\end{array}$ & $\begin{array}{c}0.515^{* * *} \\
(0.102)\end{array}$ \\
\hline GHG Emissions (WB): High & $\begin{array}{c}-0.392^{* * *} \\
(0.092)\end{array}$ & & & \\
\hline CO2 Emissions: High & & $\begin{array}{c}-0.262^{* * *} \\
(0.090)\end{array}$ & & \\
\hline Oil eq Energy Flow: High & & & $\begin{array}{c}-0.241^{* * *} \\
(0.090)\end{array}$ & \\
\hline Employee-weighted GHG: High & & & & $\begin{array}{c}-0.392^{* * *} \\
(0.092)\end{array}$ \\
\hline Germany & $\begin{array}{c}-0.008 \\
(0.116)\end{array}$ & $\begin{array}{c}0.002 \\
(0.115)\end{array}$ & $\begin{array}{c}0.001 \\
(0.115)\end{array}$ & $\begin{array}{c}-0.008 \\
(0.116)\end{array}$ \\
\hline United Kingdom & $\begin{array}{c}-0.841^{* * *} \\
(0.110)\end{array}$ & $\begin{array}{c}-0.811^{* * *} \\
(0.110)\end{array}$ & $\begin{array}{c}-0.810^{* * *} \\
(0.110)\end{array}$ & $\begin{array}{c}-0.841^{* * *} \\
(0.110)\end{array}$ \\
\hline United States & $\begin{array}{c}-1.556^{* * *} \\
(0.133)\end{array}$ & $\begin{array}{c}-1.555^{* * *} \\
(0.133)\end{array}$ & $\begin{array}{c}-1.547^{* * *} \\
(0.133)\end{array}$ & $\begin{array}{c}-1.556^{* * *} \\
(0.133)\end{array}$ \\
\hline Constant & $\begin{array}{c}6.352^{* * *} \\
(0.214)\end{array}$ & $\begin{array}{c}6.273^{* * *} \\
(0.214)\end{array}$ & $\begin{array}{c}6.257^{* * *} * \\
(0.214)\end{array}$ & $\begin{array}{c}6.352^{* * *} \\
(0.214)\end{array}$ \\
\hline Observations & 4,009 & 4,009 & 4,009 & 4,009 \\
\hline R-squared & 0.085 & 0.083 & 0.082 & 0.085 \\
\hline
\end{tabular}

Table A-7: Importance of CO2 Reductions: Norms and Interests (Alternative Measures of Pollution Cost). This table reports OLS regression coefficients and robust standard errors (in parentheses). ${ }^{* * *} p<.01,{ }^{* *} p<.05,{ }^{*} p<.10$. Reference groups are: Sex: Male, Age: 18-29, Income: Low, Education: Low, Reciprocity: Low, Altruism: Low, GHG (World Bank) Emissions: Low, CO2 Emissions: Low, Oil equivalent Energy Flow: Low, Employee-weighted GHG Emissions: Low, Country: France. The sample is employed respondents in the pooled data for France, Germany, the United Kingdom, and the United States. 


\begin{tabular}{|c|c|c|c|c|}
\hline Dependent Variable & \multicolumn{4}{|c|}{ Environment: Willingness to Pay } \\
\hline Model & $(1)$ & $(2)$ & $(3)$ & $(4)$ \\
\hline Female & $\begin{array}{c}1.648^{* * *} \\
(0.619)\end{array}$ & $\begin{array}{c}1.815^{* * *} \\
(0.613)\end{array}$ & $\begin{array}{c}1.825^{* * *} \\
(0.614)\end{array}$ & $\begin{array}{c}1.648^{* * *} \\
(0.619)\end{array}$ \\
\hline Age: $30-39$ & $\begin{array}{l}-0.173 \\
(1.031)\end{array}$ & $\begin{array}{l}-0.179 \\
(1.032)\end{array}$ & $\begin{array}{l}-0.176 \\
(1.032)\end{array}$ & $\begin{array}{l}-0.173 \\
(1.031)\end{array}$ \\
\hline Age: $40-49$ & $\begin{array}{c}-0.778 \\
(1.020)\end{array}$ & $\begin{array}{c}-0.772 \\
(1.021)\end{array}$ & $\begin{array}{l}-0.775 \\
(1.022)\end{array}$ & $\begin{array}{l}-0.778 \\
(1.020)\end{array}$ \\
\hline Age: $50-59$ & $\begin{array}{l}-0.800 \\
(1.001)\end{array}$ & $\begin{array}{l}-0.796 \\
(1.002)\end{array}$ & $\begin{array}{c}-0.782 \\
(1.002)\end{array}$ & $\begin{array}{l}-0.800 \\
(1.001)\end{array}$ \\
\hline Age: $60+$ & $\begin{array}{l}-1.472 \\
(1.264)\end{array}$ & $\begin{array}{c}-1.442 \\
(1.268)\end{array}$ & $\begin{array}{c}-1.444 \\
(1.268)\end{array}$ & $\begin{array}{l}-1.472 \\
(1.264)\end{array}$ \\
\hline Income: Lower Middle & $\begin{array}{c}0.382 \\
(1.267)\end{array}$ & $\begin{array}{c}0.227 \\
(1.267)\end{array}$ & $\begin{array}{c}0.227 \\
(1.267)\end{array}$ & $\begin{array}{c}0.382 \\
(1.267)\end{array}$ \\
\hline Income: Middle & $\begin{array}{l}-0.319 \\
(1.190)\end{array}$ & $\begin{array}{l}-0.327 \\
(1.190)\end{array}$ & $\begin{array}{l}-0.316 \\
(1.190)\end{array}$ & $\begin{array}{l}-0.319 \\
(1.190)\end{array}$ \\
\hline Income: High & $\begin{array}{l}-0.701 \\
(1.155)\end{array}$ & $\begin{array}{l}-0.630 \\
(1.156)\end{array}$ & $\begin{array}{l}-0.625 \\
(1.157)\end{array}$ & $\begin{array}{l}-0.701 \\
(1.155)\end{array}$ \\
\hline Education: High & $\begin{array}{c}-0.094 \\
(0.686)\end{array}$ & $\begin{array}{c}0.156 \\
(0.673)\end{array}$ & $\begin{array}{c}0.171 \\
(0.673)\end{array}$ & $\begin{array}{c}-0.094 \\
(0.686)\end{array}$ \\
\hline Reciprocity: High & $\begin{array}{c}-2.442^{* * *} \\
(0.647)\end{array}$ & $\begin{array}{c}-2.398^{* * *} \\
(0.647)\end{array}$ & $\begin{array}{c}-2.399^{* * *} \\
(0.647)\end{array}$ & $\begin{array}{c}-2.442^{* * *} \\
(0.647)\end{array}$ \\
\hline Altruism: High & $\begin{array}{c}3.564^{* * *} \\
(0.724)\end{array}$ & $\begin{array}{c}3.531^{* * *} \\
(0.723)\end{array}$ & $\begin{array}{c}3.551^{* * *} \\
(0.723)\end{array}$ & $\begin{array}{c}3.564^{* * *} \\
(0.724)\end{array}$ \\
\hline GHG Emissions (WB): High & $\begin{array}{c}-2.095^{* * *} \\
(0.640)\end{array}$ & & & \\
\hline CO2 Emissions: High & & $\begin{array}{c}-1.857^{* * *} \\
(0.628)\end{array}$ & & \\
\hline Oil eq Energy Flow: High & & & $\begin{array}{c}-1.780^{* * *} \\
(0.628)\end{array}$ & \\
\hline Employee-weighted GHG: High & & & & $\begin{array}{c}-2.095^{* * *} \\
(0.640)\end{array}$ \\
\hline Germany & $\begin{array}{c}-0.488 \\
(0.988)\end{array}$ & $\begin{array}{c}-0.419 \\
(0.986)\end{array}$ & $\begin{array}{c}-0.422 \\
(0.986)\end{array}$ & $\begin{array}{c}-0.488 \\
(0.988)\end{array}$ \\
\hline United Kingdom & $\begin{array}{c}-5.043^{* * *} \\
(0.912)\end{array}$ & $\begin{array}{c}-4.900^{* * *} \\
(0.908)\end{array}$ & $\begin{array}{c}-4.898^{* * *} \\
(0.909)\end{array}$ & $\begin{array}{c}-5.043^{* * *} \\
(0.912)\end{array}$ \\
\hline United States & $\begin{array}{c}-2.820^{* * *} \\
(0.987)\end{array}$ & $\begin{array}{c}-2.846^{* * *} \\
(0.990)\end{array}$ & $\begin{array}{c}-2.796^{* * *} \\
(0.989)\end{array}$ & $\begin{array}{c}-2.820^{* * *} \\
(0.987)\end{array}$ \\
\hline Constant & $\begin{array}{c}21.268^{* * *} \\
(1.601)\end{array}$ & $\begin{array}{c}21.114^{* * *} \\
(1.586)\end{array}$ & $\begin{array}{c}21.044^{* * *} \\
(1.583)\end{array}$ & $\begin{array}{c}21.268^{* * *} \\
(1.601)\end{array}$ \\
\hline Observations & 4,009 & 4,009 & 4,009 & 4,009 \\
\hline R-squared & 0.022 & 0.022 & 0.022 & 0.022 \\
\hline
\end{tabular}

Table A-8: Willingness to Pay for the Environment: Norms and Interests (Alternative Measures of Pollution Cost). This table reports OLS regression coefficients and robust standard errors (in parentheses). ${ }^{* * *} p<.01,{ }^{* *} p<.05,{ }^{*} p<.10$. Reference groups are: Sex: Male, Age: 18-29, Income: Low, Education: Low, Reciprocity: Low, Altruism: Low, GHG (World Bank) Emissions: Low, CO2 Emissions: Low, Oil equivalent Energy Flow: Low, Employeeweighted GHG Emissions: Low, Country: France. The sample is employed respondents in the pooled data for France, Germany, the United Kingdom, and the United States. 


\begin{tabular}{|c|c|c|c|}
\hline Dependent Variable & $\begin{array}{c}\text { Support for } \\
\text { Climate Cooperation }\end{array}$ & $\begin{array}{c}\text { Importance of } \mathrm{CO} 2 \\
\text { Reductions }\end{array}$ & $\begin{array}{c}\text { Environment: } \\
\text { Willingness to Pay }\end{array}$ \\
\hline Model & $(1)$ & $(2)$ & $(3)$ \\
\hline \multirow[t]{2}{*}{ Female } & -0.013 & $0.585^{* * *}$ & $1.634^{* * *}$ \\
\hline & $(0.015)$ & $(0.088)$ & $(0.617)$ \\
\hline \multirow[t]{2}{*}{ Age: 30-39 } & 0.03 & 0.146 & -0.094 \\
\hline & $(0.025)$ & $(0.138)$ & $(1.035)$ \\
\hline \multirow[t]{2}{*}{ Age: $40-49$} & 0.023 & -0.085 & -0.605 \\
\hline & $(0.025)$ & $(0.146)$ & $(1.032)$ \\
\hline \multirow[t]{2}{*}{ Age: $50-59$} & $0.047^{*}$ & 0.083 & -0.651 \\
\hline & $(0.024)$ & $(0.145)$ & $(1.012)$ \\
\hline \multirow[t]{2}{*}{ Age: $60+$} & 0.037 & 0.076 & -1.294 \\
\hline & $(0.031)$ & $(0.2)$ & $(1.272)$ \\
\hline \multirow[t]{2}{*}{ Income: Lower Middle } & 0.038 & $0.352^{* *}$ & 0.482 \\
\hline & $(0.03)$ & $(0.173)$ & $(1.266)$ \\
\hline \multirow[t]{2}{*}{ Income: Middle } & $0.049^{*}$ & $0.377^{* *}$ & -0.132 \\
\hline & $(0.029)$ & $(0.17)$ & $(1.193)$ \\
\hline \multirow[t]{2}{*}{ Income: High } & $0.065^{* *}$ & 0.118 & -0.452 \\
\hline & $(0.028)$ & $(0.168)$ & $(1.158)$ \\
\hline \multirow[t]{2}{*}{ Education: High } & $0.121^{* * *}$ & $0.323^{* * *}$ & -0.101 \\
\hline & $(0.016)$ & $(0.098)$ & $(0.684)$ \\
\hline \multirow[t]{2}{*}{ Reciprocity: High } & $0.108^{* * *}$ & $0.533^{* * *}$ & $-2.471^{* * *}$ \\
\hline & $(0.015)$ & $(0.09)$ & $(0.647)$ \\
\hline \multirow[t]{2}{*}{ Altruism: High } & $0.093^{* * *}$ & $0.510^{* * *}$ & $3.550^{* * *}$ \\
\hline & $(0.017)$ & $(0.102)$ & $(0.723)$ \\
\hline \multirow[t]{2}{*}{ GHG Emissions: High } & $-0.066^{* * *}$ & $-0.369^{* * *}$ & $-2.209^{* * *}$ \\
\hline & $(0.015)$ & $(0.093)$ & $(0.647)$ \\
\hline \multirow[t]{2}{*}{ Car Ownership } & $-0.038^{*}$ & $-0.379 * * *$ & -0.961 \\
\hline & $(0.02)$ & $(0.121)$ & $(0.864)$ \\
\hline \multirow[t]{2}{*}{ Germany } & $0.046^{* *}$ & -0.069 & -0.753 \\
\hline & $(0.021)$ & $(0.116)$ & $(0.99)$ \\
\hline \multirow[t]{2}{*}{ United Kingdom } & $-0.096^{* * *}$ & $-0.928^{* * *}$ & $-5.388 * * *$ \\
\hline & $(0.021)$ & $(0.113)$ & $(0.923)$ \\
\hline \multirow[t]{2}{*}{ United States } & $-0.253^{* * *}$ & $-1.587^{* * *}$ & $-3.017^{* * *}$ \\
\hline & $(0.022)$ & $(0.134)$ & $(0.994)$ \\
\hline \multirow[t]{2}{*}{ Constant } & $0.567 * * *$ & $6.609 * * *$ & $22.103^{* * *}$ \\
\hline & $(0.039)$ & $(0.226)$ & $(1.683)$ \\
\hline Observations & 4008 & 4009 & 4009 \\
\hline R-squared & 0.096 & 0.087 & 0.023 \\
\hline
\end{tabular}

Table A-9: Support for Climate Cooperation: Norms and Interests (Car Ownership). This table reports OLS regression coefficients and robust standard errors (in parentheses). $* * *$ $p<.01,{ }^{* *} p<.05,{ }^{*} p<.10$. Reference groups are: Sex: Male, Age: 18-29, Income: Low, Education: Low, Reciprocity: Low, Altruism: Low, GHG (CO2 equivalent) Emissions: Low, Car: No ownership, Country: France. The sample is employed respondents in the pooled data for France, Germany, the United Kingdom, and the United States. 


\begin{tabular}{|c|c|c|c|}
\hline Dependent Variable & $\begin{array}{c}\text { Support for } \\
\text { Climate Cooperation }\end{array}$ & $\begin{array}{c}\text { Importance of } \mathrm{CO} 2 \\
\text { Reductions }\end{array}$ & $\begin{array}{l}\text { Environment: } \\
\text { Willingness to Pay }\end{array}$ \\
\hline Model & $(1)$ & $(2)$ & (3) \\
\hline \multirow[t]{2}{*}{ Female } & $-0.028^{*}$ & $0.455^{* * *}$ & $1.488^{* *}$ \\
\hline & $(0.014)$ & $(0.086)$ & $(0.622)$ \\
\hline \multirow[t]{2}{*}{ Age: 30-39 } & 0.037 & 0.204 & -0.069 \\
\hline & $(0.024)$ & $(0.135)$ & $(1.036)$ \\
\hline \multirow[t]{2}{*}{ Age: $40-49$} & 0.032 & -0.018 & -0.605 \\
\hline & $(0.024)$ & $(0.141)$ & $(1.027)$ \\
\hline \multirow{2}{*}{ Age: $50-59$} & $0.045^{*}$ & 0.060 & -0.745 \\
\hline & $(0.024)$ & $(0.141)$ & (1.003) \\
\hline \multirow[t]{2}{*}{ Age: $60+$} & 0.049 & 0.169 & -1.275 \\
\hline & $(0.030)$ & $(0.189)$ & (1.268) \\
\hline \multirow[t]{2}{*}{ Income: Lower Middle } & 0.034 & $0.316^{*}$ & 0.394 \\
\hline & $(0.030)$ & $(0.170)$ & $(1.273)$ \\
\hline \multirow{2}{*}{ Income: Middle } & $0.056^{*}$ & $0.426^{* * *}$ & -0.176 \\
\hline & $(0.029)$ & $(0.164)$ & (1.199) \\
\hline \multirow[t]{2}{*}{ Income: High } & $0.078^{* * *}$ & 0.215 & -0.471 \\
\hline & $(0.028)$ & $(0.161)$ & $(1.168)$ \\
\hline \multirow[t]{2}{*}{ Education: High } & $0.123^{* * *}$ & $0.341^{* * *}$ & -0.087 \\
\hline & $(0.016)$ & $(0.096)$ & $(0.685)$ \\
\hline \multirow[t]{2}{*}{ Reciprocity: High } & $0.108^{* * *}$ & $0.538^{* * *}$ & $-2.452^{* * *}$ \\
\hline & $(0.015)$ & $(0.088)$ & $(0.646)$ \\
\hline \multirow{2}{*}{ Altruism: High } & $0.089^{* * *}$ & $0.479 * * *$ & $3.521^{* * *}$ \\
\hline & $(0.016)$ & $(0.097)$ & $(0.723)$ \\
\hline \multirow[t]{2}{*}{ GHG Emissions: High } & $-0.061^{* * *}$ & $-0.334^{* * *}$ & $-2.207^{* * *}$ \\
\hline & $(0.015)$ & $(0.089)$ & $(0.642)$ \\
\hline \multirow[t]{2}{*}{ Ideology: Right } & $-0.198^{* * *}$ & $-1.670^{* * *}$ & $-1.815^{* *}$ \\
\hline & $(0.016)$ & $(0.099)$ & $(0.710)$ \\
\hline \multirow[t]{2}{*}{ Germany } & 0.023 & $-0.253^{* *}$ & -0.912 \\
\hline & $(0.022)$ & $(0.118)$ & $(0.991)$ \\
\hline \multirow[t]{2}{*}{ United Kingdom } & $-0.094^{* * *}$ & $-0.900^{* * *}$ & $-5.280^{* * *}$ \\
\hline & $(0.021)$ & $(0.112)$ & $(0.922)$ \\
\hline \multirow[t]{2}{*}{ United States } & $-0.236^{* * *}$ & $-1.441^{* * *}$ & $-2.863^{* * *}$ \\
\hline & $(0.022)$ & $(0.128)$ & $(1.001)$ \\
\hline \multirow[t]{2}{*}{ Constant } & $0.590 * * *$ & $6.767^{* * *}$ & $21.941^{* * *}$ \\
\hline & $(0.037)$ & $(0.215)$ & $(1.611)$ \\
\hline Observations & 4,008 & 4,009 & 4,009 \\
\hline R-squared & 0.130 & 0.152 & 0.025 \\
\hline
\end{tabular}

Table A-10: Support for Climate Cooperation: Norms and Interests (Political Ideology). This table reports OLS regression coefficients and robust standard errors (in parentheses). *** $p<.01,{ }^{* *} p<.05,{ }^{*} p<.10$. Reference groups are: Sex: Male, Age: 18-29, Income: Low, Education: Low, Reciprocity: Low, Altruism: Low, GHG (CO2 equivalent) Emissions: Low, Ideology: Left, Country: France. The sample is employed respondents in the pooled data for France, Germany, the United Kingdom, and the United States. 


\begin{tabular}{|c|c|c|c|c|c|}
\hline Dependent Variable & \multicolumn{5}{|c|}{ Support for Climate Cooperation } \\
\hline Scale & Binary & 5 points & Binary & Binary & Binary \\
\hline Model & Full & Full & Full & Full & Employed only \\
\hline Female & $\begin{array}{c}-0.035^{* * *} \\
(0.010)\end{array}$ & $\begin{array}{c}0.003 \\
(0.025)\end{array}$ & $\begin{array}{c}-0.031^{* * *} \\
(0.010)\end{array}$ & $\begin{array}{c}-0.035^{* * *} \\
(0.010)\end{array}$ & $\begin{array}{c}-0.070^{* * *} \\
(0.012)\end{array}$ \\
\hline Age: 30-39 & $\begin{array}{c}0.014 \\
(0.019)\end{array}$ & $\begin{array}{c}0.003 \\
(0.043)\end{array}$ & $\begin{array}{c}0.007 \\
(0.019)\end{array}$ & $\begin{array}{c}0.013 \\
(0.019)\end{array}$ & $\begin{array}{c}0.019 \\
(0.021)\end{array}$ \\
\hline Age: $40-49$ & $\begin{array}{c}0.011 \\
(0.019)\end{array}$ & $\begin{array}{l}-0.040 \\
(0.043)\end{array}$ & $\begin{array}{c}0.006 \\
(0.018)\end{array}$ & $\begin{array}{c}0.011 \\
(0.019)\end{array}$ & $\begin{array}{c}0.034 \\
(0.021)\end{array}$ \\
\hline Age: $50-59$ & $\begin{array}{c}0.055^{* * *} \\
(0.017)\end{array}$ & $\begin{array}{c}0.055 \\
(0.041)\end{array}$ & $\begin{array}{c}0.052^{* * *} \\
(0.017)\end{array}$ & $\begin{array}{c}0.054^{* * *} \\
(0.017)\end{array}$ & $\begin{array}{l}0.040^{* *} \\
(0.020)\end{array}$ \\
\hline Age: $60+$ & $\begin{array}{c}0.045^{* *} \\
(0.018)\end{array}$ & $\begin{array}{l}-0.023 \\
(0.042)\end{array}$ & $\begin{array}{l}0.039^{*} \\
(0.021)\end{array}$ & $\begin{array}{c}0.042^{* *} \\
(0.021)\end{array}$ & $\begin{array}{c}0.034 \\
(0.025)\end{array}$ \\
\hline Income: Lower Middle & $\begin{array}{c}0.025 \\
(0.017)\end{array}$ & $\begin{array}{c}0.038 \\
(0.039)\end{array}$ & $\begin{array}{c}0.021 \\
(0.017)\end{array}$ & $\begin{array}{c}0.025 \\
(0.017)\end{array}$ & $\begin{array}{c}0.006 \\
(0.025)\end{array}$ \\
\hline Income: Middle & $\begin{array}{c}0.035^{* *} \\
(0.017)\end{array}$ & $\begin{array}{c}0.028 \\
(0.039)\end{array}$ & $\begin{array}{c}0.035 * * \\
(0.017)\end{array}$ & $\begin{array}{c}0.035^{* *} \\
(0.017)\end{array}$ & $\begin{array}{c}0.017 \\
(0.024)\end{array}$ \\
\hline Income: High & $\begin{array}{c}0.038^{* *} \\
(0.016)\end{array}$ & $\begin{array}{l}-0.002 \\
(0.039)\end{array}$ & $\begin{array}{c}0.037^{* *} \\
(0.016)\end{array}$ & $\begin{array}{c}0.038 * * \\
(0.017)\end{array}$ & $\begin{array}{c}0.059 * * \\
(0.023)\end{array}$ \\
\hline Education: High & $\begin{array}{c}0.119^{* * *} \\
(0.011)\end{array}$ & $\begin{array}{c}0.287^{* * * *} \\
(0.027)\end{array}$ & $\begin{array}{c}0.128^{* * *} \\
(0.011)\end{array}$ & $\begin{array}{c}0.119^{* * *} \\
(0.011)\end{array}$ & $\begin{array}{c}0.092^{* * *} \\
(0.014)\end{array}$ \\
\hline Reciprocity: High & $\begin{array}{c}0.099^{* * *} \\
(0.011)\end{array}$ & $\begin{array}{c}0.205^{* * *} \\
(0.026)\end{array}$ & $\begin{array}{c}0.100^{* * *} \\
(0.010)\end{array}$ & $\begin{array}{c}0.099^{* * *} \\
(0.011)\end{array}$ & $\begin{array}{c}0.059^{* * *} \\
(0.012)\end{array}$ \\
\hline Altruism: High & $\begin{array}{c}0.085^{* * *} \\
(0.012)\end{array}$ & $\begin{array}{c}0.205^{* * *} \\
(0.030)\end{array}$ & $\begin{array}{c}0.085^{* * *} \\
(0.012)\end{array}$ & $\begin{array}{c}0.085^{* * *} \\
(0.012)\end{array}$ & $\begin{array}{c}0.046^{* * *} \\
(0.013)\end{array}$ \\
\hline GHG Emissions: High & $\begin{array}{c}-0.069^{* * *} \\
(0.015)\end{array}$ & $\begin{array}{c}-0.200 * * * \\
(0.037)\end{array}$ & & $\begin{array}{c}-0.069 * * * \\
(0.015)\end{array}$ & $\begin{array}{c}-0.030^{* *} \\
(0.013)\end{array}$ \\
\hline GHG Emissions: Missing & $\begin{array}{c}-0.025^{*} \\
(0.014)\end{array}$ & $\begin{array}{c}-0.043 \\
(0.033)\end{array}$ & & $\begin{array}{c}-0.028^{*} \\
(0.015)\end{array}$ & \\
\hline Paid Work & & & $\begin{array}{l}-0.005 \\
(0.014)\end{array}$ & & \\
\hline Unemployed & & & $\begin{array}{c}0.010 \\
(0.022)\end{array}$ & $\begin{array}{c}0.008 \\
(0.022)\end{array}$ & \\
\hline Retired & & & $\begin{array}{c}0.009 \\
(0.020)\end{array}$ & $\begin{array}{c}0.007 \\
(0.020)\end{array}$ & \\
\hline C02 Reductions: Important & & & & & $\begin{array}{c}0.092^{* * *} \\
(0.002)\end{array}$ \\
\hline Ideology: Right & & & & & $\begin{array}{c}-0.045^{* * *} \\
(0.014)\end{array}$ \\
\hline Germany & $\begin{array}{c}0.040^{* * *} \\
(0.014)\end{array}$ & $\begin{array}{c}0.034 \\
(0.032)\end{array}$ & $\begin{array}{c}0.038^{* * *} \\
(0.014)\end{array}$ & $\begin{array}{c}0.041^{* * *} \\
(0.015)\end{array}$ & $\begin{array}{c}0.047^{* *} \\
(0.020)\end{array}$ \\
\hline United Kingdom & $\begin{array}{c}-0.075 * * * \\
(0.015)\end{array}$ & $\begin{array}{c}-0.280^{* * *} \\
(0.033)\end{array}$ & $\begin{array}{c}-0.066^{* * *} \\
(0.015)\end{array}$ & $\begin{array}{c}-0.075^{* * *} \\
(0.015)\end{array}$ & $\begin{array}{l}-0.012 \\
(0.019)\end{array}$ \\
\hline United States & $\begin{array}{c}-0.217^{* * *} \\
(0.015)\end{array}$ & $\begin{array}{c}-0.725^{* * *} \\
(0.036)\end{array}$ & $\begin{array}{c}-0.214^{* * *} \\
(0.015)\end{array}$ & $\begin{array}{c}-0.217^{* * *} \\
(0.015)\end{array}$ & $\begin{array}{c}-0.103^{* * *} \\
(0.019)\end{array}$ \\
\hline Constant & $\begin{array}{c}0.563^{* * *} \\
(0.025)\end{array}$ & $\begin{array}{c}3.740 * * * \\
(0.059)\end{array}$ & $\begin{array}{c}0.529 * * * \\
(0.023)\end{array}$ & $\begin{array}{c}0.563^{* * *} \\
(0.025)\end{array}$ & $\begin{array}{l}-0.030 \\
(0.035)\end{array}$ \\
\hline Observations & 8,329 & 8,329 & 8,499 & 8,329 & 4,008 \\
\hline R-squared & 0.075 & 0.092 & 0.072 & 0.075 & 0.392 \\
\hline
\end{tabular}

Table A-11: Support for Climate Cooperation: GHG Emissions Missingness and Employment Status. This table reports OLS regression coefficients and robust standard errors (in parentheses). ${ }^{* * *} p<.01,{ }^{* *} p<.05,{ }^{*} p<.10$. Reference groups are: Sex: Male, Age: 18-29, Income: Low, Education: Low, Reciprocity: Low, Altruism: Low, GHG Emissions: Low, Employment: Other, C02 Reductions: Unimportant, Ideology: Left, Country: France. The sample is all respondents in France, Germany, the United Kingdom, and the United States except for Model 5 (employed only). 13 


\begin{tabular}{|c|c|c|c|c|}
\hline \multirow[t]{2}{*}{ Dependent Variable } & \multicolumn{4}{|c|}{ Support for Climate Cooperation } \\
\hline & $(1)$ & $(2)$ & $(3)$ & $(4)$ \\
\hline Country & France & Germany & United Kingdom & United States \\
\hline \multirow[t]{2}{*}{ Female } & $-0.119^{*}$ & $-0.138^{* *}$ & 0.034 & $0.237^{* * *}$ \\
\hline & $(0.068)$ & $(0.063)$ & $(0.062)$ & $(0.088)$ \\
\hline \multirow[t]{2}{*}{ Age: $30-39$} & -0.008 & 0.110 & 0.051 & -0.012 \\
\hline & $(0.112)$ & $(0.105)$ & $(0.095)$ & $(0.146)$ \\
\hline \multirow[t]{2}{*}{ Age: $40-49$} & $0.320^{* * *}$ & $0.180^{*}$ & -0.163 & $-0.267^{*}$ \\
\hline & $(0.113)$ & $(0.108)$ & $(0.099)$ & $(0.137)$ \\
\hline \multirow[t]{2}{*}{ Age: $50-59$} & $0.260 * *$ & $0.273^{* * *}$ & -0.126 & -0.125 \\
\hline & $(0.113)$ & $(0.105)$ & $(0.109)$ & $(0.123)$ \\
\hline \multirow[t]{2}{*}{ Age: $60+$} & $0.436^{* *}$ & $0.367 * * *$ & 0.014 & $-0.299^{* *}$ \\
\hline & $(0.190)$ & $(0.132)$ & $(0.152)$ & $(0.150)$ \\
\hline \multirow[t]{2}{*}{ Income: Lower Middle } & 0.004 & 0.161 & 0.102 & -0.038 \\
\hline & $(0.119)$ & $(0.272)$ & $(0.110)$ & $(0.167)$ \\
\hline \multirow[t]{2}{*}{ Income: Middle } & $0.204^{*}$ & 0.047 & 0.039 & -0.185 \\
\hline & $(0.112)$ & $(0.273)$ & $(0.104)$ & $(0.160)$ \\
\hline \multirow[t]{2}{*}{ Income: High } & $0.185^{*}$ & 0.153 & 0.063 & $-0.260^{*}$ \\
\hline & $(0.106)$ & $(0.272)$ & $(0.102)$ & $(0.155)$ \\
\hline \multirow[t]{2}{*}{ Education: High } & $0.229 * * *$ & $0.220 * * *$ & $0.352^{* * *}$ & $0.408^{* * *}$ \\
\hline & $(0.072)$ & $(0.070)$ & $(0.066)$ & $(0.099)$ \\
\hline \multirow[t]{2}{*}{ Reciprocity: High } & $0.305^{* * *}$ & $0.252^{* * *}$ & $0.176^{* * *}$ & $0.183^{* *}$ \\
\hline & $(0.068)$ & $(0.063)$ & $(0.063)$ & $(0.089)$ \\
\hline \multirow[t]{2}{*}{ Altruism: High } & 0.104 & 0.124 & $0.318^{* * *}$ & $0.332^{* * *}$ \\
\hline & $(0.079)$ & $(0.082)$ & $(0.065)$ & $(0.090)$ \\
\hline \multirow[t]{2}{*}{ GHG Emissions: High } & -0.053 & -0.097 & $-0.136^{* *}$ & $-0.426^{* * *}$ \\
\hline & $(0.068)$ & $(0.063)$ & $(0.067)$ & $(0.092)$ \\
\hline \multirow[t]{2}{*}{ Constant } & $3.431^{* * *}$ & $3.573^{* * *}$ & $3.398^{* * *}$ & $3.183^{* * *}$ \\
\hline & $(0.149)$ & $(0.283)$ & $(0.132)$ & $(0.200)$ \\
\hline Observations & 816 & 929 & 1,141 & 1,122 \\
\hline R-squared & 0.074 & 0.055 & 0.079 & 0.088 \\
\hline
\end{tabular}

Table A-12: Support for Climate Cooperation: Norms and Interests by Country. This table reports OLS regression coefficients and robust standard errors (in parentheses). ${ }^{* * *} p<.01$, ${ }^{* *} p<.05,{ }^{*} p<.10$. Reference groups are: Sex: Male, Age: 18-29, Income: Low, Education: Low, Reciprocity: Low, Altruism: Low, GHG (CO2 equivalent) Emissions: Low. The sample is employed respondents in the data for France, Germany, the United Kingdom, and the United States. 


\begin{tabular}{|c|c|c|c|c|c|c|}
\hline \multirow{3}{*}{$\begin{array}{r}\text { Dependent Variable } \\
\text { Model }\end{array}$} & \multicolumn{4}{|c|}{$\begin{array}{l}\text { Support for Climate Cooperation } \\
\qquad(\text { scale } 1-5)\end{array}$} & \multirow{3}{*}{$\begin{array}{c}\text { Importance of } \mathrm{CO} 2 \\
\text { Reductions }\end{array}$} & \multirow{3}{*}{$\begin{array}{c}\text { Environment: } \\
\text { Willingness to Pay } \\
(6)\end{array}$} \\
\hline & $(1)$ & $(2)$ & $(3)$ & $(4)$ & & \\
\hline & Socio-demographics & Norms & Interest & Full & & \\
\hline \multirow[t]{2}{*}{ Female } & 0.016 & 0.008 & -0.009 & -0.016 & $0.710^{* * *}$ & $2.202^{* * *}$ \\
\hline & $(0.034)$ & $(0.034)$ & $(0.035)$ & $(0.035)$ & $(0.120)$ & $(0.680)$ \\
\hline \multirow[t]{2}{*}{ Age: 30-39 } & -0.013 & 0.005 & -0.006 & 0.012 & 0.126 & -0.130 \\
\hline & $(0.056)$ & $(0.056)$ & $(0.056)$ & $(0.056)$ & $(0.186)$ & $(1.117)$ \\
\hline \multirow[t]{2}{*}{ Age: $40-49$} & -0.069 & -0.030 & -0.054 & -0.015 & -0.141 & -1.114 \\
\hline & $(0.056)$ & $(0.056)$ & $(0.056)$ & $(0.056)$ & $(0.195)$ & $(1.122)$ \\
\hline \multirow[t]{2}{*}{ Age: 50-59 } & 0.002 & 0.055 & 0.011 & 0.062 & 0.087 & -0.855 \\
\hline & $(0.056)$ & $(0.056)$ & $(0.056)$ & $(0.056)$ & $(0.195)$ & $(1.098)$ \\
\hline \multirow[t]{2}{*}{ Age: $60+$} & 0.043 & 0.086 & 0.051 & 0.093 & 0.125 & -1.636 \\
\hline & $(0.078)$ & $(0.079)$ & $(0.078)$ & $(0.079)$ & $(0.275)$ & $(1.407)$ \\
\hline \multirow[t]{2}{*}{ Income: Lower Middle } & 0.080 & 0.066 & 0.087 & 0.073 & 0.321 & 0.783 \\
\hline & $(0.064)$ & $(0.064)$ & $(0.065)$ & $(0.065)$ & $(0.231)$ & $(1.404)$ \\
\hline \multirow[t]{2}{*}{ Income: Middle } & 0.079 & 0.063 & 0.077 & 0.062 & 0.355 & 0.016 \\
\hline & $(0.062)$ & $(0.062)$ & $(0.062)$ & $(0.063)$ & $(0.227)$ & $(1.323)$ \\
\hline \multirow[t]{2}{*}{ Income: High } & 0.078 & 0.057 & 0.081 & 0.060 & -0.040 & -0.486 \\
\hline & $(0.060)$ & $(0.060)$ & $(0.061)$ & $(0.061)$ & $(0.221)$ & $(1.291)$ \\
\hline \multirow[t]{2}{*}{ Education: High } & $0.349^{* * *}$ & $0.329 * * *$ & $0.322^{* * *}$ & $0.303^{* * *}$ & $0.394^{* * *}$ & 0.232 \\
\hline & $(0.036)$ & $(0.037)$ & $(0.037)$ & $(0.037)$ & $(0.132)$ & $(0.761)$ \\
\hline \multirow[t]{2}{*}{ Reciprocity: High } & & $0.235^{* * *}$ & & $0.230^{* * *}$ & $0.707^{* * *}$ & $-1.977 * * *$ \\
\hline & & $(0.035)$ & & $(0.035)$ & $(0.122)$ & $(0.713)$ \\
\hline \multirow[t]{2}{*}{ Altruism: High } & & $0.233^{* * *}$ & & $0.231^{* * *}$ & $0.690^{* * *}$ & $4.308^{* * *}$ \\
\hline & & $(0.042)$ & & $(0.042)$ & $(0.140)$ & $(0.788)$ \\
\hline \multirow[t]{2}{*}{ GHG Emissions: High } & & & $-0.199 * * *$ & $-0.190 * * *$ & $-0.516^{* * *}$ & $-2.466 * * *$ \\
\hline & & & $(0.036)$ & $(0.036)$ & $(0.124)$ & $(0.708)$ \\
\hline \multirow[t]{2}{*}{ Germany } & 0.068 & $0.095^{*}$ & 0.051 & 0.079 & 0.048 & -0.799 \\
\hline & $(0.049)$ & $(0.049)$ & $(0.049)$ & $(0.049)$ & $(0.161)$ & $(1.062)$ \\
\hline \multirow[t]{2}{*}{ United Kingdom } & $-0.199 * * *$ & $-0.217^{* * *}$ & $-0.237 * * *$ & $-0.254^{* * *}$ & $-1.085^{* * *}$ & $-5.813^{* * *}$ \\
\hline & $(0.045)$ & $(0.045)$ & $(0.046)$ & $(0.046)$ & $(0.150)$ & $(0.993)$ \\
\hline \multirow[t]{2}{*}{ United States } & $-0.614^{* * *}$ & $-0.640^{* * *}$ & $-0.644^{* * *}$ & $-0.668^{* * *}$ & $-1.890^{* * *}$ & $-4.567 * * *$ \\
\hline & $(0.052)$ & $(0.052)$ & $(0.052)$ & $(0.053)$ & $(0.183)$ & $(1.094)$ \\
\hline \multirow[t]{2}{*}{ Constant } & & & & & $6.625^{* * *}$ & $19.910^{* * *}$ \\
\hline & & & & & $(0.290)$ & $(1.769)$ \\
\hline Observations & 4,008 & 4,008 & 4,008 & 4,008 & 4,009 & 4,009 \\
\hline
\end{tabular}

Table A-13: Support for Climate Cooperation: Ordered Probit and Tobit Estimates. Models 1-4 report ordered probit results for Support for Climate Cooperation defined on a 5-point scale (see main text for description). Models 5 and 6 report tobit estimates for Importance of CO2 Reductions and Willingness to Pay for the Environment. The table shows coefficients and robust standard errors (in parentheses). ${ }^{* * *} p<.01,{ }^{* *} p<.05,{ }^{*} p<.10$. Reference groups are: Sex: Male, Age: 18-29, Income: Low, Education: Low, Reciprocity: Low, Altruism: Low, GHG Emissions: Low, Country: France. The sample is employed respondents in France, Germany, the United Kingdom, and the United States. 


\begin{tabular}{|c|c|c|c|}
\hline Dependent Variable & $\begin{array}{c}\text { Support for } \\
\text { Climate Cooperation }\end{array}$ & $\begin{array}{c}\text { Importance of CO2 } \\
\text { Reductions }\end{array}$ & $\begin{array}{c}\text { Environment: } \\
\text { Willingness to Pay }\end{array}$ \\
\hline Model & $(1)$ & $(2)$ & $(3)$ \\
\hline Female & $\begin{array}{l}-0.017 \\
(0.015)\end{array}$ & $\begin{array}{c}0.551^{* * *} \\
(0.090)\end{array}$ & $\begin{array}{c}1.615^{* * *} \\
(0.624)\end{array}$ \\
\hline Age: $30-39$ & $\begin{array}{c}0.027 \\
(0.025)\end{array}$ & $\begin{array}{c}0.113 \\
(0.139)\end{array}$ & $\begin{array}{l}-0.162 \\
(1.031)\end{array}$ \\
\hline Age: $40-49$ & $\begin{array}{c}0.017 \\
(0.025)\end{array}$ & $\begin{array}{l}-0.145 \\
(0.145)\end{array}$ & $\begin{array}{l}-0.734 \\
(1.020)\end{array}$ \\
\hline Age: $50-59$ & $\begin{array}{l}0.042^{*} \\
(0.024)\end{array}$ & $\begin{array}{c}0.028 \\
(0.144)\end{array}$ & $\begin{array}{l}-0.774 \\
(1.001)\end{array}$ \\
\hline Age: $60+$ & $\begin{array}{c}0.029 \\
(0.031)\end{array}$ & $\begin{array}{l}-0.000 \\
(0.199)\end{array}$ & $\begin{array}{l}-1.444 \\
(1.260)\end{array}$ \\
\hline Income: Lower Middle & $\begin{array}{c}0.033 \\
(0.030)\end{array}$ & $\begin{array}{l}0.304^{*} \\
(0.174)\end{array}$ & $\begin{array}{c}0.392 \\
(1.269)\end{array}$ \\
\hline Income: Middle & $\begin{array}{c}0.039 \\
(0.029)\end{array}$ & $\begin{array}{l}0.284^{*} \\
(0.169)\end{array}$ & $\begin{array}{l}-0.310 \\
(1.194)\end{array}$ \\
\hline Income: High & $\begin{array}{l}0.053^{*} \\
(0.028)\end{array}$ & $\begin{array}{c}0.006 \\
(0.166)\end{array}$ & $\begin{array}{l}-0.676 \\
(1.161)\end{array}$ \\
\hline Education: High & $\begin{array}{c}0.117^{* * *} \\
(0.016)\end{array}$ & $\begin{array}{c}0.293^{* * *} \\
(0.099)\end{array}$ & $\begin{array}{l}-0.119 \\
(0.688)\end{array}$ \\
\hline Reciprocity: High & $\begin{array}{c}0.108^{* * *} \\
(0.015)\end{array}$ & $\begin{array}{c}0.535^{* * *} \\
(0.090)\end{array}$ & $\begin{array}{c}-2.448^{* * *} \\
(0.646)\end{array}$ \\
\hline Altruism: High & $\begin{array}{c}0.095^{* * *} \\
(0.017)\end{array}$ & $\begin{array}{c}0.521^{* * *} \\
(0.102)\end{array}$ & $\begin{array}{c}3.562^{* * *} \\
(0.723)\end{array}$ \\
\hline GHG Emissions: High & $\begin{array}{c}-0.057^{* * *} \\
(0.016)\end{array}$ & $\begin{array}{c}-0.304^{* * *} \\
(0.097)\end{array}$ & $\begin{array}{c}-2.244^{* * *} \\
(0.711)\end{array}$ \\
\hline Public Sector Employment: High & $\begin{array}{l}0.028^{*} \\
(0.016)\end{array}$ & $\begin{array}{r}0.235^{* *} \\
(0.097)\end{array}$ & $\begin{array}{c}0.071 \\
(0.710)\end{array}$ \\
\hline Germany & $\begin{array}{l}0.052^{* *} \\
(0.021)\end{array}$ & $\begin{array}{l}-0.017 \\
(0.116)\end{array}$ & $\begin{array}{l}-0.676 \\
(0.996)\end{array}$ \\
\hline United Kingdom & $\begin{array}{c}-0.090 * * * \\
(0.021)\end{array}$ & $\begin{array}{c}-0.864^{* * *} \\
(0.111)\end{array}$ & $\begin{array}{c}-5.249 * * * \\
(0.923)\end{array}$ \\
\hline United States & $\begin{array}{c}-0.250^{* * *} \\
(0.022)\end{array}$ & $\begin{array}{c}-1.561^{* * *} \\
(0.134)\end{array}$ & $\begin{array}{c}-3.016 * * * \\
(1.000)\end{array}$ \\
\hline Constant & $0.533^{* * *}$ & $6.289 * * *$ & $21.492^{* * *}$ \\
\hline $\begin{array}{l}\text { Observations } \\
\text { R-squared }\end{array}$ & $\begin{array}{c}(0.038) \\
4,008 \\
0.096\end{array}$ & $\begin{array}{c}(0.219) \\
4,009 \\
0.086\end{array}$ & $\begin{array}{c}(1.646) \\
4,009 \\
0.023\end{array}$ \\
\hline
\end{tabular}

Table A-14: Support for Climate Cooperation (Public Sectors). This table reports OLS regression coefficients and robust standard errors (in parentheses). ${ }^{* * *} p<.01,{ }^{* *} p<.05$, ${ }^{*} p<.10$. Reference groups are: Sex: Male, Age: 18-29, Income: Low, Education: Low, Reciprocity: Low, Altruism: Low, GHG (CO2 equivalent) Emissions: Low, Public Sector Employment: Low Country: France. The sample is employed respondents in the pooled data for France, Germany, the United Kingdom, and the United States. Sectors with a large share of public employees are: Scientific and Technical Activities, Administration and Support Service, Public Administration and Defense, Education, Human Health and Social Work, Arts and Recreation. 


\begin{tabular}{|c|c|c|c|}
\hline Dependent Variable & $\begin{array}{c}\text { Support for } \\
\text { Climate Cooperation }\end{array}$ & $\begin{array}{c}\text { Importance of CO2 } \\
\text { Reductions }\end{array}$ & $\begin{array}{c}\text { Environment: } \\
\text { Willingness to Pay }\end{array}$ \\
\hline Model & $(1)$ & $(2)$ & $(3)$ \\
\hline Female & $\begin{array}{l}-0.014 \\
(0.015)\end{array}$ & $\begin{array}{c}0.580^{* * *} \\
(0.089)\end{array}$ & $\begin{array}{c}1.591^{* * *} \\
(0.617)\end{array}$ \\
\hline Age: $30-39$ & $\begin{array}{c}0.028 \\
(0.025)\end{array}$ & $\begin{array}{c}0.124 \\
(0.139)\end{array}$ & $\begin{array}{l}-0.174 \\
(1.032)\end{array}$ \\
\hline Age: $40-49$ & $\begin{array}{c}0.020 \\
(0.025)\end{array}$ & $\begin{array}{l}-0.127 \\
(0.146)\end{array}$ & $\begin{array}{l}-0.778 \\
(1.022)\end{array}$ \\
\hline Age: $50-59$ & $\begin{array}{l}0.043^{*} \\
(0.024)\end{array}$ & $\begin{array}{c}0.043 \\
(0.145)\end{array}$ & $\begin{array}{l}-0.834 \\
(1.003)\end{array}$ \\
\hline Age: $60+$ & $\begin{array}{c}0.032 \\
(0.031)\end{array}$ & $\begin{array}{c}0.028 \\
(0.199)\end{array}$ & $\begin{array}{l}-1.532 \\
(1.270)\end{array}$ \\
\hline Income: Lower Middle & $\begin{array}{c}0.034 \\
(0.030)\end{array}$ & $\begin{array}{l}0.317^{*} \\
(0.174)\end{array}$ & $\begin{array}{c}0.407 \\
(1.269)\end{array}$ \\
\hline Income: Middle & $\begin{array}{c}0.042 \\
(0.029)\end{array}$ & $\begin{array}{l}0.308^{*} \\
(0.169)\end{array}$ & $\begin{array}{l}-0.264 \\
(1.192)\end{array}$ \\
\hline Income: High & $\begin{array}{c}0.057^{* *} \\
(0.028)\end{array}$ & $\begin{array}{c}0.034 \\
(0.166)\end{array}$ & $\begin{array}{l}-0.665 \\
(1.157)\end{array}$ \\
\hline Education: High & $\begin{array}{c}0.120^{* * *} \\
(0.016)\end{array}$ & $\begin{array}{c}0.320^{* * *} \\
(0.098)\end{array}$ & $\begin{array}{l}-0.122 \\
(0.684)\end{array}$ \\
\hline Reciprocity: High & $\begin{array}{c}0.115^{* * *} \\
(0.018)\end{array}$ & $\begin{array}{c}0.526^{* * *} \\
(0.108)\end{array}$ & $\begin{array}{c}-1.754^{* *} \\
(0.772)\end{array}$ \\
\hline Altruism: High & $\begin{array}{c}0.104^{* * *} \\
(0.019)\end{array}$ & $\begin{array}{c}0.578^{* * *} \\
(0.118)\end{array}$ & $\begin{array}{c}3.125^{* * *} \\
(0.850)\end{array}$ \\
\hline GHG Emissions: High & $\begin{array}{c}-0.054^{* * *} \\
(0.020)\end{array}$ & $\begin{array}{c}-0.373^{* * *} \\
(0.124)\end{array}$ & $\begin{array}{c}-1.734^{* *} \\
(0.881)\end{array}$ \\
\hline GHG EmissionsXReciprocity & $\begin{array}{l}-0.023 \\
(0.033)\end{array}$ & $\begin{array}{c}0.049 \\
(0.204)\end{array}$ & $\begin{array}{l}-2.302^{*} \\
(1.321)\end{array}$ \\
\hline GHG EmissionsXAltruism & $\begin{array}{l}-0.001 \\
(0.000)\end{array}$ & $\begin{array}{l}-0.003 \\
(0.003)\end{array}$ & $\begin{array}{c}0.020 \\
(0.023) \\
\end{array}$ \\
\hline Germany & $\begin{array}{c}0.049^{* *} \\
(0.021)\end{array}$ & $\begin{array}{c}-0.040 \\
(0.116)\end{array}$ & $\begin{array}{c}-0.673 \\
(0.993)\end{array}$ \\
\hline United Kingdom & $\begin{array}{c}-0.090^{* * *} \\
(0.021)\end{array}$ & $\begin{array}{c}-0.873^{* * *} \\
(0.112)\end{array}$ & $\begin{array}{c}-5.228^{* * *} \\
(0.920)\end{array}$ \\
\hline United States & $\begin{array}{c}-0.253^{* * *} \\
(0.022)\end{array}$ & $\begin{array}{c}-1.583^{* * *} \\
(0.134)\end{array}$ & $\begin{array}{c}-3.098^{* * *} \\
(0.990)\end{array}$ \\
\hline Constant & $\begin{array}{c}0.537^{* * *} * \\
(0.038) \\
\end{array}$ & $\begin{array}{c}6.364^{* * *} \\
(0.221) \\
\end{array}$ & $\begin{array}{c}21.308^{* * *} \\
(1.658) \\
\end{array}$ \\
\hline $\begin{array}{l}\text { Observations } \\
\text { R-squared }\end{array}$ & $\begin{array}{l}4,007 \\
0.095\end{array}$ & $\begin{array}{l}4,008 \\
0.085\end{array}$ & $\begin{array}{l}4,008 \\
0.024\end{array}$ \\
\hline
\end{tabular}

Table A-15: Support for Climate Cooperation and Environmentalism: Norms, Interests, and their Interactions. This table reports OLS regression coefficients and robust standard errors (in parentheses). ${ }^{* * *} p<.01,{ }^{* *} p<.05,{ }^{*} p<.10$. Reference groups are: Sex: Male, Age: 18-29, Income: Low, Education: Low, Reciprocity: Low, Altruism: Low, GHG Emissions: Low, Country: France. The sample is employed respondents in the pooled data for France, Germany, the United Kingdom, and the United States. 


\begin{tabular}{|c|c|c|c|}
\hline Dependent Variable & \multicolumn{3}{|c|}{ Support for Climate Cooperation } \\
\hline Scale & Binary & 5 points & Binary \\
\hline Female & $\begin{array}{c}-0.035^{* * *} \\
(0.010)\end{array}$ & $\begin{array}{c}0.003 \\
(0.025)\end{array}$ & $\begin{array}{c}-0.035^{* * *} \\
(0.010)\end{array}$ \\
\hline Age: $30-39$ & $\begin{array}{c}0.014 \\
(0.019)\end{array}$ & $\begin{array}{c}0.003 \\
(0.043)\end{array}$ & $\begin{array}{c}0.013 \\
(0.019)\end{array}$ \\
\hline Age: $40-49$ & $\begin{array}{c}0.011 \\
(0.019)\end{array}$ & $\begin{array}{l}-0.040 \\
(0.043)\end{array}$ & $\begin{array}{c}0.011 \\
(0.019)\end{array}$ \\
\hline Age: $50-59$ & $\begin{array}{c}0.055^{* * *} \\
(0.017)\end{array}$ & $\begin{array}{c}0.055 \\
(0.041)\end{array}$ & $\begin{array}{c}0.054^{* * *} \\
(0.017)\end{array}$ \\
\hline Age: $60+$ & $\begin{array}{c}0.045^{* *} \\
(0.018)\end{array}$ & $\begin{array}{l}-0.023 \\
(0.042)\end{array}$ & $\begin{array}{c}0.042^{* *} \\
(0.021)\end{array}$ \\
\hline Income: Lower Middle & $\begin{array}{c}0.025 \\
(0.017)\end{array}$ & $\begin{array}{c}0.038 \\
(0.039)\end{array}$ & $\begin{array}{c}0.025 \\
(0.017)\end{array}$ \\
\hline Income: Middle & $\begin{array}{c}0.035 * * \\
(0.017)\end{array}$ & $\begin{array}{c}0.028 \\
(0.039)\end{array}$ & $\begin{array}{c}0.035^{* *} \\
(0.017)\end{array}$ \\
\hline Income: High & $\begin{array}{c}0.038 * * \\
(0.016)\end{array}$ & $\begin{array}{l}-0.002 \\
(0.039)\end{array}$ & $\begin{array}{c}0.038^{* *} \\
(0.017)\end{array}$ \\
\hline Education: High & $\begin{array}{c}0.119^{* * *} \\
(0.011)\end{array}$ & $\begin{array}{c}0.287^{* * *} \\
(0.027)\end{array}$ & $\begin{array}{c}0.119^{* * *} \\
(0.011)\end{array}$ \\
\hline Reciprocity: High & $\begin{array}{c}0.099^{* * *} \\
(0.011)\end{array}$ & $\begin{array}{c}0.205^{* * *} \\
(0.026)\end{array}$ & $\begin{array}{c}0.099^{* * *} \\
(0.011)\end{array}$ \\
\hline Altruism: High & $\begin{array}{c}0.085^{* * *} \\
(0.012)\end{array}$ & $\begin{array}{c}0.205^{* * *} \\
(0.030)\end{array}$ & $\begin{array}{c}0.085^{* * *} \\
(0.012)\end{array}$ \\
\hline GHG Emissions: Low & $\begin{array}{l}0.025^{*} \\
(0.014)\end{array}$ & $\begin{array}{c}0.043 \\
(0.033)\end{array}$ & $\begin{array}{l}0.028^{*} \\
(0.015)\end{array}$ \\
\hline GHG Emissions: High & $\begin{array}{c}-0.044^{* * *} \\
(0.015)\end{array}$ & $\begin{array}{c}-0.157^{* * *} \\
(0.036)\end{array}$ & $\begin{array}{c}-0.041^{* *} \\
(0.017)\end{array}$ \\
\hline Unemployed & & & $\begin{array}{c}0.008 \\
(0.022)\end{array}$ \\
\hline Retired & & & $\begin{array}{c}0.007 \\
(0.020)\end{array}$ \\
\hline Germany & $\begin{array}{c}0.040^{* * *} \\
(0.014)\end{array}$ & $\begin{array}{c}0.034 \\
(0.032)\end{array}$ & $\begin{array}{c}0.041^{* * *} \\
(0.015)\end{array}$ \\
\hline United Kingdom & $\begin{array}{c}-0.075^{* * *} \\
(0.015)\end{array}$ & $\begin{array}{c}-0.280^{* * *} \\
(0.033)\end{array}$ & $\begin{array}{c}-0.075 * * * \\
(0.015)\end{array}$ \\
\hline United States & $\begin{array}{c}-0.217^{* * *} \\
(0.015)\end{array}$ & $\begin{array}{c}-0.725^{* * *} \\
(0.036)\end{array}$ & $\begin{array}{c}-0.217^{* * *} \\
(0.015)\end{array}$ \\
\hline Constant & $\begin{array}{c}0.538^{* * *} \\
(0.022) \\
\end{array}$ & $\begin{array}{c}3.696^{* * *} \\
(0.051)\end{array}$ & $\begin{array}{c}0.535^{* * *} \\
(0.023)\end{array}$ \\
\hline $\begin{array}{l}\text { Observations } \\
\text { R-squared }\end{array}$ & $\begin{array}{l}8,329 \\
0.075\end{array}$ & $\begin{array}{l}8,329 \\
0.092\end{array}$ & $\begin{array}{l}8,329 \\
0.075\end{array}$ \\
\hline
\end{tabular}

Table A-16: Support for Climate Cooperation: GHG Emissions Missingness and Employment Status (Unemployed as Reference Group). This table reports OLS regression coefficients and robust standard errors (in parentheses). ${ }^{* * *} p<.01$, ${ }^{* *} p<.05,{ }^{*} p<.10$. Reference groups are: Sex: Male, Age: 18-29, Income: Low, Education: Low, Reciprocity: Low, Altruism: Low, GHG (CO2 equivalent) Emissions: Missing, Country: France. The sample is all respondents in France, Germany, the United Kingdom, and the United States. 


\begin{tabular}{|c|c|c|c|}
\hline Dependent Variable & \multicolumn{3}{|c|}{ Support for Climate Cooperation } \\
\hline GHG Emissions Measure & Continuous & Tertiles & Quartiles \\
\hline Model & $(1)$ & $(2)$ & $(3)$ \\
\hline Female & $\begin{array}{l}-0.013 \\
(0.015)\end{array}$ & $\begin{array}{l}-0.017 \\
(0.015)\end{array}$ & $\begin{array}{l}-0.016 \\
(0.015)\end{array}$ \\
\hline Age: $30-39$ & $\begin{array}{c}0.029 \\
(0.025)\end{array}$ & $\begin{array}{c}0.028 \\
(0.025)\end{array}$ & $\begin{array}{c}0.028 \\
(0.025)\end{array}$ \\
\hline Age: $40-49$ & $\begin{array}{c}0.018 \\
(0.025)\end{array}$ & $\begin{array}{c}0.016 \\
(0.025)\end{array}$ & $\begin{array}{c}0.019 \\
(0.025)\end{array}$ \\
\hline Age: $50-59$ & $\begin{array}{l}0.044^{*} \\
(0.024)\end{array}$ & $\begin{array}{l}0.042^{*} \\
(0.024)\end{array}$ & $\begin{array}{l}0.043^{*} \\
(0.024)\end{array}$ \\
\hline Age: $60+$ & $\begin{array}{c}0.031 \\
(0.031)\end{array}$ & $\begin{array}{c}0.029 \\
(0.031)\end{array}$ & $\begin{array}{c}0.031 \\
(0.031)\end{array}$ \\
\hline Income: Lower Middle & $\begin{array}{c}0.031 \\
(0.030)\end{array}$ & $\begin{array}{c}0.031 \\
(0.030)\end{array}$ & $\begin{array}{c}0.031 \\
(0.030)\end{array}$ \\
\hline Income: Middle & $\begin{array}{c}0.042 \\
(0.029)\end{array}$ & $\begin{array}{c}0.040 \\
(0.029)\end{array}$ & $\begin{array}{c}0.041 \\
(0.029)\end{array}$ \\
\hline Income: High & $\begin{array}{c}0.057^{* *} \\
(0.028)\end{array}$ & $\begin{array}{c}0.054^{*} \\
(0.028)\end{array}$ & $\begin{array}{c}0.056^{* *} \\
(0.028)\end{array}$ \\
\hline Education: High & $\begin{array}{c}0.125^{* * *} \\
(0.016)\end{array}$ & $\begin{array}{c}0.121^{* * *} \\
(0.016)\end{array}$ & $\begin{array}{c}0.121^{* * *} \\
(0.016)\end{array}$ \\
\hline Reciprocity: High & $\begin{array}{c}0.110^{* * *} \\
(0.015)\end{array}$ & $\begin{array}{c}0.110^{* * *} \\
(0.015)\end{array}$ & $\begin{array}{c}0.110^{* * *} \\
(0.015)\end{array}$ \\
\hline Altruism: High & $\begin{array}{c}0.096^{* * *} \\
(0.017)\end{array}$ & $\begin{array}{c}0.094^{* * *} \\
(0.017)\end{array}$ & $\begin{array}{c}0.094^{* * *} \\
(0.017)\end{array}$ \\
\hline GHG Emissions: Billion Tons & $\begin{array}{c}-0.135^{* * *} \\
(0.033)\end{array}$ & & \\
\hline $\begin{array}{l}\text { GHG Emissions: Middle } \\
\text { GHG Emissions: High }\end{array}$ & & $\begin{array}{c}-0.016 \\
(0.018) \\
-0.074^{* * *} \\
(0.019)\end{array}$ & \\
\hline GHG Emissions: Lower Middle & & & $\begin{array}{l}-0.017 \\
(0.020)\end{array}$ \\
\hline GHG Emissions: Higher Middle & & & $\begin{array}{c}-0.059^{* * *} \\
(0.022)\end{array}$ \\
\hline GHG Emissions: High & & & $\begin{array}{c}-0.094^{* * *} \\
(0.022)\end{array}$ \\
\hline Germany & $\begin{array}{c}0.058^{* * *} \\
(0.021)\end{array}$ & $\begin{array}{c}0.058^{* * *} \\
(0.021)\end{array}$ & $\begin{array}{c}0.052^{* *} \\
(0.021)\end{array}$ \\
\hline United Kingdom & $\begin{array}{c}-0.079^{* * *} \\
(0.021)\end{array}$ & $\begin{array}{c}-0.078 * * * \\
(0.021)\end{array}$ & $\begin{array}{c}-0.086^{* * *} \\
(0.021)\end{array}$ \\
\hline United States & $\begin{array}{c}-0.214^{* * *} \\
(0.023)\end{array}$ & $\begin{array}{c}-0.241^{* * *} \\
(0.022)\end{array}$ & $\begin{array}{c}-0.254^{* * *} \\
(0.022)\end{array}$ \\
\hline Constant & $\begin{array}{c}0.506^{* * *} \\
(0.036)\end{array}$ & $\begin{array}{c}0.539 * * * \\
(0.037)\end{array}$ & $\begin{array}{c}0.553^{* * *} \\
(0.038)\end{array}$ \\
\hline Observations & 4,008 & 4,008 & 4,008 \\
\hline R-squared & 0.095 & 0.094 & 0.096 \\
\hline
\end{tabular}

Table A-17: Support for Climate Cooperation: Different GHG Emission Indicator Scaling. This table reports OLS regression coefficients and robust standard errors (in parentheses). ${ }^{* * *} p<.01,{ }^{* *} p<.05,{ }^{*} p<.10$. Reference groups are: Sex: Male, Age: 18-29, Income: Low, Education: Low, Reciprocity: Low, Altruism: Low, GHG (CO2 equivalent) Emissions: Low, Employment: Other, Country: France. The sample is employed respondents in France, Germany, the United Kingdom, and the United States. Model 1 employs the raw (continuous) GHG emissions. Model 2 and 3 use indicator variables that distinguish between tertiles and quartiles, respectively. 


\begin{tabular}{|c|c|c|c|}
\hline Dependent Variable & $\begin{array}{c}\text { Support for } \\
\text { Climate Cooperation }\end{array}$ & $\begin{array}{c}\text { Importance of } \mathrm{CO} 2 \\
\text { Reductions }\end{array}$ & $\begin{array}{c}\text { Environment: } \\
\text { Willingness to Pay }\end{array}$ \\
\hline Model & $(1)$ & $(2)$ & $(3)$ \\
\hline \multirow[t]{2}{*}{ Female } & 0.004 & $0.650^{* * *}$ & $1.237^{*}$ \\
\hline & $(0.017)$ & $(0.104)$ & $(0.714)$ \\
\hline \multirow[t]{2}{*}{ Age: $30-39$} & 0.021 & 0.080 & -0.537 \\
\hline & $(0.028)$ & $(0.160)$ & $(1.189)$ \\
\hline \multirow[t]{2}{*}{ Age: $40-49$} & 0.008 & $-0.292^{*}$ & -1.373 \\
\hline & $(0.029)$ & $(0.168)$ & $(1.191)$ \\
\hline \multirow[t]{2}{*}{ Age: $50-59$} & 0.026 & -0.187 & -1.244 \\
\hline & $(0.028)$ & $(0.168)$ & $(1.168)$ \\
\hline \multirow[t]{2}{*}{ Age: $60+$} & 0.009 & -0.281 & -1.213 \\
\hline & $(0.036)$ & $(0.235)$ & $(1.496)$ \\
\hline \multirow[t]{2}{*}{ Income: Lower Middle } & 0.030 & $0.317^{*}$ & 0.020 \\
\hline & $(0.033)$ & $(0.187)$ & $(1.369)$ \\
\hline \multirow[t]{2}{*}{ Income: Middle } & $0.053^{*}$ & $0.303^{*}$ & -0.738 \\
\hline & $(0.031)$ & $(0.178)$ & $(1.252)$ \\
\hline \multirow[t]{2}{*}{ Income: High } & $0.057^{*}$ & 0.029 & -0.783 \\
\hline & $(0.029)$ & $(0.175)$ & $(1.214)$ \\
\hline \multirow[t]{2}{*}{ Education: High } & $0.138^{* * *}$ & $0.370^{* * *}$ & -0.391 \\
\hline & $(0.019)$ & $(0.115)$ & $(0.784)$ \\
\hline \multirow[t]{2}{*}{ Reciprocity: High } & $0.107^{* * *}$ & $0.480^{* * *}$ & $-2.680^{* * *}$ \\
\hline & $(0.017)$ & $(0.106)$ & $(0.746)$ \\
\hline \multirow[t]{2}{*}{ Altruism: High } & $0.098 * * *$ & $0.545^{* * *}$ & $3.486^{* * *}$ \\
\hline & $(0.018)$ & $(0.112)$ & $(0.787)$ \\
\hline \multirow[t]{2}{*}{ GHG Emissions: High } & $-0.079 * * *$ & $-0.473^{* * *}$ & $-2.959 * * *$ \\
\hline & $(0.018)$ & $(0.110)$ & $(0.748)$ \\
\hline \multirow[t]{2}{*}{ United Kingdom } & $-0.094^{* * *}$ & $-0.895^{* * *}$ & $-5.349^{* * *}$ \\
\hline & $(0.021)$ & $(0.113)$ & $(0.924)$ \\
\hline \multirow[t]{2}{*}{ United States } & $-0.256^{* * *}$ & $-1.577^{* * *}$ & $-3.162^{* * *}$ \\
\hline & $(0.022)$ & $(0.135)$ & $(1.002)$ \\
\hline \multirow[t]{2}{*}{ Constant } & $0.540^{* * *}$ & $6.521^{* * *}$ & $22.999 * * *$ \\
\hline & $(0.041)$ & $(0.236)$ & $(1.773)$ \\
\hline Observations & 3,079 & 3,080 & 3,080 \\
\hline R-squared & 0.087 & 0.086 & 0.026 \\
\hline
\end{tabular}

Table A-18: Support for Climate Cooperation: Norms and Interests, Germany excluded). This table reports OLS regression coefficients and robust standard errors (in parentheses). ${ }^{* * *} p<.01,{ }^{* *} p<.05,{ }^{*} p<.10$. Reference groups are: Sex: Male, Age: 18-29, Income: Low, Education: Low, Reciprocity: Low, Altruism: Low, GHG Emissions: Low, Country: France. The sample is employed respondents in the pooled data for France, the United Kingdom, and the United States. 


\begin{tabular}{|c|c|c|c|c|c|c|}
\hline \multirow{2}{*}{$\begin{array}{l}\text { Dependent Variable } \\
\text { Model }\end{array}$} & \multicolumn{4}{|c|}{ Support for Climate Cooperation } & \multirow{2}{*}{$\begin{array}{c}\text { Importance of CO2 } \\
\text { Reductions }\end{array}$} & \multirow{2}{*}{$\begin{array}{c}\text { Environment: } \\
\text { Willingness to Pay } \\
(6)\end{array}$} \\
\hline & $\begin{array}{c}(1) \\
\text { Socio-demographics }\end{array}$ & $\begin{array}{c}(2) \\
\text { Norms }\end{array}$ & $\begin{array}{c}(3) \\
\text { Interest }\end{array}$ & $\begin{array}{c}(4) \\
\text { Full }\end{array}$ & & \\
\hline Female & $\begin{array}{l}-0.001 \\
(0.015)\end{array}$ & $\begin{array}{l}-0.005 \\
(0.015)\end{array}$ & $\begin{array}{l}-0.011 \\
(0.015)\end{array}$ & $\begin{array}{l}-0.014 \\
(0.015)\end{array}$ & $\begin{array}{c}0.587^{* * *} \\
(0.091)\end{array}$ & $\begin{array}{c}1.682^{* * *} \\
(0.631)\end{array}$ \\
\hline Age: $30-39$ & $\begin{array}{l}0.006 \\
(0.026)\end{array}$ & $\begin{array}{c}0.013 \\
(0.026)\end{array}$ & $\begin{array}{c}0.009 \\
(0.026)\end{array}$ & $\begin{array}{c}0.016 \\
(0.026)\end{array}$ & $\begin{array}{c}0.064 \\
(0.146)\end{array}$ & $\begin{array}{c}0.141 \\
(1.063)\end{array}$ \\
\hline Age: $40-49$ & $\begin{array}{l}-0.009 \\
(0.026)\end{array}$ & $\begin{array}{l}0.009 \\
(0.025)\end{array}$ & $\begin{array}{l}-0.003 \\
(0.026)\end{array}$ & $\begin{array}{l}0.015 \\
(0.025)\end{array}$ & $\begin{array}{l}-0.178 \\
(0.151)\end{array}$ & $\begin{array}{l}-0.603 \\
(1.042)\end{array}$ \\
\hline Age: $50-59$ & $\begin{array}{c}0.002 \\
(0.025)\end{array}$ & $\begin{array}{c}0.025 \\
(0.025)\end{array}$ & $\begin{array}{c}0.005 \\
(0.025)\end{array}$ & $\begin{array}{c}0.028 \\
(0.025)\end{array}$ & $\begin{array}{l}-0.067 \\
(0.150)\end{array}$ & $\begin{array}{l}-0.751 \\
(1.020)\end{array}$ \\
\hline Age: $60+$ & $\begin{array}{c}0.002 \\
(0.032)\end{array}$ & $\begin{array}{c}0.023 \\
(0.032)\end{array}$ & $\begin{array}{c}0.005 \\
(0.032)\end{array}$ & $\begin{array}{c}0.025 \\
(0.032)\end{array}$ & $\begin{array}{l}-0.046 \\
(0.199)\end{array}$ & $\begin{array}{l}-1.230 \\
(1.284)\end{array}$ \\
\hline Income: Lower Middle & $\begin{array}{l}0.038 \\
(0.032)\end{array}$ & $\begin{array}{c}0.032 \\
(0.031)\end{array}$ & $\begin{array}{l}0.040 \\
(0.032)\end{array}$ & $\begin{array}{l}0.035 \\
(0.031)\end{array}$ & $\begin{array}{l}0.320^{*} \\
(0.178)\end{array}$ & $\begin{array}{l}0.096 \\
(1.332)\end{array}$ \\
\hline Income: Middle & $\begin{array}{l}0.052^{*} \\
(0.030)\end{array}$ & $\begin{array}{c}0.046 \\
(0.030)\end{array}$ & $\begin{array}{l}0.051^{*} \\
(0.030)\end{array}$ & $\begin{array}{c}0.045 \\
(0.030)\end{array}$ & $\begin{array}{l}0.349^{* *} \\
(0.174)\end{array}$ & $\begin{array}{l}-0.683 \\
(1.252)\end{array}$ \\
\hline Income: High & $\begin{array}{c}0.065^{* *} \\
(0.029)\end{array}$ & $\begin{array}{c}0.057^{* *} \\
(0.029)\end{array}$ & $\begin{array}{c}0.066^{* *} \\
(0.029)\end{array}$ & $\begin{array}{l}0.058^{* *} \\
(0.029)\end{array}$ & $\begin{array}{l}0.030 \\
(0.171)\end{array}$ & $\begin{array}{l}-1.174 \\
(1.206)\end{array}$ \\
\hline Education: High & $\begin{array}{c}0.139^{* * *} \\
(0.017)\end{array}$ & $\begin{array}{c}0.128^{* * *} \\
(0.017)\end{array}$ & $\begin{array}{c}0.128^{* * *} \\
(0.017)\end{array}$ & $\begin{array}{c}0.118^{* * *} \\
(0.017)\end{array}$ & $\begin{array}{c}0.302^{* * *} \\
(0.102)\end{array}$ & $\begin{array}{c}-0.179 \\
(0.706)\end{array}$ \\
\hline Reciprocity: High & & $\begin{array}{c}0.106^{* * *} \\
(0.015)\end{array}$ & & $\begin{array}{c}0.103^{* * *} \\
(0.015)\end{array}$ & $\begin{array}{c}0.536^{* * *} \\
(0.093)\end{array}$ & $\begin{array}{c}-2.649^{* * *} \\
(0.662)\end{array}$ \\
\hline Altruism: High & & $\begin{array}{c}0.098^{* * *} \\
(0.017)\end{array}$ & & $\begin{array}{c}0.097^{* * *} \\
(0.017)\end{array}$ & $\begin{array}{c}0.503^{* * *} \\
(0.104)\end{array}$ & $\begin{array}{c}3.871^{* * *} \\
(0.748)\end{array}$ \\
\hline GHG Emissions: High & & & $\begin{array}{c}-0.076^{* * *} \\
(0.016)\end{array}$ & $\begin{array}{c}-0.070^{* * *} \\
(0.015)\end{array}$ & $\begin{array}{c}-0.401^{* * *} \\
(0.095)\end{array}$ & $\begin{array}{c}-2.263^{* * *} \\
(0.660)\end{array}$ \\
\hline Germany & $\begin{array}{l}0.046^{* *} \\
(0.021)\end{array}$ & $\begin{array}{l}0.058^{* *} \\
(0.021)\end{array}$ & $\begin{array}{l}0.039^{*} \\
(0.022)\end{array}$ & $\begin{array}{c}0.051^{* *} \\
(0.021)\end{array}$ & $\begin{array}{l}-0.025 \\
(0.116)\end{array}$ & $\begin{array}{l}-0.516 \\
(1.001)\end{array}$ \\
\hline United Kingdom & $\begin{array}{c}-0.069^{* * *} \\
(0.022)\end{array}$ & $\begin{array}{c}-0.076^{* * *} \\
(0.021)\end{array}$ & $\begin{array}{c}-0.083^{* * *} \\
(0.022)\end{array}$ & $\begin{array}{c}-0.089 * * * \\
(0.022)\end{array}$ & $\begin{array}{c}-0.898^{* * *} \\
(0.114)\end{array}$ & $\begin{array}{c}-5.153^{* * *} \\
(0.931)\end{array}$ \\
\hline United States & $\begin{array}{c}-0.232^{* * *} \\
(0.023)\end{array}$ & $\begin{array}{c}-0.240 * * * \\
(0.022)\end{array}$ & $\begin{array}{c}-0.242^{* * *} \\
(0.023)\end{array}$ & $\begin{array}{c}-0.249^{* * *} \\
(0.022)\end{array}$ & $\begin{array}{c}-1.548^{* * *} \\
(0.136)\end{array}$ & $\begin{array}{c}-3.137^{* * *} \\
(1.014)\end{array}$ \\
\hline Constant & $\begin{array}{c}0.589^{* * *} \\
(0.036)\end{array}$ & $\begin{array}{c}0.508^{* * *} \\
(0.037)\end{array}$ & $\begin{array}{c}0.637^{* * * *} \\
(0.037)\end{array}$ & $\begin{array}{c}0.555^{* * *} \\
(0.038)\end{array}$ & $\begin{array}{c}6.435^{* * *} \\
(0.223)\end{array}$ & $\begin{array}{c}21.803^{* * *} \\
(1.676)\end{array}$ \\
\hline Observations & 4,008 & 4,008 & 4,008 & 4,008 & 4,009 & 4,009 \\
\hline R-squared & 0.072 & 0.092 & 0.078 & 0.097 & 0.086 & 0.024 \\
\hline
\end{tabular}

Table A-19: Support for Climate Cooperation: Weighted Estimates. This table reports OLS regression coefficients and robust standard errors (in parentheses). ${ }^{* * *} p<.01,{ }^{* *} p<.05$, ${ }^{*} p<.10$. Reference groups are: Sex: Male, Age: 18-29, Income: Low, Education: Low, Reciprocity: Low, Altruism: Low, GHG Emissions: Low, Country: France. The sample is employed respondents in the pooled data for France, Germany, the United Kingdom, and the United States. 


\section{Appendix: Experimental Results}

\section{Conjoint Instructions}

The directions for the conjoint experiment appeared on two pages before the respondent began choosing between agreements. First, respondents were given the following instructions:

Most countries around the world are currently discussing the possibility of agreeing to new policies that would address the problem of global warming. We are interested in what you think about these international efforts and the United States's possible participation in such an agreement.

We will now provide you with several examples of what agreements between countries to address climate change could look like. We will always show you two possible agreements in comparison. For each comparison we would like to know which of the two agreements you prefer. You may like both alternatives similarly or may not like either of them at all. Regardless of your overall evaluation, please indicate which alternative you prefer over the other.

In total, we will show you four comparisons. People have different opinions about this issue and there are no right or wrong answers. Please take your time when reading the potential agreements. In addition to deciding which climate agreement you would prefer, we also ask you how likely you would be to vote for or against the United States joining each agreement in a referendum.

Second, respondents were shown the following screenshot example with further instructions:

Figure A-1 shows the features of the two possible agreements that you will be choosing between. Note that the order of the features may vary. 
Comparison 1: Which agreement do you prefer?

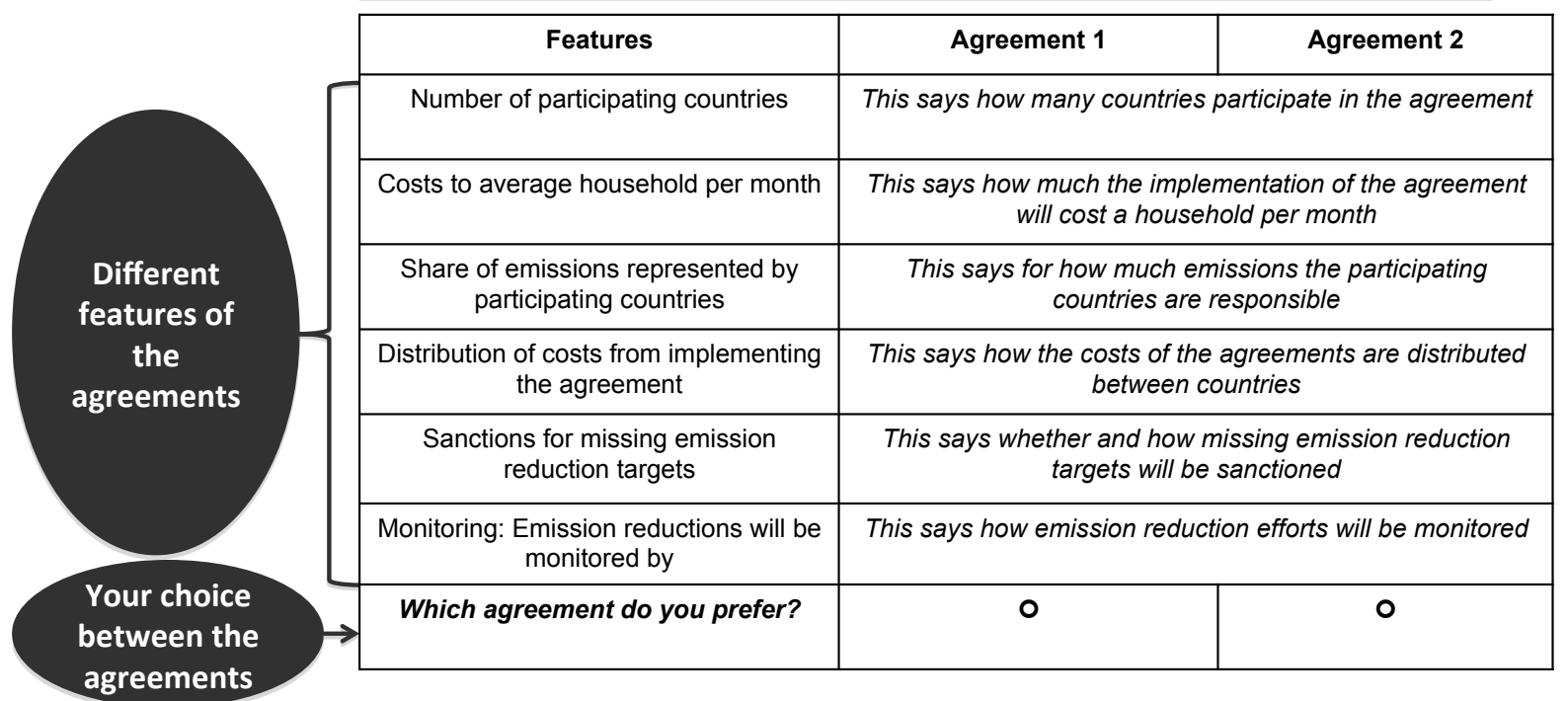

If you could vote on each of these agreements in a referendum, how likely is it that you would vote in favor or against each of the agreements? Please give your answer on the following scale from definitely against (1) to definitely in favor (10).

\begin{tabular}{|c|c|c|c|c|c|c|c|c|c|c|c|}
\hline & & $\begin{array}{c}\text { Vote } \\
\text { definitely } \\
\text { against } \\
1\end{array}$ & 2 & 3 & 4 & 5 & 6 & 7 & 8 & 9 & $\begin{array}{c}\text { Vote } \\
\text { definitely } \\
\text { in favor } \\
10\end{array}$ \\
\hline Your rating & Agreement 1 & 0 & 0 & 0 & 0 & 0 & 0 & 0 & 0 & 0 & 0 \\
\hline Or the & Agreement 2 & 0 & 0 & 0 & 0 & 0 & 0 & 0 & 0 & 0 & 0 \\
\hline
\end{tabular}

Figure A-1: Conjoint Instructions 


\section{Additional Conjoint Results}

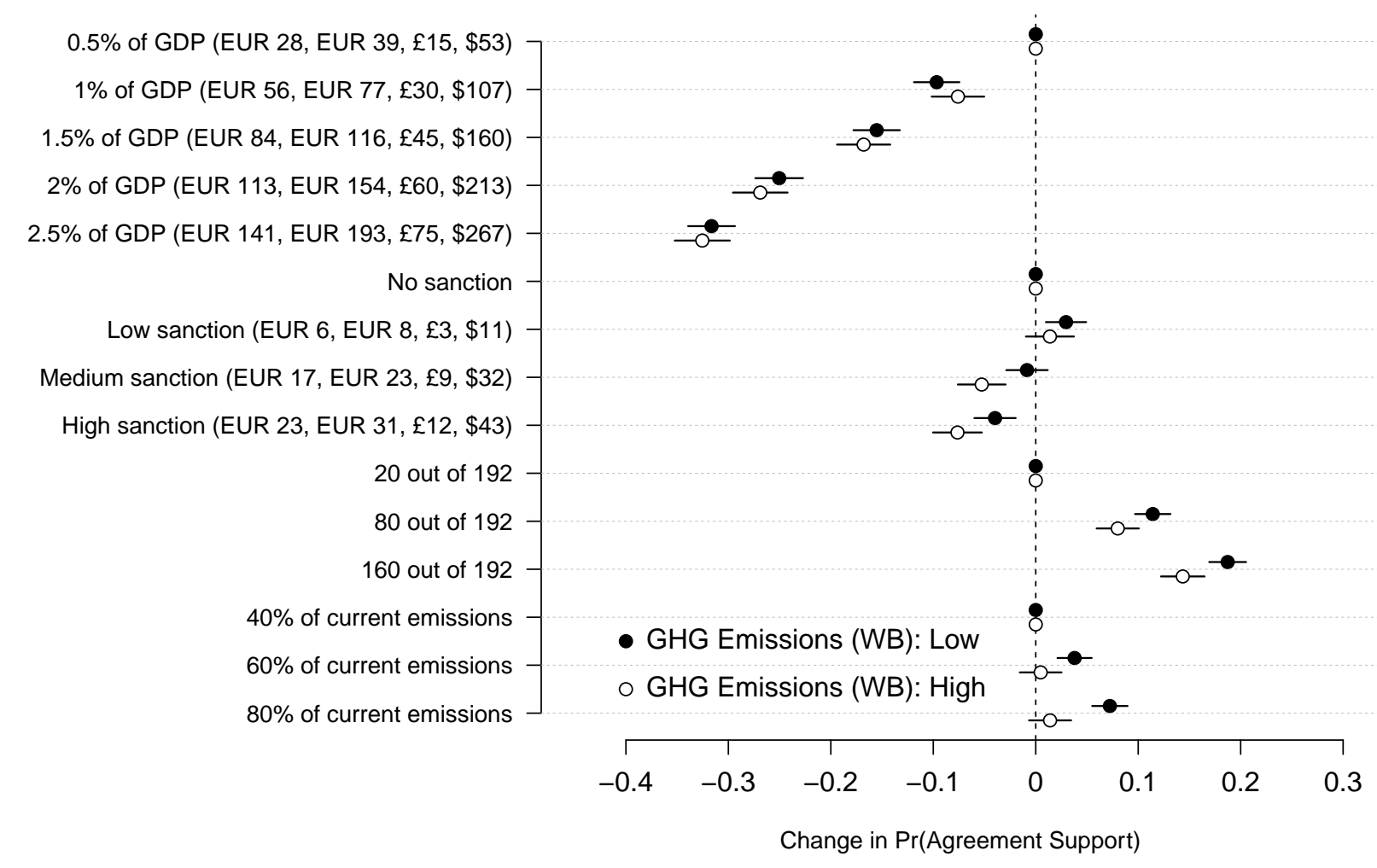

Figure A-2: The Effects of Costs and Participation on Support for Climate Agreements by GHG Emissions (CO2 equivalent, World Bank measure). This plot shows estimates of the effect of randomly assigned agreement features on the probability of supporting an agreement for employed respondents $(N=33,408$ agreements, pooled data for France, Germany, the United Kingdom, and the United States) by CO2-equivalent emissions of respondents' sector of employment. Estimates are based on the regression of Agreement Support on dummy variables for values of the agreement dimensions, with SEs clustered by respondent. The bars indicate $95 \%$ confidence intervals based on robust standard errors clustered by respondent. Points without bars indicate the reference category for a given agreement dimension. 


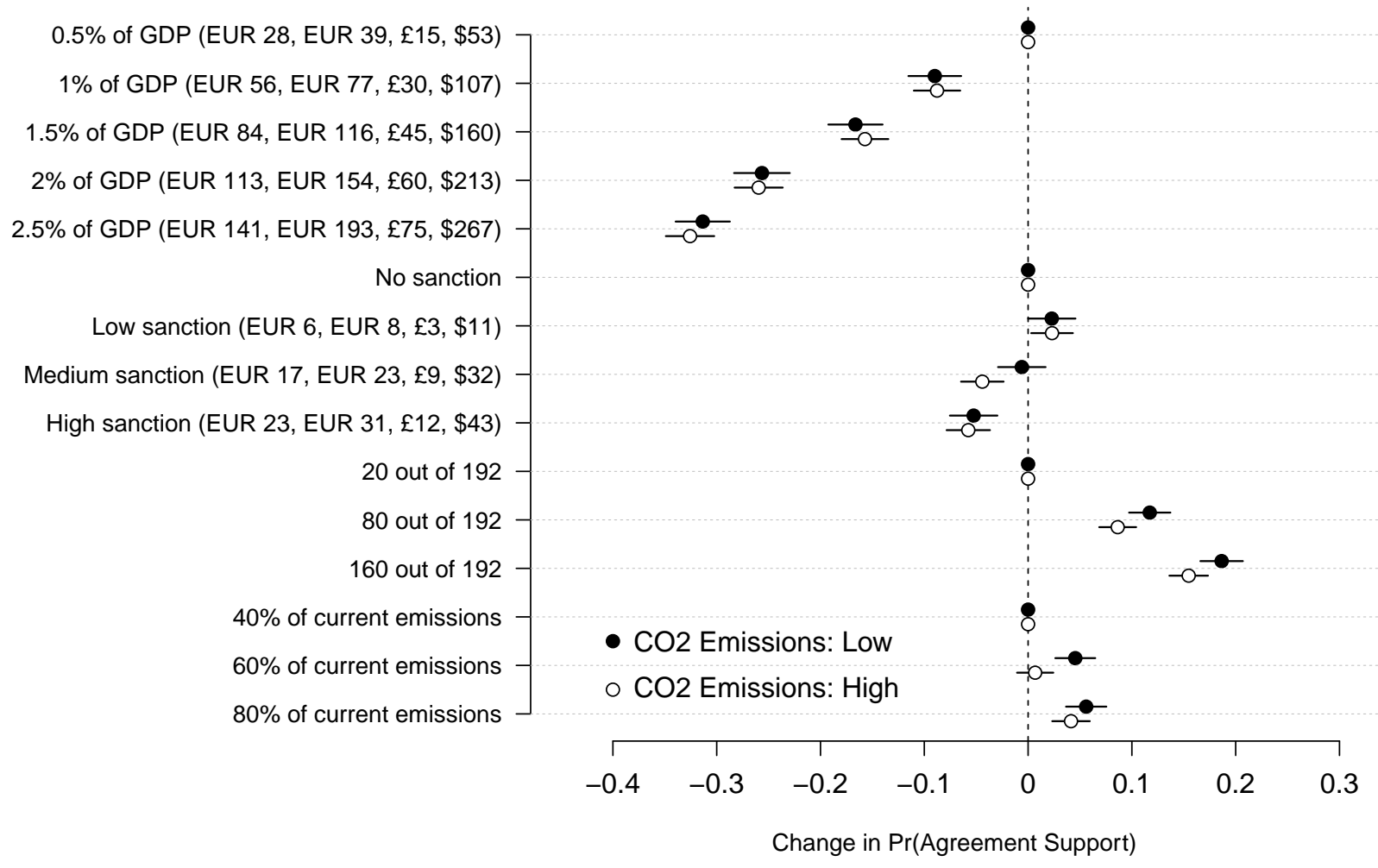

Figure A-3: The Effects of Costs and Participation on Support for Climate Agreements by CO2-only Emissions. This plot shows estimates of the effect of randomly assigned agreement features on the probability of supporting an agreement for employed respondents $(N=$ 33, 408 agreements, pooled data for France, Germany, the United Kingdom, and the United States) by CO2-only emissions of respondents' sector of employment. Estimates are based on the regression of Agreement Support on dummy variables for values of the agreement dimensions, with SEs clustered by respondent. The bars indicate $95 \%$ confidence intervals based on robust standard errors clustered by respondent. Points without bars indicate the reference category for a given agreement dimension. 


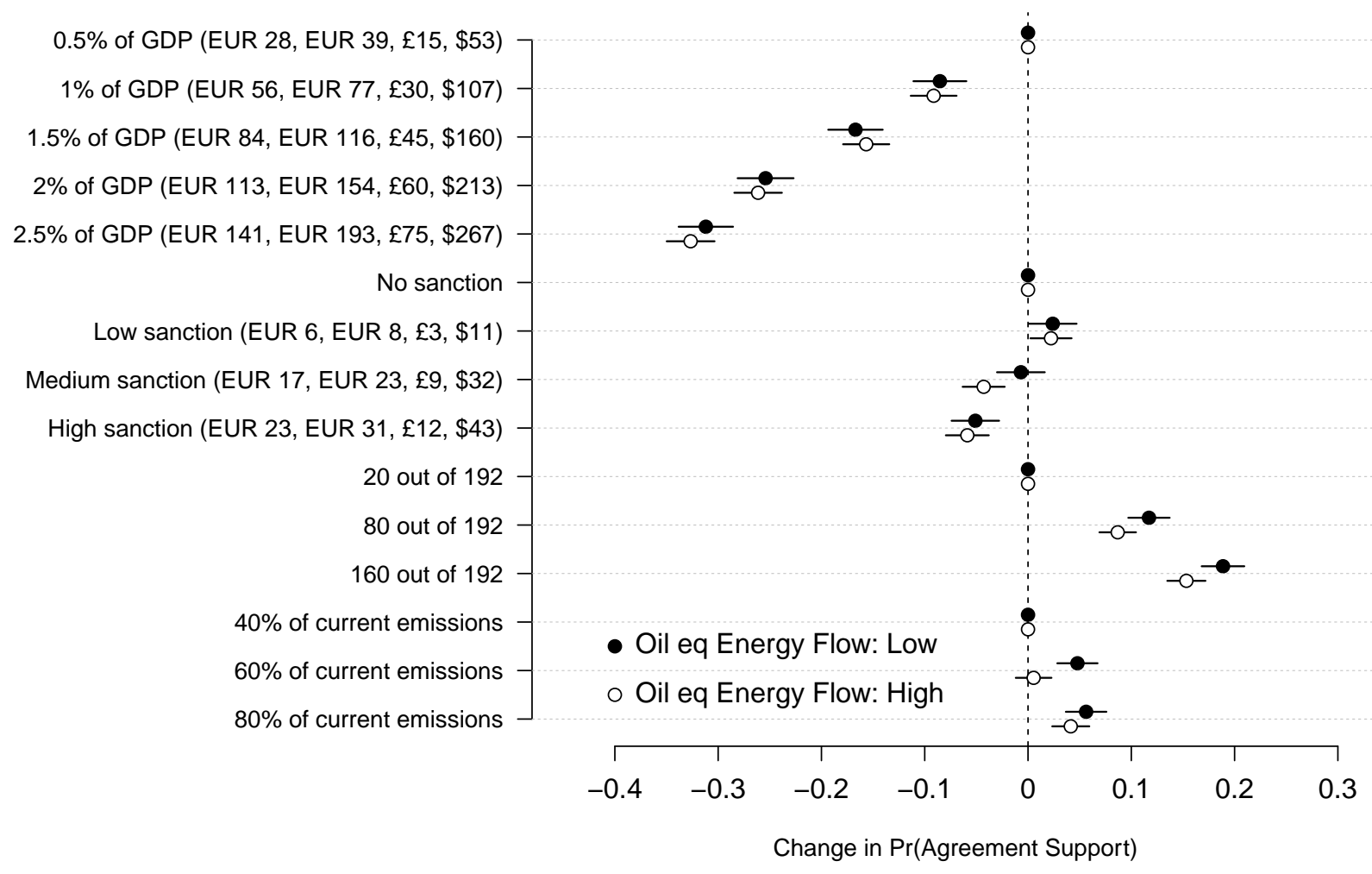

Figure A-4: The Effects of Costs and Participation on Support for Climate Agreements by Oil-equivalent Energy Flows. This plot shows estimates of the effect of randomly assigned agreement features on the probability of supporting an agreement for employed respondents ( $N=33,408$ agreements, pooled data for France, Germany, the United Kingdom, and the United States) by net energy transfers of respondents' sector of employment. Estimates are based on the regression of Agreement Support on dummy variables for values of the agreement dimensions, with SEs clustered by respondent. The bars indicate $95 \%$ confidence intervals based on robust standard errors clustered by respondent. Points without bars indicate the reference category for a given agreement dimension. 


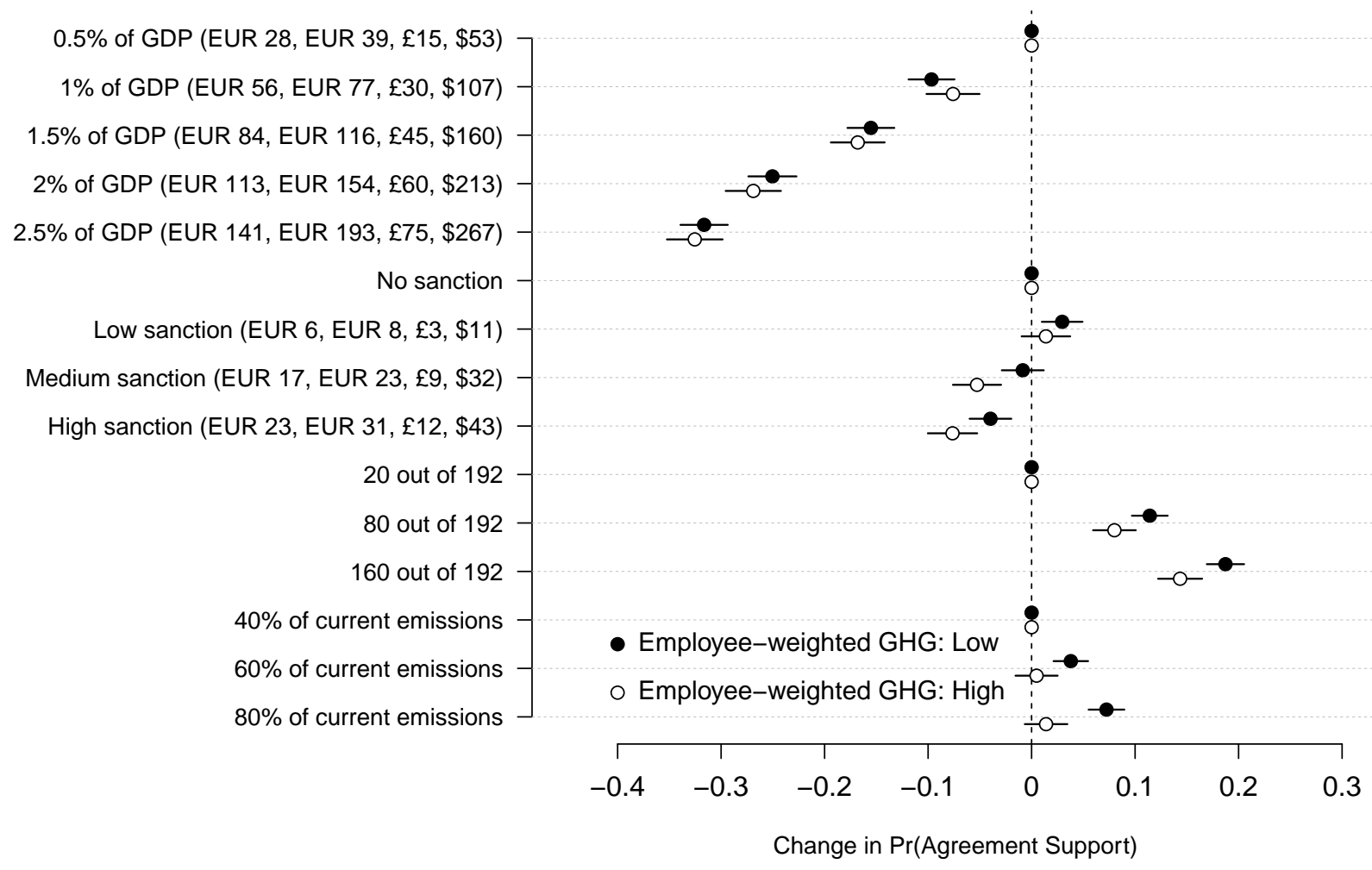

Figure A-5: The Effects of Costs and Participation on Support for Climate Agreements by Employee-weighted GHG Emissions. This plot shows estimates of the effect of randomly assigned agreement features on the probability of supporting an agreement $(N=33,408$ agreements, pooled data for France, Germany, the United Kingdom, and the United States) by employee-weighted GHG (CO2-equivalent) emissions of respondents' sector of employment. Estimates are based on the regression of Agreement Support on dummy variables for values of the agreement dimensions, with SEs clustered by respondent. The bars indicate $95 \%$ confidence intervals based on robust standard errors clustered by respondent. Points without bars indicate the reference category for a given agreement dimension. 


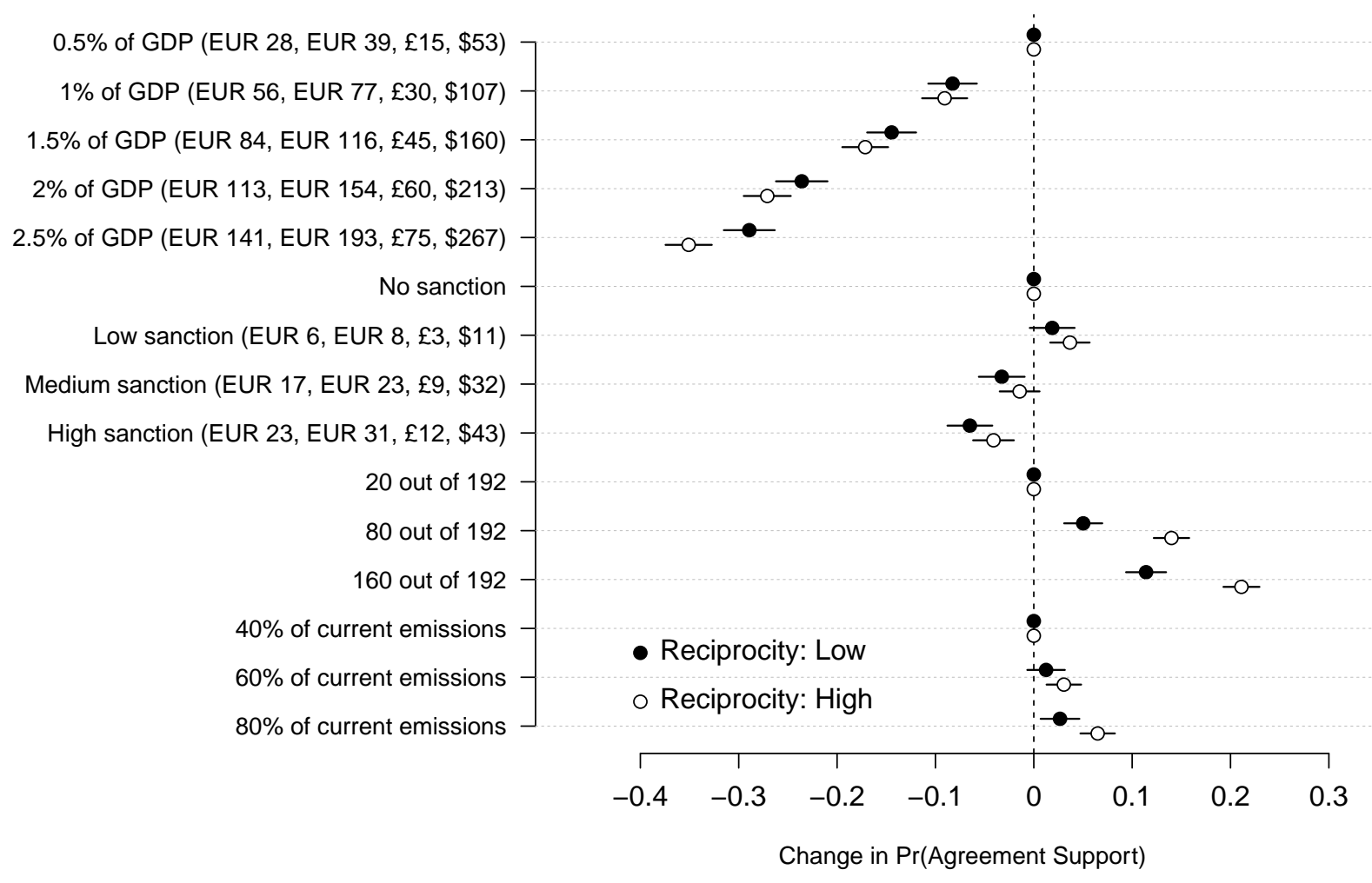

Figure A-6: The Effects of Costs and Participation on Support for Climate Agreements by Level of Reciprocity. This plot shows estimates of the effect of randomly assigned agreement features on the probability of supporting an agreement $(N=68,000$ agreements, pooled data for France, Germany, the United Kingdom, and the United States) by respondents' level of reciprocity. Estimates are based on the regression of Agreement Support on dummy variables for values of the agreement dimensions, with SEs clustered by respondent. The bars indicate $95 \%$ confidence intervals based on robust standard errors clustered by respondent. Points without bars indicate the reference category for a given agreement dimension. 


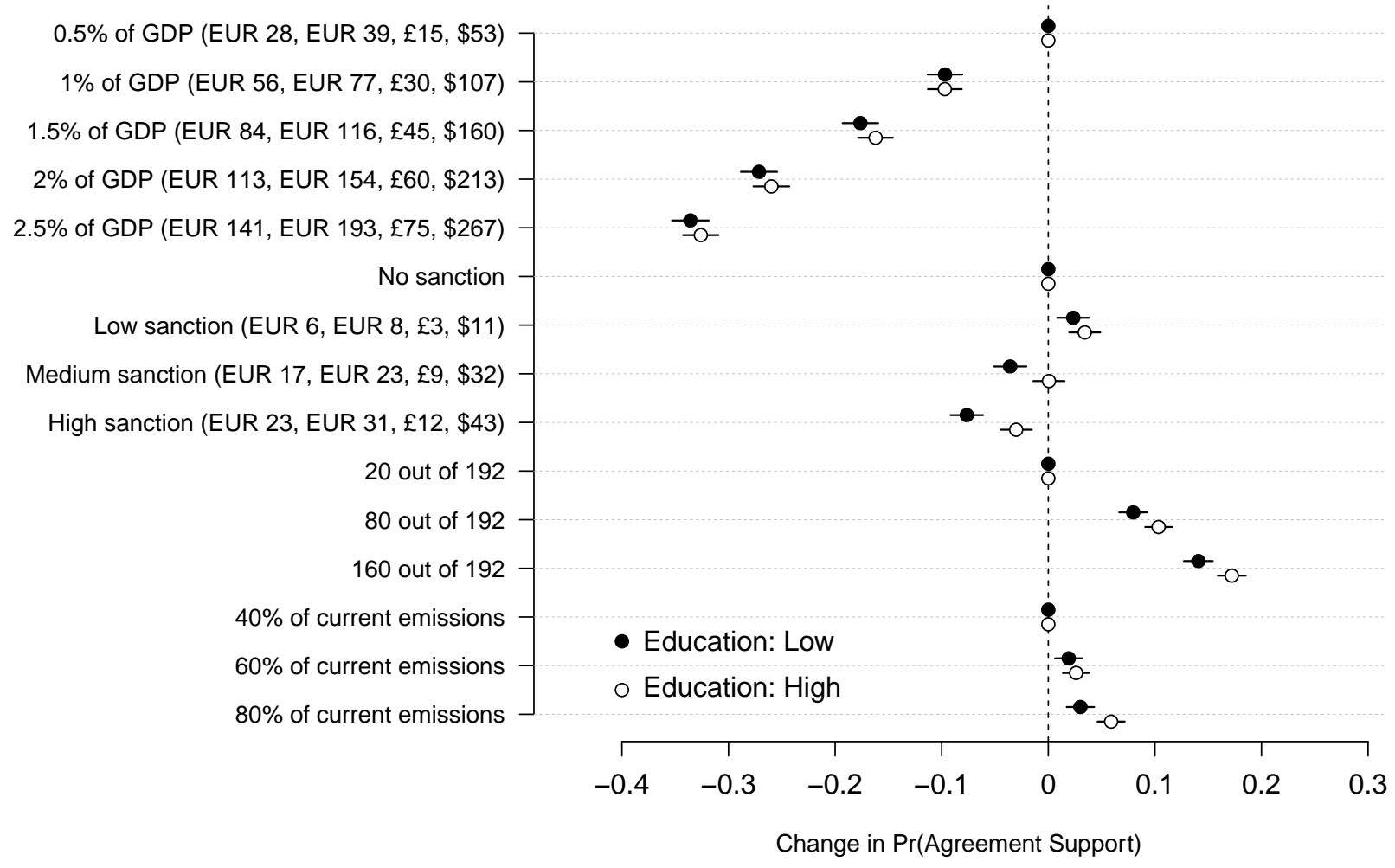

Figure A-7: The Effects of Costs and Participation on Support for Climate Agreements by Level of Education. This plot shows estimates of the effect of randomly assigned agreement features on the probability of supporting an agreement $(N=68,000$ agreements, pooled data for France, Germany, the United Kingdom, and the United States) by respondents' level of education attainment. Estimates are based on the regression of Agreement Support on dummy variables for values of the agreement dimensions, with SEs clustered by respondent. The bars indicate $95 \%$ confidence intervals based on robust standard errors clustered by respondent. Points without bars indicate the reference category for a given agreement dimension. 
France

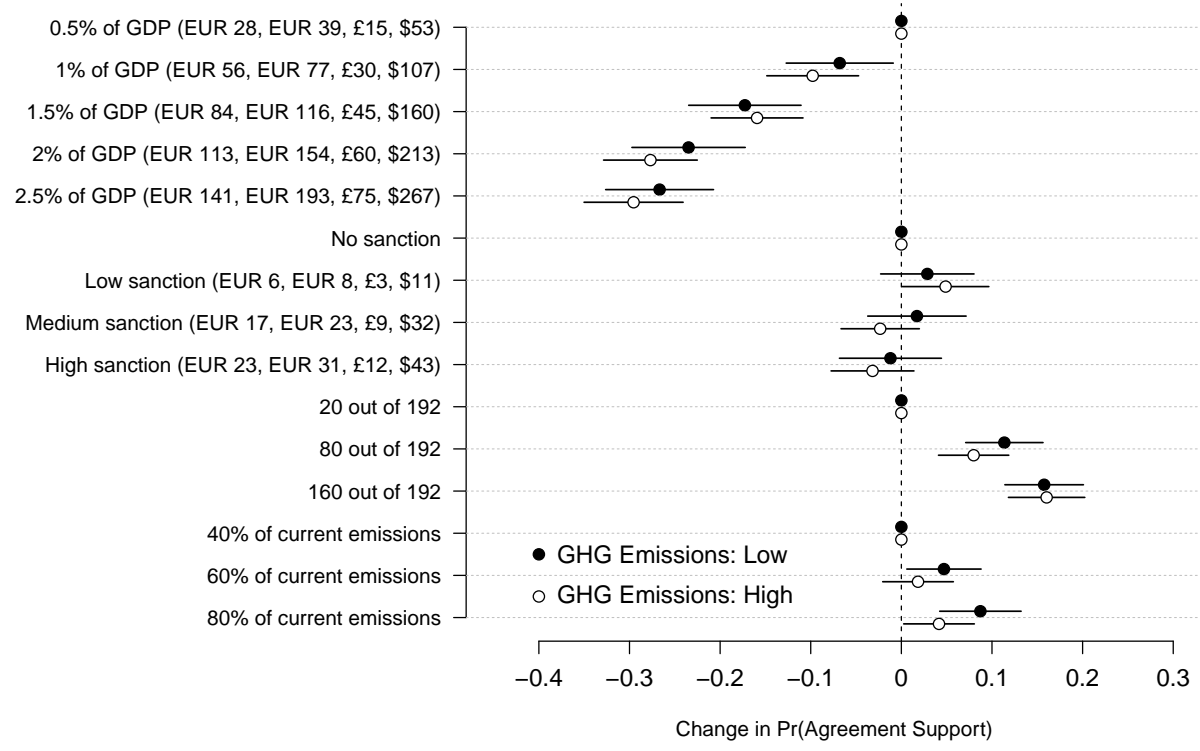

United Kingdom

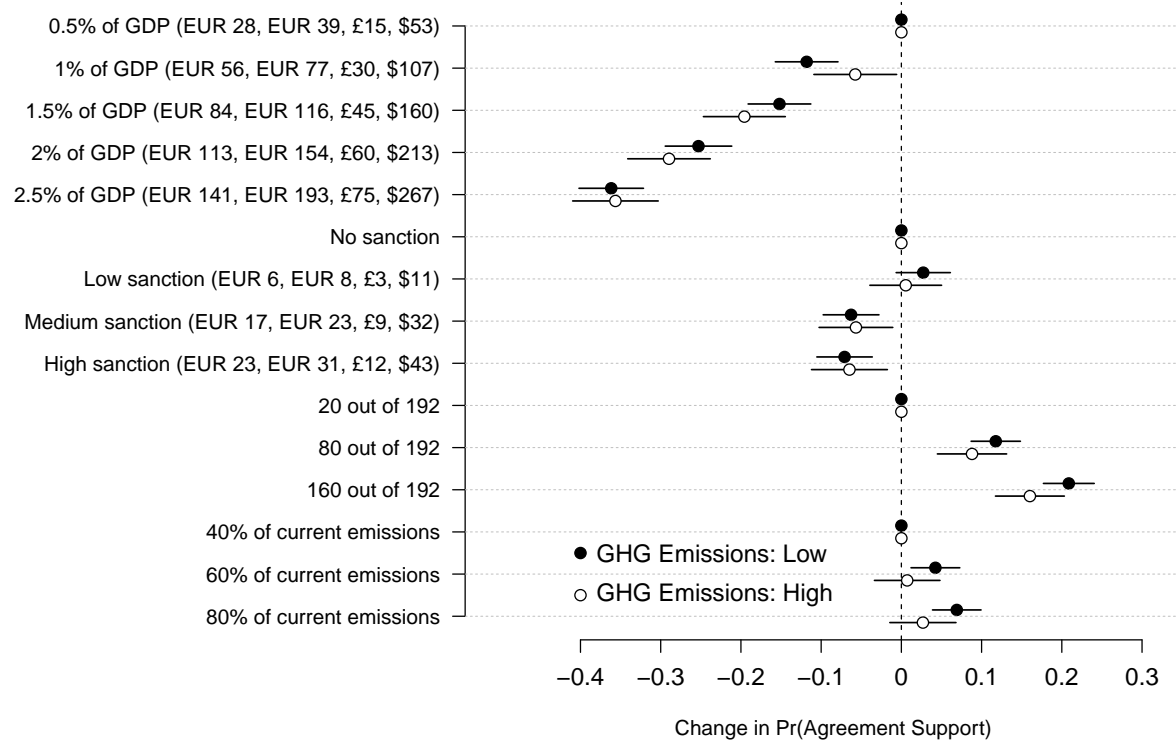

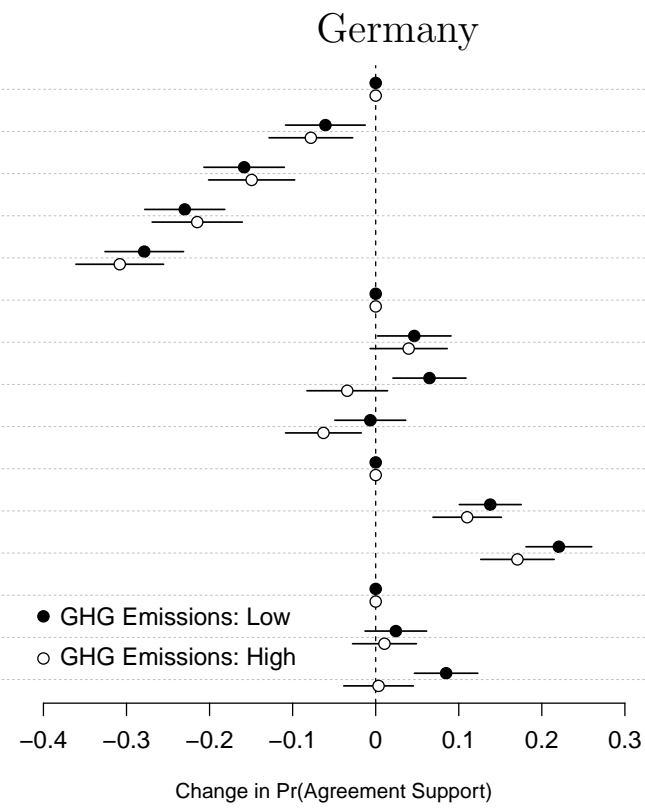

United States

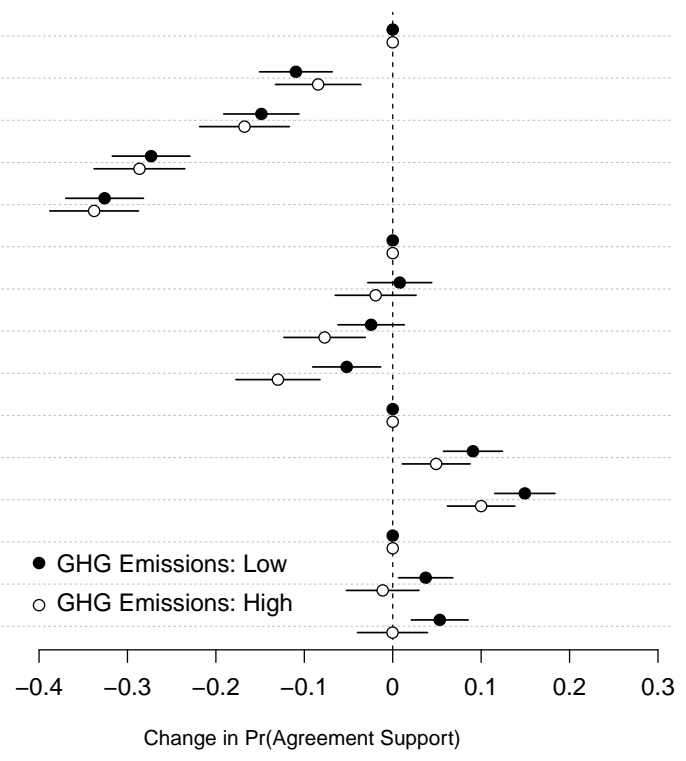

Figure A-8: The Effects of Costs and Participation on Support for Climate Agreements by GHG (CO2 equivalent) Emissions by Country. This plot shows estimates of the effect of randomly assigned agreement features on the probability of supporting an agreement for employed respondents in each country subset. Estimates are based on the regression of Agreement Support on dummy variables for values of the agreement dimensions, with SEs clustered by respondent. The bars indicate $95 \%$ confidence intervals based on robust standard errors clustered by respondent. Points without bars indicate the reference category for a given agreement dimension. 